cyp.

GEAP- 10355

AEC RESEARCH AND

DEVELOPMENT REPORT

APRIL 1971

\title{
DESIGN AND FABRICATION OF SPECIAL ASSEMBLY SA-1
}

Compiled by

F. H. MEGERTH

U. S. ATOMIC ENERGY COMMISSION

CONTRACT AT(04-3)-189

PROJECT AGREEMENT 41 


\section{DISCLAIMER}

This report was prepared as an account of work sponsored by an agency of the United States Government. Neither the United States Government nor any agency Thereof, nor any of their employees, makes any warranty, express or implied, or assumes any legal liability or responsibility for the accuracy, completeness, or usefulness of any information, apparatus, product, or process disclosed, or represents that its use would not infringe privately owned rights. Reference herein to any specific commercial product, process, or service by trade name, trademark, manufacturer, or otherwise does not necessarily constitute or imply its endorsement, recommendation, or favoring by the United States Government or any agency thereof. The views and opinions of authors expressed herein do not necessarily state or reflect those of the United States Government or any agency thereof. 


\section{DISCLAIMER}

Portions of this document may be illegible in electronic image products. Images are produced from the best available original document. 
This report was prepared as an account of work snonsored by the United States Government. Neither the United States nor the United States Atomic Fnergy their contractors, subcontractors, or their employees, their contry warranty, express or implied, or assumes any legal liability or responsibility for the accuracy, completeness or usefulness of any information, apparatus, product or process disclosed, or represents that its use would not infringe privately owned rights.

\section{DESIGN AND FABRICATION OF SPECIAL ASSEMBLY SA-1}

Compiled by

F. H. Megerth

Approved:

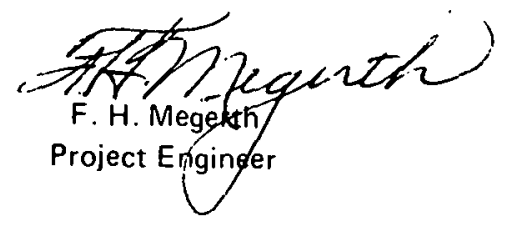

Approved:

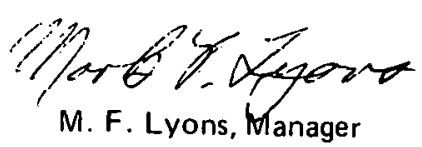

Fuel Development Water Reactors

Prepared for the

U. S. Atomic Energy Commission Under Contract Number AT (04-3)-189

Project Agreement 41 


\section{NOTICE}

This report was prepared as an account of work sponsored by the United States Government. Neither the United States nor the United States Atomic Energy Com. mission, nor any of their employees, nor any of their contractors, subcontractors. or their employees, makes any warranty, express or implied, or assumes any legal liability or responsibility for the accuracy. completeness or usefulness of any infor. mation, apparatus, product or. process disclosed, or represents that: its use would not infringe privately owned rights.. 


\section{TABLE OF CONTENTS}

1. Introduction . . . . . . . . . . . . . . . . . . . . . . . . . . . . 1

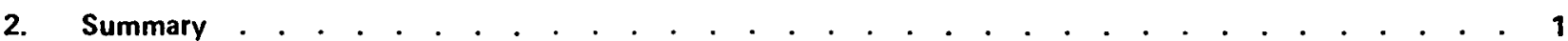

3. Description of Fuel Assembly . . . . . . . . . . . . . . . . . . . . . . . . . . 2

4. Fuel Rod Design. . . . . . . . . . . . . . . . . . . . . . . . . . . . . . . 2

4.1 Cladding Thickness . . . . . . . . . . . . . . . . . . . . . . . . . . . . . . . . 2

4.2 Fission Gas Release . . . . . . . . . . . . . . . . . . . . . . . . . . . . . . . 9

4.3 Cladding Strength . . . . . . . . . . . . . . . . . . . . . . . . . . . . . . . . 9

๖. Fuel fabrication . . . . . . . . . . . . . . . . . . . . . . . . . . . . . . g

5.1 Tubing Processing . . . . . . . . . . . . . . . . . . . . . . . . . . . . . . . . . . . 9

5.2 End Plug Processing. . . . . . . . . . . . . . . . . . . . . . . . . . . 15

5.3 Uranium Dioxide Processing . . . . . . . . . . . . . . . . . . . . . . . . 16

5.4 Rod Fabrication . . . . . . . . . . . . . . . . . . . . . . . . . . . . 22

6. Leak Testing and Examination of the Type J Fuel after VBWR Operation . . . . . . . . . . . . . . 28

7. Rod Selection and Assembly Procedure . . . . . . . . . . . . . . . . . . . . . . . 31

8. Operational Characteristics of the Assembly : . . . . . . . . . . . . . . . . . . . . . 35

\section{APPENDICES}

Appendix A

Appendix B . . . . . . . . . . . . . . . . . . . . . . . . . . . . . . . . 49

Appendix C . . . . . . . . . . . . . . . . . . . . . . . . . . . . . . . 57

References. . . . . . . . . . . . . . . . . . . . . . . . . . . . . . 59

Acknowledgments . . . . . . . . . . . . . . . . . . . . . . . . . . . . . . 59

Distribution . . . . . . . . . . . . . . . ..................61 61 


\section{LIST OF ILLUSTRATIONS}

Figure

Title

Page

1 Assembly \$A-1

SA-1 Subassembly

3 Bottom of Subassembly 3 . . . . . . . . . . . . . . . . . . . . . . . . . . . . . . . . . . . . . 5

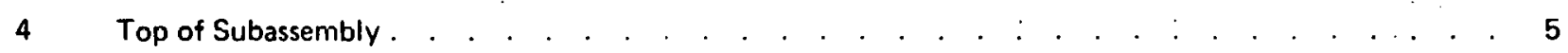

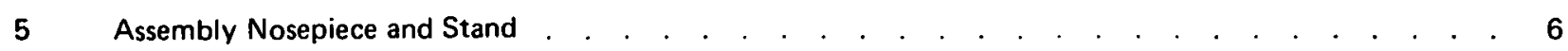

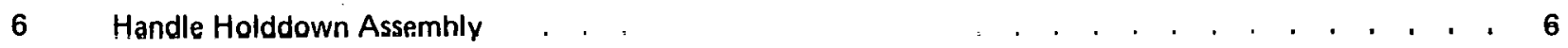

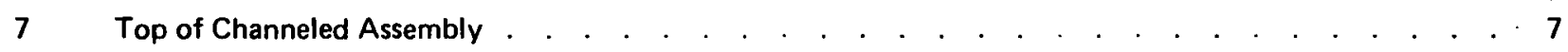

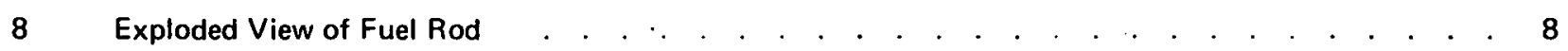

9 Maximum Cladding Stresses as a Function of Burnup . . . . . . . . . . . . . . . . . . . . . . . . . . . . 10

10 Hydride Distribution and Grain Size Determination in Transverse and Longitudinal Tubing Sections . . 14

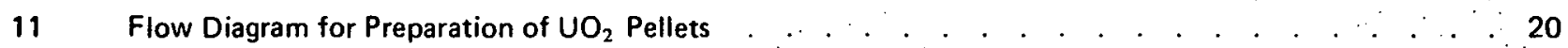

12 Maximum Sizes of Chips Allowed in Finished Pellets . . . . . . . . . . . . . . . . . . . . . . . . . . 26

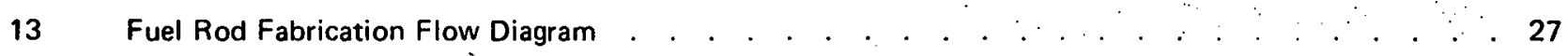

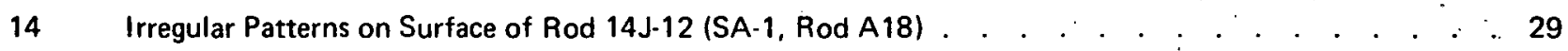

15 Severe Fretting Wear at Single-Layer Wire Spacer Contacts . . . . . . . . . . . . . . . . . . . . . 30

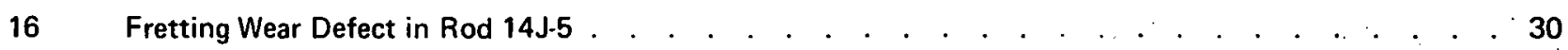

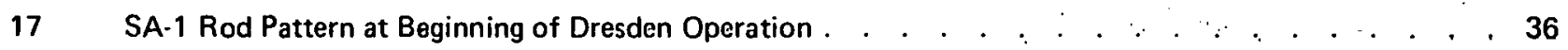

18 Relative Radial Powers for Various Subassembly Rod Locations in Assembly SA-1 . . . . . . . . 37

19 Coolant Mass Flux as a Function of Assembly Power . . . . . . . . . . . . . . . . . . . . . 39

20 Fuel Centerline Temperature Versus Circumferential-Average Rod Surface Heat Flux . . . . . . . . . 39

A-1 Fuel Bundle . . . . . . . . . . . . . . . . . . . . . . . . . . . . . . . . . . . . . . . . . 42

A-2 Fuel Rod . . . . . . . . . . . . . . . . . . . . . . . . . . . . . . . . . . . . . . . . . . . . 43

A.3 End Plug . . . . . . . . . . . . . . . . . . . . . . . . . . . . . . . . . . . . . . . . . . . . . .

A-4 Tube . . . . . . . . . . . . . . . . . . . . . . . . . . . . . . . . . . . 45

A-5 Support . . . . . . . . . . . . . . . . . . . . . . . . . . . . . . . . . . . . . . . . . . . . 46 


\section{LIST OF ILLUSTRATIONS (Continued)}

A.6 Wafer . . . . . . . . . . . . . . . . . . . . . . . . . . 46

A.7 End Plug . . . . . . . . . . . . . . . . . . . . . . . . . . . . . . . . 47

A-8 Fuel Pellet . . . . . . . . . . . . . . . . . . . . . . . . . . . . . 48

B-1 Inside Diameter Measurements on Sample Tubes From Lot CA-1 . . . . . . . . . . . . . . . 49

B-2 Wall Thickness Measurements on Sample Tubes From Lot CA-1 . . . . . . . . . . . . . . . . 50

B-3 Difference in Maximum and Minimum Wall Thickness Measurements on Individual Sample Tubes

From Lot CA-1 . . . . . . . . . . . . . . . . . . . . . . . . . . . . . . 50

B-4 Inside Diameter Measurements on Sample Tubes From Lot CA-2 . . . . . . . . . . . . . . . 51

B-5 Wall Thickness Measurements on Sample Tubes From Lot CA-2 . . . . . . . . . . . . . . . . . 51

B-6 Difference in Maximum and Minimum Wall Thickness Measurements on Individual Sample Tubes

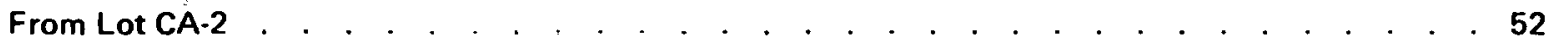

B-7 Inside Diameter Measurements on Sample Tubes From Lot CA-3 . . . . . . . . . . . . . . . . 52

B-8 Wall Thickness Measurements on Sample Tubes From Lot CA-3 . . . . . . . . . . . . . . . 53

B-9 Difference in Maximum and Minimum Wall Thickness Measurements on Individual Sample Tubes

Frngm I nt C.A.3. . . . . . . . : . . . . . . . . . . . . . . . . . . . . . 53

B-10 Inside Diameter Measurements on Sample Tubes From Lot CA-4 . . . . . . . . . . . . . . 54

B-11 Wall Thickness Measurements on Sample Tubes From Lot CA-4 . . . . . . . . . . . . . . . . 54

B-12 Difference in Maximum and Minimum Wall Thickness Measurements on Individual Sample Tubes
From Lot CA-4. . . . . . . . . . . . . . . . . . . . . . . . . 55

B-13 Inside Diameter Measuremèntś on Sample Tubes From Lot CA-5 . . . . . . . . . . . . . . . 55

B-14 Wall Thickness Measurements on Sample Tubes From Lot CA-5 . . . . . . . . . . . . . . 56

B-15 Difference in Maximum and Minimum Wall Thickness Meașurements on Individual Sample Tubes

From Lot CA-5 . . . . . . . . . . . . . . . . . . . . . . . . . . . . . . 56 
GEAP. 10355

\section{LIST OF TABLES}

Table

Title

Page

1 Characteristics of Type J Fuel Rods Selected for Assembly SA-1 . . . . . . . . . . . . . . . . . . . 3

2 Mechanical Properties Tests on Tubing Samples . . . . . . . . . . . . . . . . . . . . . 12

3 Tubing Corrosion Tests . . . . . . . . . . . . . . . . . . . . . . . . . . . . 12

4 Chemical Analysis of Tubing . . . . . . . . . . . . . . . . . . . . . . . . . . . 13

5 Mechanical Properties, Chemical Analysis, and Corrosion Properties of End Plug Material . . . . . . 17

6 Analysis of $\mathrm{UO}_{2}$ Powder and Pellets . . . . . . . . . . . . . . . . . . . . . . . . . . . . . . 18

I Pellet Density and Moisture Ảnalysis . . . . . . . . . . . . . . . . . . . . . . . 21

8 Pre-Irradiation Data on SA-1 Fuel Rods . . . . . . . . . . . . . . . . . . . . . . . . 23

9 Fuel Rod Fabrication Statistics . . . . . . . . . . . . . . . . . . . . . . . . . . . . . . . . . 28

10 Inspection of SA-1 Rods Between VBWR and Dresden Operation . . . . . . . . . . . . . . . . 32

C Diameters of Individually Measured Pellets in Six Rods According to Fuel Column Position . . . . . 57 


\section{INTRODUCTION}

At the time of the final shutdown of the Vallecitos Boiling Water Reactor (VBWR) and the termination of the AEC Fuel Cycle Program [Contract AT(04-3)-189, Project Agreement 11] the leading Zircaloy-2-clad, UO $\mathrm{O}_{2}$ fuel rods of the program's Type $J$ basic assemblies had attained rod-average exposures as high as $3 \times 10^{20} \mathrm{fissions} / \mathrm{cm}^{3}$ $(10,000 \mathrm{MWd} / \mathrm{tU})$ in up to 378 days of operation. To demonstrate at the earliest possible time the capability of Zircaloy-clad fuel to achieve average burnups of at least $6 \times 10^{20}$ fissions $/ \mathrm{cm}^{3}(20,000 \mathrm{MWd} / \mathrm{tU})$ and to take advantage of the available lead time in achieving these burnup targets, 98 of the higher exposure Fuel Cycle Program rods were incorporated in a special assembly, designated SA-1, and inserted in the Dresden Reactor Unit No. 1 for additional irradiation under Project Agreement 41.

The fuel rods in the assembly were designed in 1960 and 1961, and fabricated in 1961 under the Fuel Cycle Program. The bases of the design and fabrication processes are those that were in use for the production of commercial power reactor $\mathrm{UO}_{2}$ pellet filled rod fuel at that time. However, these rods are still generally representative of commercial power reactor fuel being produced. The rest of the assembly was designed and fabricated during the first quarter of 1964 under a General Electric-sponsored project.

Assembly SA-1 operated continuously in Dresden from June 9, 1964, to September 5, 1969, with the exceptions of reactor shutdowns for refueling and maintenance. The details of operation and the results of interim and terminal examinations of the fuel have been presented in a series of progress reports and will be summarized in a final report.

The purpose of the present report is to compile in a single document the pertinent information on the design and fabrication of SA-1 and, thus, facilitate the evaluation of the assembly's performance. Large portions of Sections 4 and 5 on fuel rod design and fabrication were taken from GEAP-3653. "Design and Fabrication of the Basic Fuel Assemblies," by C. J. Baroch, J. P. Hoffmann, and W. C. Rous,' while Section 6 on the post-irradiation leak testing and examination of the VBWR fuel was to a large extent directly extracted from GEAP.4597, "AEC Fuel Cycle Program - Examination of Zircaloy-Clad $\mathrm{UO}_{2}$ Fuel Rods Operated in the VBWR to 10,000 MWd/tU," by H. E. Williamson, C. J. Baroch, J. P. Hoffmann, and D. T. Ikeuye. ${ }^{2}$

\section{SUMMARY}

Assembly SA-1 consisted of two 7 by 7 array subassemblies stacked one on top of the other in a channel of standard dimensions for the Dresden Reactor. The fuel rods consisted of sintered $\mathrm{UO}_{2}$ pellets clad.with annealed Zircaloy-2 tubing. The nominal o.d. and wall thickness of the tubing, which was designed to be "free-standing," were $1.077 \mathrm{~cm}(0.424 \mathrm{in}$.$) and 0.056 \mathrm{~cm}(0.022 \mathrm{in.})$, respectively. The nominal pellet-to-cladding gap was $0.010 \mathrm{~cm}$ (0.004 in.). The overall rod length was $103.4 \mathrm{~cm}(40.7 \mathrm{in.})$.

The seamless tubing was fabricated by the cold drawing process. The inside and outside surfaces of the tubes were pre-filmed with oxide by autoclaving them in $105 \mathrm{~kg} / \mathrm{cm}^{2}(1500 \mathrm{psi}), 399^{\circ} \mathrm{C}\left(760^{\circ} \mathrm{F}\right)$ steam for 36 hours.

The cylindrical pellets were made from ceramic grade $\mathrm{UO}_{2}$ powder produced from $\mathrm{UF}_{6}$ by the ammonium diuranate method. The powder was cold pressed with a wax binder into green compacts. The green pellets were heated to $450^{\circ} \mathrm{C}$ in a hydrogen atmosphere to remove the binder through volatilization and then sintered at $1550^{\circ} \mathrm{C}$ in a hydrogen atmosphere. The sintered pellets were centerless ground to the desired diameter.

The ends of the tubes were sealed with Zircaloy-2 plugs, which were welded to the tubes in a closed chamber that contained a helium atmosphere.

Nearly 400 fuel rods of the above description were assembled into 4 by 4 array bundles and irradiated in the VBWR under the Fuel Cycle Program. At the conclusion of the VBWR operation, 98 rods were carefully selected from this group for further irradiation in Assembly SA-1. In the rod selection process, burnup, residual fissile content, post-VBWR-irradiation ultrasonic testing results, severity of fretting wear, and general visual appearance were taken into account. The rod-average burnups ranged from $1.3 \times 10^{20}$ to $2.6 \times 10^{20}$ fissions $/ \mathrm{cm}^{3}(4800$ to $9500 \mathrm{MWd} / \mathrm{tU})$ and had a mean value of $1.9 \times 10^{20}$ fissions $/ \mathrm{cm}^{3}(7100 \mathrm{MWd} / \mathrm{tU})$. Some of the rods had operated at peak heat fluxes up to about $140 \mathrm{~W} / \mathrm{cm}^{2}\left(440,000 \mathrm{Btu} / \mathrm{h} \cdot \mathrm{ft}^{2}\right.$ or $\left.14 \mathrm{~kW} / \mathrm{ft}\right)$ in the VBWR.

The 98 fuel rods were inserted into two specially fabricated stainless steel subassembly structures and transported to Dresden. Assembly of SA-1 was completed by loading the two bundles into a special stainless steel channel structure at the reactor site. 


\section{DESCRIPTION OF FUEL ASSEMBLY}

Assembly SA-1 consisted of two $7 \times 7,105 \cdot \mathrm{cm}$ (41-1/4 in.) long, subassemblies stacked one on top of the other in a channel of standard dimensions for the Dresden reactor. A sketch of the assembly viewed with a side of the channel removed is shown in Figure 1 . One of the subassemblies is shown before irradiation with a load of dummy fuel rods in Figure 2. A removable lifting tool, partially in view, is attached to the top. The rods in each subassembly rested on a bottom grid, as shown in Figure 3, and were held in position by four spring-type spacers distributed axially along the length of the fuel. The fuel rod pitch was $1.511 \mathrm{~cm}(0.595 \mathrm{in}$.$) .$

The spacers were supported by corner angles which were attached to the bottom grid and extended the full length of the subassembly, to form an integral basket for the fuel rods. The corner angles were fastened at the top to a band which extended about $0.6 \mathrm{~cm}$ (1/4 in.) above the top of the fuel rods (see Figure 4 ). A design drawing of a subassembly is shown in Appendix A (Figure A-1).

The first subassembly was supported by a stand attached to a standard Dresden assembly nosepiece with a partially cut out grid (see Figure 5). The second subassembly rested on the first. The fission gas plenums of the rods in the bottom subassembly were pointed toward the bottom grid, and those of the rods in the top subassembly were pointed toward the top band.

The SA.1 fuel column was approximately $192 \mathrm{~cm}(75-9 / 16 \mathrm{in.})$ long, which included an approximate $3 \mathrm{~cm}$ ( 1-1/4 in.) nonfueled gap between the subassemblies. The bottom of the total fuel column was $58.6 \mathrm{~cm}(23-1 / 16 \mathrm{in}$.) above the bottom of the reactor active fuel zone and the top of the column was $28.7 \pm 4.4 \mathrm{~cm} \mathrm{(11-5/16 \pm 1-3/4} \mathrm{in.)}$ below the top of the reactor active fuel zone. The subassemblies were held down by a spring-loaded fixture attached to a clamp (Figure 6) which fitted into slots in the sides of the channel near the top. A standard-shape handle was attached to the clamp for lifting the assembly. The relative positions of the handle, clamp, and channel when the assembly was ready to be inserted in the reactor are indicated in Figure 7.

The spacer springs were made of Inconel " $X$." the leaf springs at the top of the assembly were made of Inconel " $X$ " 750, and the hold down springs were made of Inconel " $X$ ". Except for the fuel rods, the rest of the assembly, including the channel, was Type 304 stainless steel.

\section{FUEL ROD DESIGN}

The fuel rods that were subsequently incorporated in Assembly SA-1 were designed under the Fuel Cycle Program for VBWR operation in that program's Type $\mathrm{J}$ basic assemblies.' Table 1 lists some of the characteristics of these rods. They consisted of sintered $\mathrm{UO}_{2}$ pellets of about $95 \%$ of theoretical density. clad with $1.077 \mathrm{~cm}$ $(0.424$ in.) o.d. by $0.056 \mathrm{~cm}(0.022 \mathrm{in.}$ ) wall Zircaloy-2 tubing, and were $103.408 \mathrm{~cm}(40.712 \mathrm{in}$.) long.

An exploded view of a typical fuel rod is shown in Figure 8 . The Zircaloy-2 wafer and stainless steel plenum support tube held the pellets in place and maintained a plenum space for the fission gases. The end plugs were welded to the cladding to provide closure at each end of the tube."

\subsection{CLADDING THICKNESS}

The fuel rod cladding was designed to be "free-standing"; i.e., to withstand the external pressure of the coolant without requiring support by the $\mathrm{UO}_{2}$. Cladding stresses in the fuel rods were calculated using the following equations: ${ }^{3}$

$$
\begin{aligned}
& P_{c}=\frac{E}{4\left(1-\mu^{2}\right)}\left(\frac{t}{r}\right)^{3} \\
& \sigma_{e p}=\frac{-P r}{t}\left[1+\frac{6 W_{o} P_{c}}{t\left(P_{C}-P\right)}\right] \\
& \sigma_{t}=\frac{E \alpha \Delta T}{2(1-\mu)}
\end{aligned}
$$

* The shanks of the shorter end plugs (Figure A-7) were cut off before the rods were inserted into the SA-1 subassemblies. 


$$
\Delta T=\frac{(\mathrm{Q} / \mathrm{A}) \mathrm{t}}{\mathrm{K}}
$$

Where:

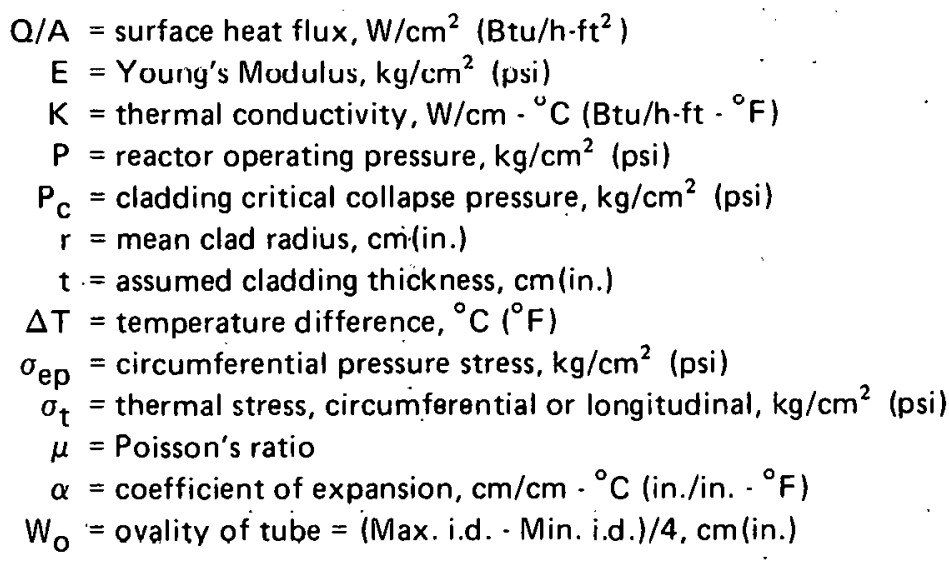

Table 1

CHARACTERISTICS OF TYPE J FUEL RODS SELECTED FOR ASSEMBLY SA-1

Cladding Material

Condition of Cladding Material, as received

Cladding Thickness, $\mathrm{cm}$. (in.)

Cladding i.d., $\mathrm{cm}$ (in.)

Cladding o.d., nominal, $\mathrm{cm}$ (in.)

Total Rod Length, nominal, $\mathrm{cm}$ (in.)

Pellet Diameter, cm (in.)

Pellet Density, \% of theoretical

Active Fuel Length, nominal, cm (in.)

Plenum Length, nominal, $\mathrm{cm}$ (in.)*

Wall thickness of Plenum Support Tube, nominal, cm (in.)

Initial Uranium Enrichment, specified, weight percent U-235
Zircaloy-2

Annealed

$0.056 \pm 0.0056(0.022 \pm 0.0022)$

$0.965 \pm 0.0041(0.380 \pm 0.0016)$

$1.077(0.424)$

$103.408(40.712)$

$0.955_{-0.008}^{+0.000}(0.376+0.0003)$

$95 \pm 1$

94 (37)

4.831 (1.902)

$0.076(0.030)$

$2.7,3.2$, and 3.5

The length of the plenum support tube in most rods is believed to have been $4.420 \mathrm{~cm}(1.740$ in.). However, post-irradiation examination revealed two such tubes (out of 19 from SA-1 rods that were actually measurad) that were $4.826 \mathrm{~cm}$ (1.900 in.) Iong. 


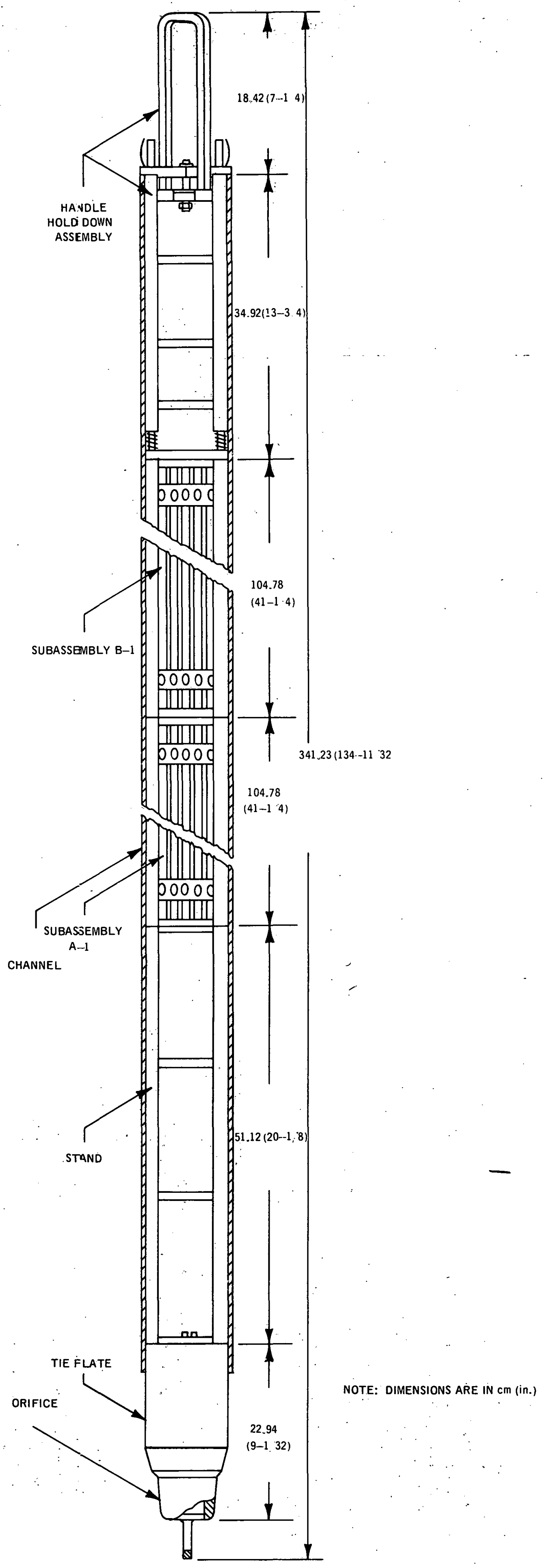

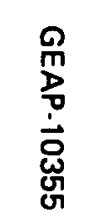




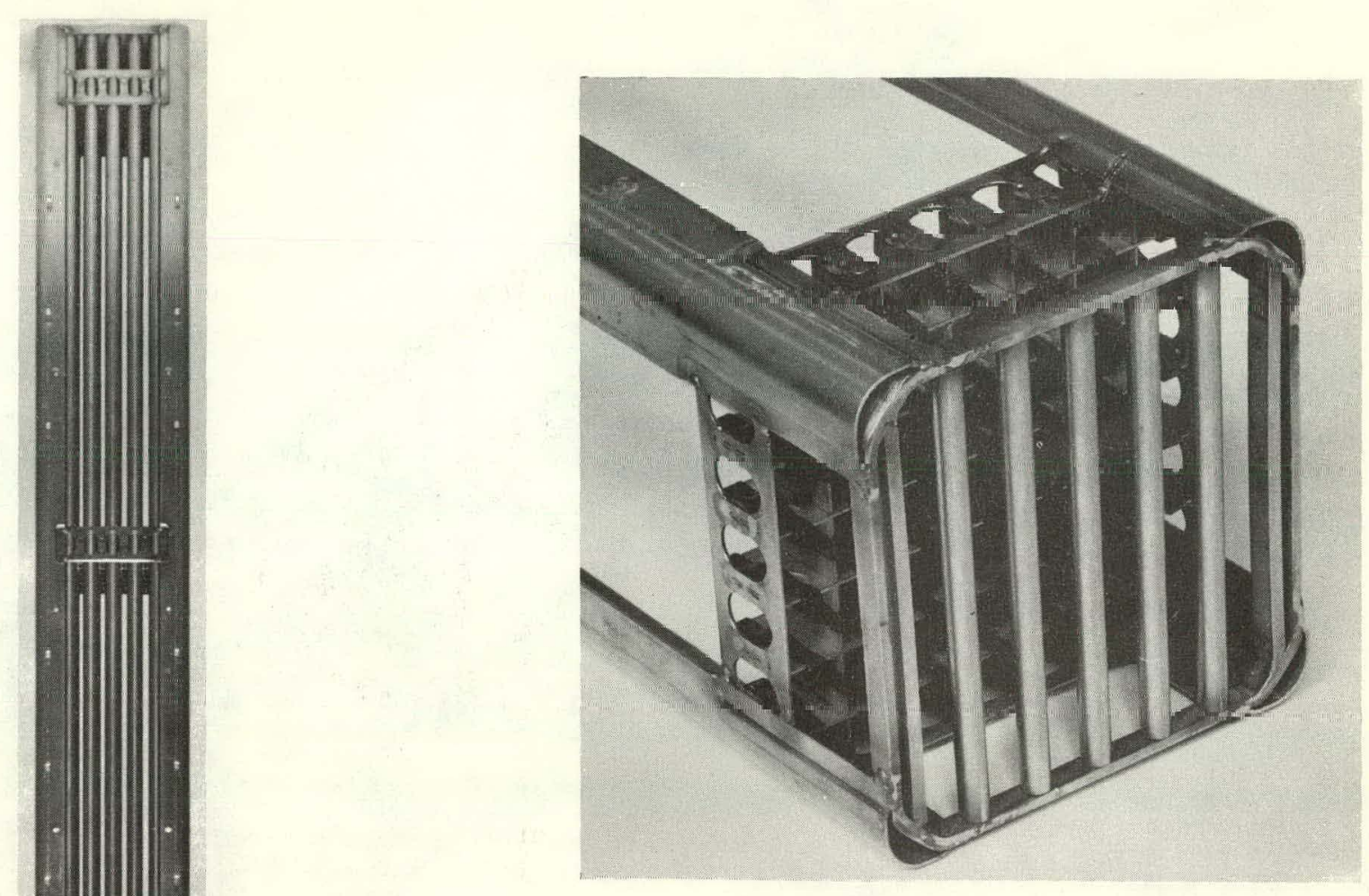

Figure 3. Bottom of Subassembly

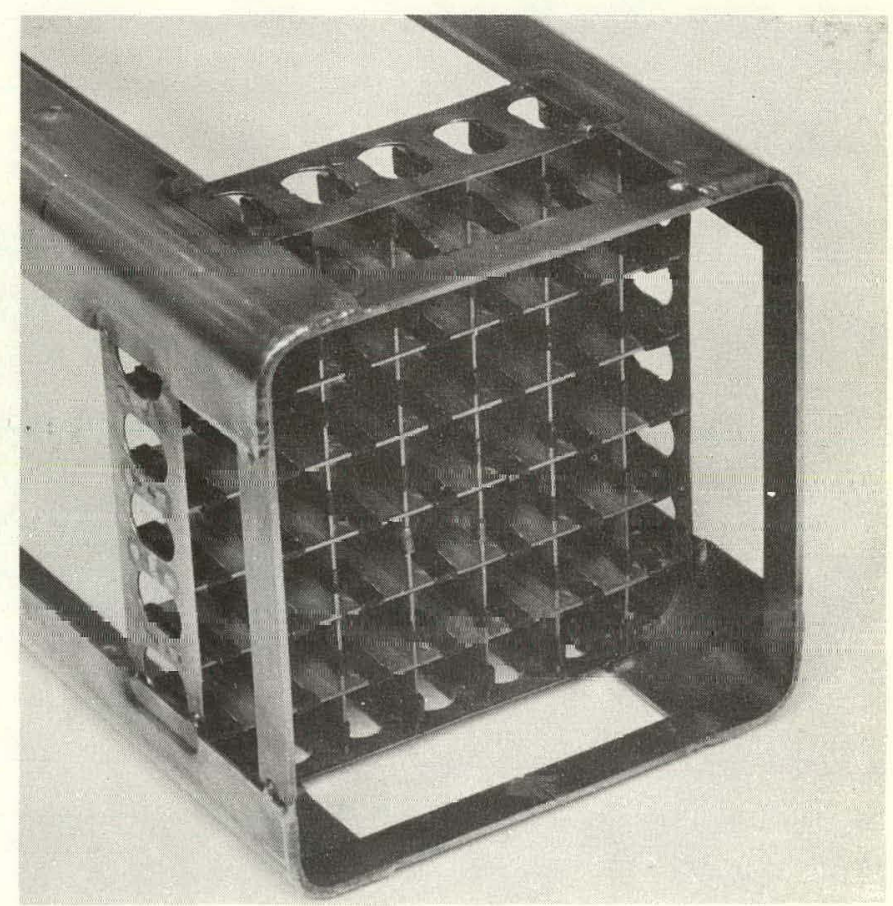




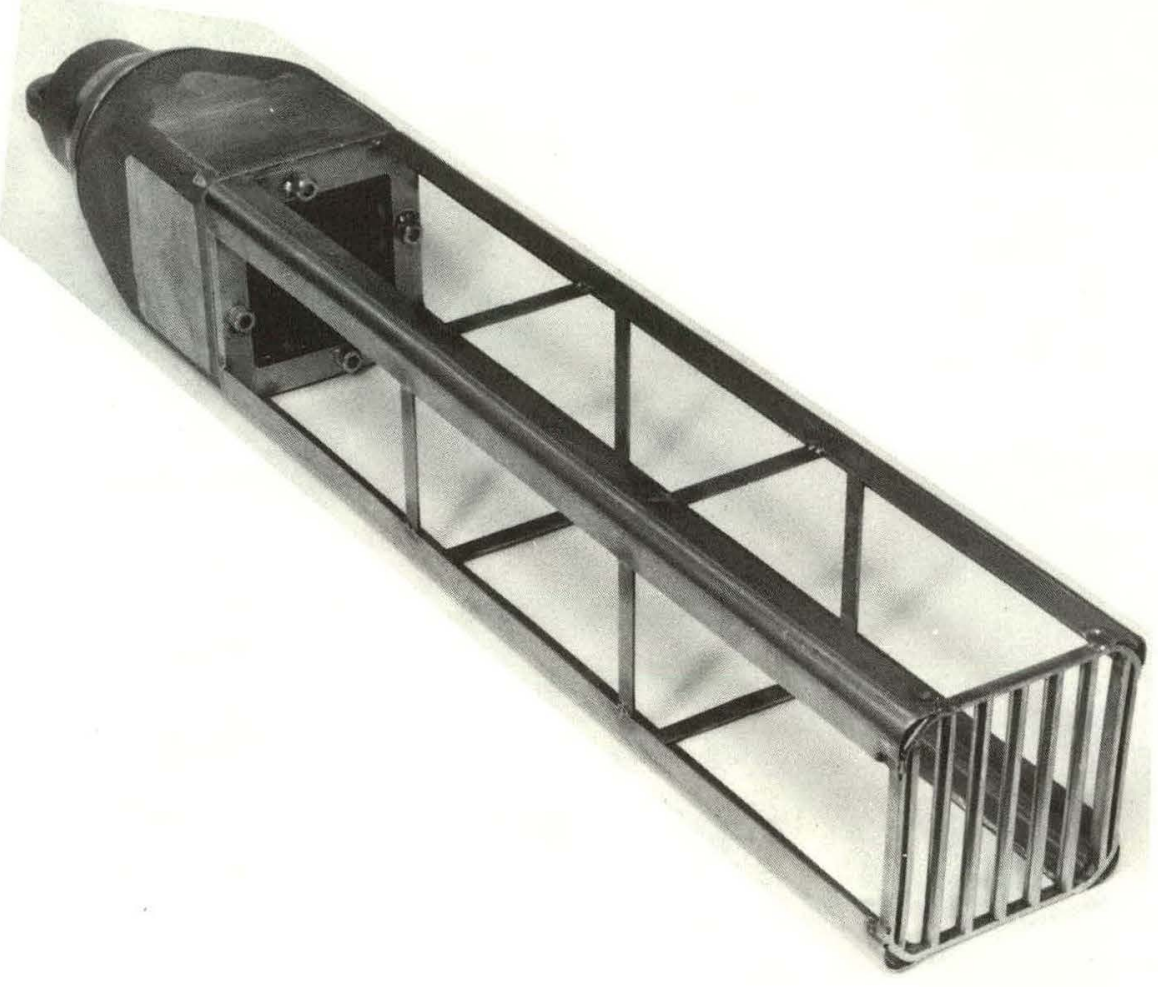

Figure 5. Assembly Nosepiece and Stand

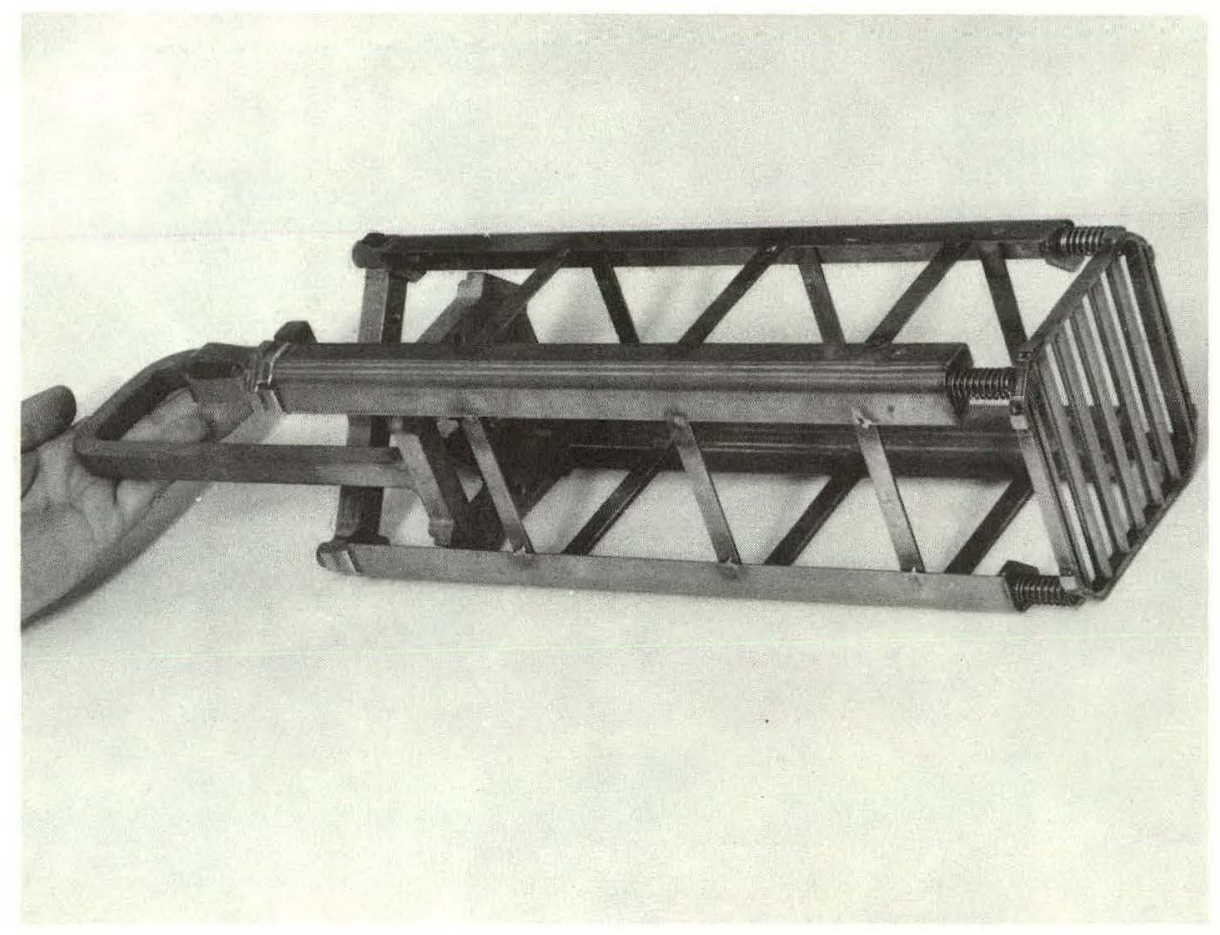

Figure 6. Handle Holddown Assembly 


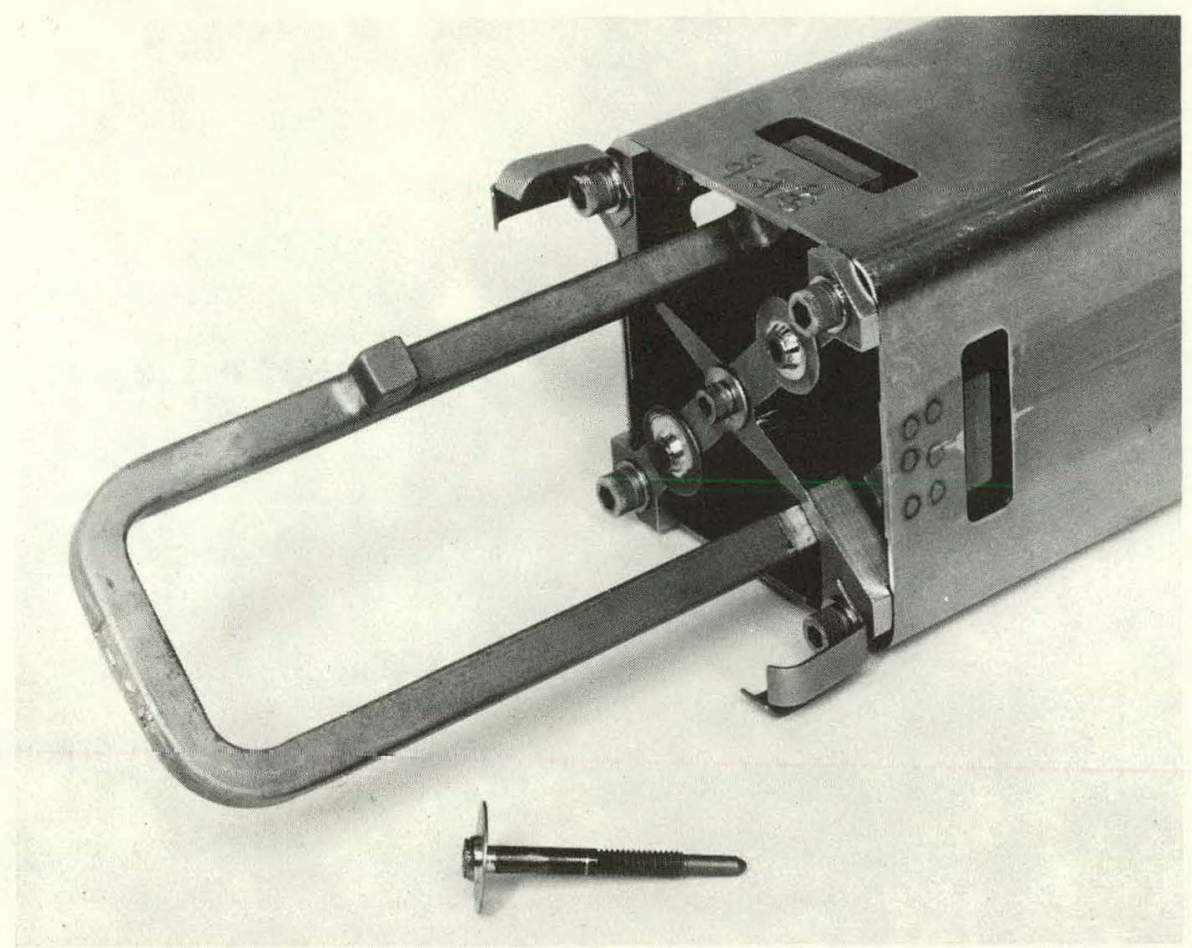

Figure 7. Top of Channeled Assembly

As the maximum circumferential stress is the sum of the thermal and pressure bending stresses, the total stress is:

$$
\sigma_{\text {total }}=\sigma_{\text {ep }}+\sigma_{\mathrm{t}}
$$

Rearranging the above equations, the maximum compressive circumferential stress, $\sigma_{\text {total }}$, can be obtained by substituting Equation 4 in Equation 3 and adding Equation 2 to give:

$$
\sigma_{\text {total }}=\frac{-\operatorname{Pr}}{t}\left[1+\frac{6 W_{o} P_{c}}{t\left(P_{c}-P\right)}\right]-\frac{\alpha E(Q / A) t}{2(1-\mu) K}
$$

After the reactor operating conditions have been established the cladding stresses can be determined using Equation 6 . In the design of the Type J cladding a safety factor was used which allowed for the possibility of a $25 \%$ overpressure and a $25 \%$ overpower during the operation of the VBWR. The reactor pressure would have been $87.9 \mathrm{~kg} / \mathrm{cm}^{2}(1250 \mathrm{psi})$ and the maximum heat flux would have been $183 \mathrm{~W} / \mathrm{cm}^{2}\left(582,000 \mathrm{Btu} / \mathrm{h}-\mathrm{ft}^{2}\right)$. The following values were used to determine cladding stresses:

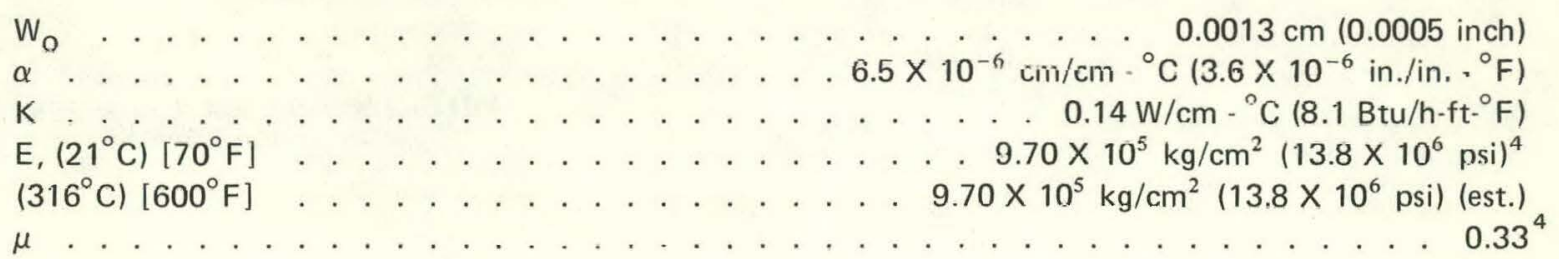




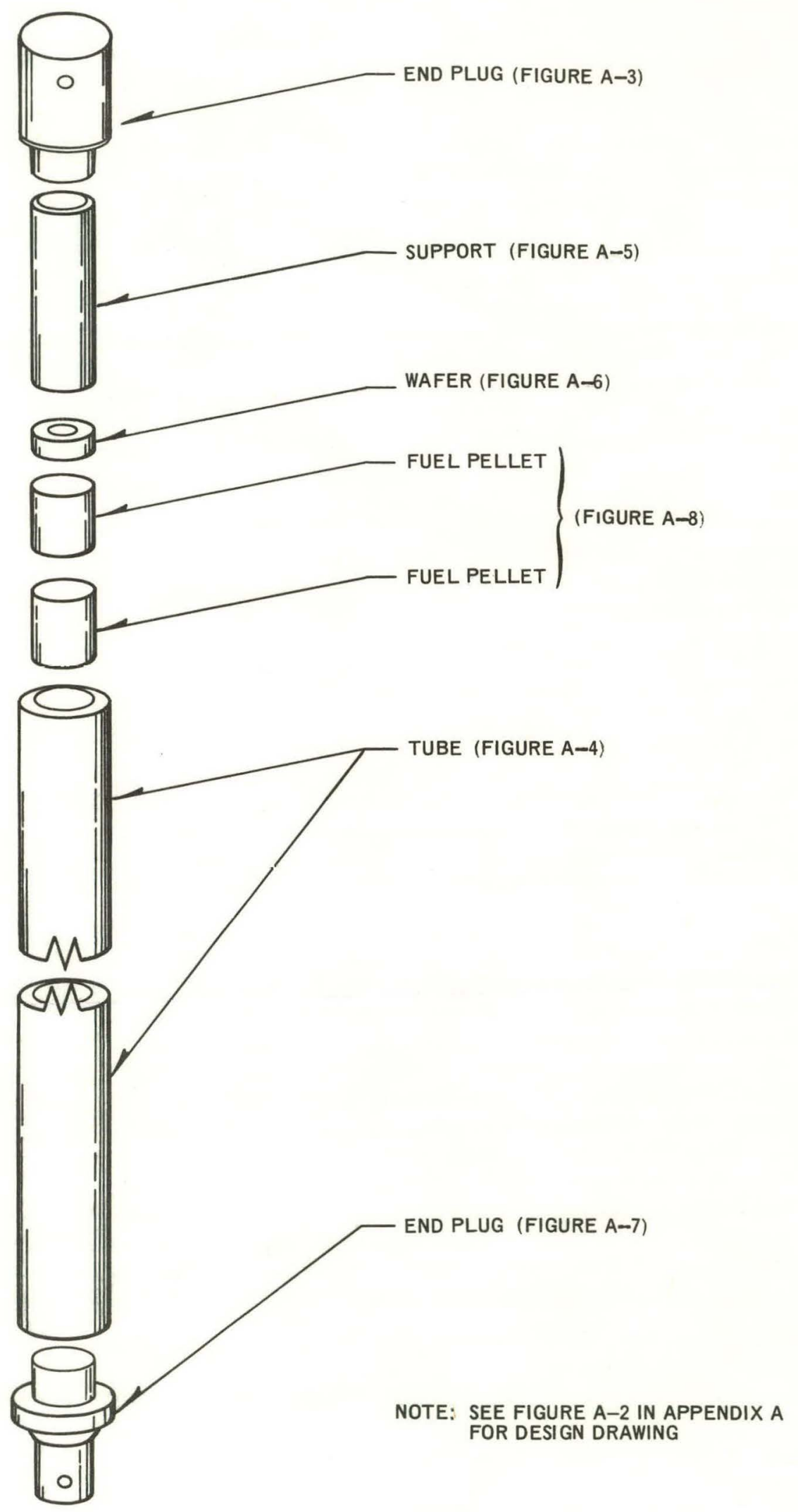

Figure 8. Exploded View of Fuel Rod 


\subsection{FISSION GAS RELEASE}

In the design of the fuel rods, an analysis was made to determine the magnitude of the fission gas pressure. The conditions described by Spalaris ${ }^{5}$ were used. In these analyses the following assumptions were made:

1. Forty-two percent of the fission gases are released. The remainder of the gases is retained in the $\mathrm{UO}_{2}$ pellets.

2. The volume available for the gas to collect is external to the $\mathrm{UO}_{2}$ fuel pellets and consists of the volume of the plenum in the cold condition.

3. The temperature of the gaseous fission products in the plenum is the weighted average of the temperatures of the surfaces with which it is in contact.

4. The neutron flux is uniform over the rod cross section, but is considered to have a sine distribution in the axial direction.

5. The gaseous fission products are perfect gases.

6. The $\mathrm{UO}_{2}$ contains permanent gas and water contents of $8.5 \times 10^{-3} \mathrm{~cm}^{3}$ per gram of $\mathrm{UO}_{2}$ and $3 \times 10^{-5} \mathrm{grams}$ per gram of $\mathrm{UO}_{2}$, respectively.

7. The fuel rod is backfilled with helium at $1.05 \mathrm{~kg} / \mathrm{cm}^{2}(15 \mathrm{psia})$.

The maximum fission gas pressure was calculated to be $166 \mathrm{~kg} / \mathrm{cm}^{2}(2360 \mathrm{psi})$. It was assumed that the fuel rod was operating at a peak heat flux of $183 \mathrm{~W} / \mathrm{cm}^{2}\left(582,000 \mathrm{Btu} / \mathrm{h}-\mathrm{ft}^{2}\right)$ and had reached an average burnup of $6 \times 10^{2} 0$ tissions $/ \mathrm{cm}^{3}$ (2U,UUU MWd/tu).

\subsection{ClADDING STRENGTH}

Using the methods for calculating the cladding stresses described in subsection 4.1 , the minimum allowable yield strength for the material was computed using the octahedral stress criterion described by Timoshenko. ${ }^{3}$ This criterion states that: failure of the cladding will occur when the vield stress is $\sigma_{y}=\left(T_{\text {oct }}\right) / 0.47$, where $T_{\text {oct }}$ represents the octahedral shear stress and is given by:

$$
T_{\text {oct }}=1 / 3\left[\left(\sigma_{\theta}-\sigma_{\mathrm{r}}\right)^{2}+\left(\sigma_{\mathrm{r}}-\sigma_{\mathrm{z}}\right)^{2}+\left(\sigma_{\mathrm{z}}-\sigma_{\theta}\right)^{2}\right]^{1 / 2}
$$

Where:

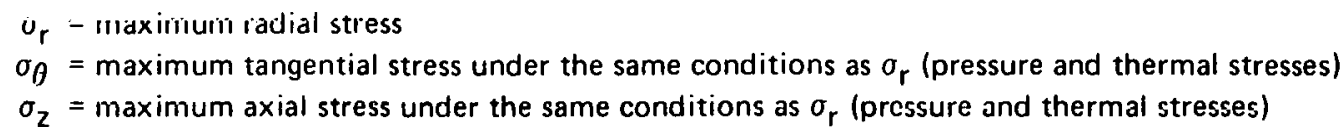

The maximum cladding stresses in the fuel rods are shown as a function of $\mathrm{UO}_{2}$ burnup in Figure 9 . The most serious condition, occurring after $6 \times 10^{20}$ fissions $/ \mathrm{cm}^{3}(20,000 \mathrm{MWd} / \mathrm{tU})$ burnup, is the one in which the outside surface of the cladding is exposed to the maximum tensile stresses. The octahedral shear stress ( $T_{\text {oct }}$ ) for the cladding after $6 \times 10^{20}$ fissinns $/ \mathrm{cm}^{3}$ was computer to he $373 \mathrm{~kg} / \mathrm{cm}^{2}$ (5300 psi), and by applying the failure criterion $\sigma_{y}=\left(\mathrm{T}_{\mathrm{oct}}\right) / 0.47$, the minimum allowable cladding yield strength at operating temperature $\left(343^{\circ} \mathrm{C}\right.$ or $\left.650^{\circ} \mathrm{F}\right) \mathrm{was}$ determined to be $795 \mathrm{~kg} / \mathrm{cm}^{2}(11,300 \mathrm{psi})$.

\section{FUEL FABRICATION}

\subsection{TUBING PROCESSING}

\subsubsection{Production Method}

A Zircaloy-2 ingot was prepared from zirconium sponge and alloying metals by double vacuum melting in consumable-electrode arc furnaces. Billets produced from the ingot were extruded into tube shells. Seamless tubing of the desired dimensions was fabricated from the shells by employing the drawing process and belt sanding the outside surface.

The material was received from the vendor in an annealed condition. The tubing had been cut into $102 \mathrm{~cm}$ (40 in.) lengths, and all surfaces of the tubes had been etched in a solution of hydrofluoric and nitric acids.

Five lots of tubing were fabricated. A lot was identified as that material produced from one $\sim 43 \mathrm{~kg}(95 \mathrm{lb}$.) extrusion billet. 
FUEL BURNUP (MNd/W)

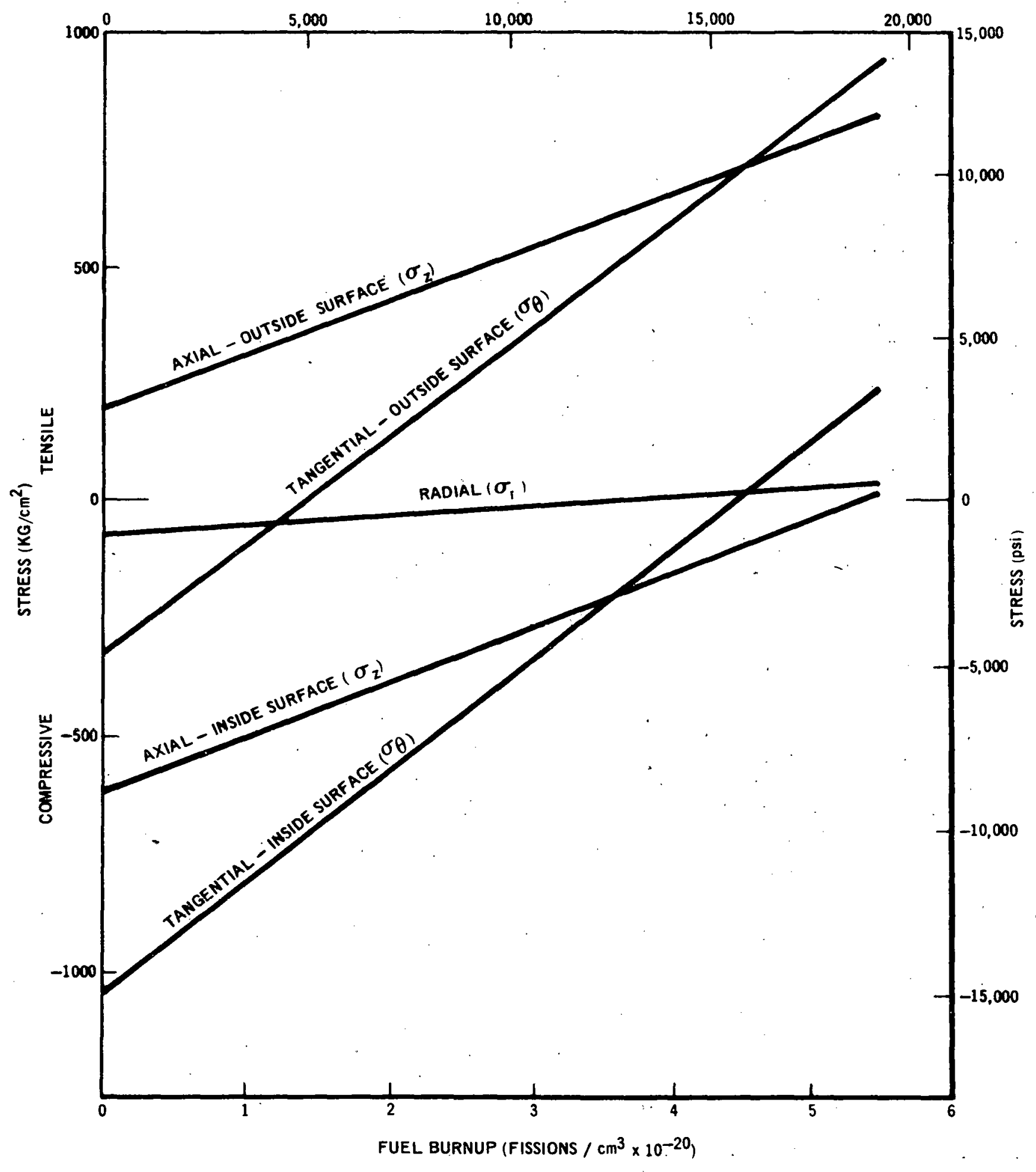

Figure 9. Maximum Cladding Stresses as a Function of Burnup ${ }^{1}$ 


\subsubsection{Mechanical, Chemical, and Metallurgical Specifications and Analyses}

The Zircaloy-2 tubing was manufactured and procured in conformance with General Electric specifications which were based on ASTM B353-60T.

The results of mechanical properties tests on samples from the five tubing lots, given in Table 2, indicate that the tubing met the mechanical properties specifications.

The vendor also subjected the tubing to the following tests:

a. Destructive hydrostatic pressure test (burst test) at room țemperature: one full length (102 $\mathrm{cm}$ or $40 \mathrm{in}$.) tube per lot. (See Table 2).

b. Nondestructive hydrostatic pressure test: all tubes held for 10 seconds at $200 \mathrm{~kg} / \mathrm{cm}^{2} \quad(2800 \mathrm{psi})$ at room temperature.

c. Flare test: one sample per lot. (Determines the capability of the tubing to be flared without visible cracking, with a tool having a 60 -degree included angle, until the specified outside diameter has been increased by $15 \%$.)

d. Eddy current test: all tubes tested to ensure that defects in excess of $10 \%$ of the specified nominal wall thickness are not present.

The vendor certifications for the five tubing lots indicated that the results of the above tests were acceptable.

The vendor tested two samples from each tubing lot for corrosion resistance by autoclaving them in steam for three days at $399^{\circ} \mathrm{C}\left(750^{\circ} \mathrm{F}\right)$ at a pressure of $105 \mathrm{~kg} / \mathrm{cm}^{2}(1500 \mathrm{psi})$. The weight gains were between 13 and $16 \mathrm{mg} / \mathrm{dm}^{2}$ (Table 3), i.e., less than the maximum allowable according to the specification $\left(22 \mathrm{mg} / \mathrm{dm}^{2}\right.$ ).

Chemical analyses on the several lots of tubing are given in Table 4. The chemical composition of the ingot met specifications according to the vendor's certification, although the G.E. analysis of tubing samples indicated the tin contents to be somewhat higher than the specified range. In addition, the manganese, hydrogen, nitrogen, and oxygen contents were to varying degrees above the specified levels according to the G.E. analyses. However, the tubing was accepted after reviewing the probable effects of the higher impurity contents on the performance of the fuel and considering the consequences of rejection with respect to the program schedule, which had already encountered several delays.

Metallographic examination of the tubing was performed at G.E. Photomicrographs of transverse sections of the tubing are shown in a. and b. of Figure 10. The grain size was determined to be ASTM No. 7. The general appearance of the transverse sections is quite normal and there is very little evidence of a hydride precipitate.

Photomicrographs of longitudinal sections of the tubing are shown in $\mathrm{c}$. and $\mathrm{d}$. of Figure 10. There were no significant differences in the grain size or hydride distribution between the transverse and longitudinal sections. However, the secondary phase (believed to be intermetallic compounds of zirconium and nickel, iron, and chromium) in the longitudinal sections is less evenly distributed and somewhat more stringered than in the transverse sections.

Although crystallographic orientation was not included in the tubing specifications, a specimen from each of two tubing lots, CA-4 and CA-1, was analyzed for this characteristic by $x$-ray diffraction. ${ }^{6}$ Nearly all of the basal planes $(0004)$ in both specimens were oriented parallel to the tube axis and also approximately parallel to the radial direction. The next highest population was approximately perpéndicular to the radial direction in both cases. However, the two specimens differed with respect to the orientations of the prismatic $(10 \overline{10})$ planes. The prismatic planes in the CA-4 specimen showed a ncarly rondom orientation albout the $c_{0}$ axis. At least the existente or anly hhing approaching a sharp texture was not indicated. In the CA-1 specimen the 1010 planes were highly oriented in directions that were related to the basal plane orientations and strongly suggest annealing textures. "wo strong concentrations of planes were found, both nearly parallel to the tangential direction. The stronger of the two was centered about a point approximately 75 degrees from the tube axis; the weaker was about 10 degrees from that axis.

\subsubsection{Visual and Dimensional Inspection}

A total of 605 tubes was received from the vendor for the fabrication of the Fuel Cycle Program's basic Zircaloy-2-clad fuel assemblies. All tubes were visually inspected and measured for length. The specifications called for an inside diameter of $0.965 \pm 0.0041 \mathrm{~cm} \quad(0.380 \pm 0.0016 \mathrm{in.})$ and a wall thirknass of $0.056 \pm 0.0056 \mathrm{~cm}$ $(0.022 \pm 0.0022 \mathrm{in.})$. The inside diameter and wall thickness were measured on a sampling of tubes from each of the five lots received. The results of these measurements are shown in Appendix $B$. The inside diameters ranged from $0.9645 \mathrm{~cm}$ to $0.9690 \mathrm{~cm}(0.37975 \mathrm{in}$. to $0.3815 \mathrm{in}$.$) , and the circumferential-average wall thicknesses ranged from$ $0.053 \mathrm{~cm}$ to $0.0585 \mathrm{~cm}(0.021 \mathrm{in}$. to $0.02305 \mathrm{in}$.). The difference in maximum and minimum wall thickness for a given tube ranged from $0.0013 \mathrm{~cm}$ to $0.0051 \mathrm{~cm}(0.0005 \mathrm{in.}$ to $0.002 \mathrm{in}$.). 
Table 2

MECHANICAL PROPERTIES TESTS ON TUBING SAMPLES

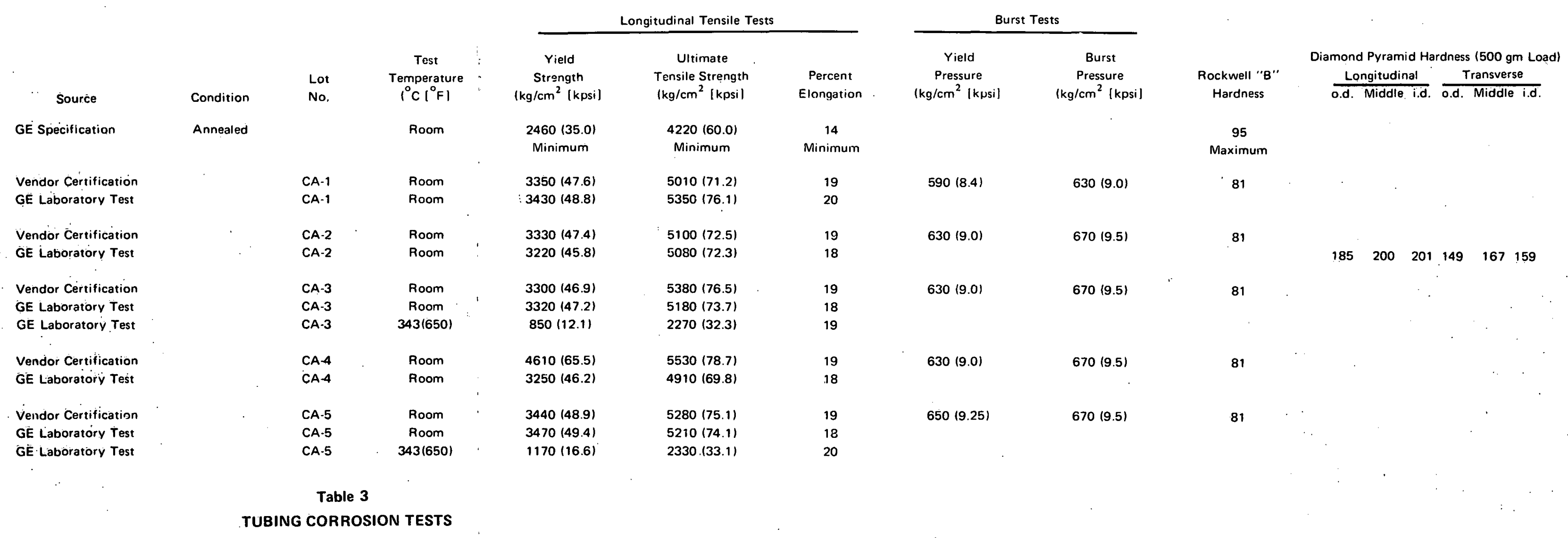

\section{DAYS in $399^{\circ} \mathrm{C}, 105 \mathrm{~kg} / \mathrm{cm}^{2}$ STEAM}

\begin{tabular}{|c|c|c|}
\hline $\begin{array}{l}\text { Sàmple } \\
\text { Identification }\end{array}$ & $\begin{array}{l}\text { Weight Gain } \\
\mathrm{mg} / \mathrm{dm}^{2}\end{array}$ & $\begin{array}{l}\text { Sample Appearance } \\
\text { at End of Test }\end{array}$ \\
\hline CA1-1 & 15 & Black lustrous film \\
\hline CA1-2 & 15 & Black lustrous film \\
\hline CA2.1 & 16 & Black lustrous film \\
\hline CA2-2 & 15 & Black lustrous film \\
\hline CA3-1 & 15 & Black lustrous film \\
\hline CA3-2 & 15 & Black lustrous film \\
\hline CA4:-1 & 14 & Black 'lustrous film \\
\hline CA4-2 & 13 & Black lustrous film \\
\hline CÁ5:1 & 14 & Black lustrous film \\
\hline CA5-2 & 14 & Black lustrous film \\
\hline
\end{tabular}




$$
\text { Table } 4
$$

CHEMICAL ANALYSIS OF TUBING

\begin{tabular}{|c|c|c|c|c|c|c|c|c|c|c|c|c|c|c|c|c|c|c|c|c|c|c|c|c|c|c|c|c|c|c|c|}
\hline & & & & ercent & & & & & & & & & & & & & & & & & & & & & & & & & & & \\
\hline Source & Lot & $\overline{s n}$ & $\mathrm{Fe}$ & $\mathrm{Cr}_{\mathrm{r}}$ & $\overline{\mathrm{Ni}}$ & $\overline{A l}$ & As & B & $\mathrm{C}$ & $\mathrm{Ca}$ & Cd & $\mathrm{Cl}$ & Co & $\mathrm{Cu}$ & $\mathrm{H}$ & $\mathrm{HF}$ & $\mathrm{Mg}$ & $\mathrm{Mn}$ & Mo & $\mathrm{N}$ & $\mathrm{Na}$ & 0 & $\mathrm{~Pb}$ & $\mathrm{sb}$ & $\mathrm{Si}$ & Ta & $\mathrm{Ti}$ & U & $\mathrm{v}$ & $\mathrm{w}$ & $\mathrm{Zn}$ \\
\hline GE Specification & & $\begin{array}{l}1.20 . \\
1.70\end{array}$ & $\begin{array}{l}0.07 . \\
0.20\end{array}$ & $\begin{array}{l}0.05- \\
0.15\end{array}$ & $\begin{array}{l}0.03 \text { - } \\
0.08\end{array}$ & $<75$ & & $<0.5$ & $<500$ & $<30$ & $<0.5$ & $<20$ & $<20$ & $<50$ & $<25$ & $<100$ & $<20$ & $<50$ & & $<80$ & $<20$ & $\begin{array}{l}900 \\
1500\end{array}$ & $<130$ & & $<120$ & & $<50$ & $<3.5$ & & $<100$ & \\
\hline Vendor Certification" & CA-1 & 1.52 & 0.13 & 0.09 & 0.06 & 30 & & $<0.2$ & $<100$ & $<20$ & $<0.5$ & $<15$ & $<20$ & 35 & 13 & 70 & $<20$ & $<20$ & $<20$ & 20 & $<10$ & 1030 & $<20$ & & 50 & & $<20$ & ¿ कं & $<20$ & $<20$ & \\
\hline Vendor Certification" & CA-2 & 1.52 & 0.13 & 0.09 & 0.06 & 25 & & $<0.2$ & $<100$ & $<20$ & $<0.5$ & $<15$ & $<20$ & 30 & 17 & 70 & $<20$ & $<20$ & $<20$ & 20 & $<10$ & 1270 & $<20$ & & 45 & & $<20$ & 1.4 & $<20$ & $<20$ & \\
\hline Vendor Certification* & CA-3 & 1.52 & 0.13 & 0.09 & 0.06 & 25 & & $<0.2$ & $<100$ & $<20$ & $<0.5$ & $<15$ & $<20$ & 30 & 17 & 65 & $<20$ & $<20$ & $<20$ & 25 & $<10$ & 1290 & $<20$ & & 35 & & $<20$ & 1.7 & $<20$ & $<20$ & \\
\hline Vendor Cerrification " & CA-4 & 1.52 & 0.13 & 0.09 & 0.06 & 25 & & $<0.2$ & $<100$ & $<20$ & $<0.5$ & $<15$ & $<20$ & 30 & 15 & 80 & $<20$ & $<20$ & $<20$ & 20 & $<10$ & 1190 & $<20$ & & 30 & & - $<20$. & 1.2 & $<20$ & $<20$ & \\
\hline Vendor Certification ${ }^{*}$ & CA-5 & 1.52 & 0.13 & 0.09 & 0.06 & $<20$ & & $<0.2$ & $<100$ & $<20$ & $<0.5$ & $<15$ & $<20$ & 20 & 13 & 75 & $<20$ & $<20$ & $<20$ & 25 & $<10$ & 1330 & $<20$ & & 35 & & $<20$ & 1.7 & $<20$ & $<20$ & \\
\hline GE Analysis & CA-1 & 1.80 & 0.13 & 0.105 & 0.043 & 64 & $<10$ & $<0.5$ & & & $<0.5$ & & $<10$ & 40 & 31 & $<10$ & 8 & 70 & & 126 & & 2160 & $<10$ & $<10$ & 110 & $<10$ & $<10$ & & & $<10$ & $<10$ \\
\hline GE Analysis & CA-2 & 1.80 & 0.125 & 0.11 & 0.042 & 64 & $<10$ & $\succ_{0.5}$ & & & $<0.5$ & & $<10$ & 32 & 27 & $<10$ & 8 & 70 & & 196 & & 2380 & $<10$ & $<10$ & 112 & $<10$ & $<10$ & & & $<10$ & $<10$ \\
\hline GE Analysis & $\mathrm{CA}-3$ & 2.00 & 0.125 & 0.105 & 0.048 & 64 & $<10$ & $<0.5$ & & & $<0.5$ & & $<10$ & 45 & 32 & $<10$ & 7 & 70 & & 124 & & 1880 & $<10$ & $<10$ & 110 & $<10$ & $<10$ & & & $<10$ & $<10$ \\
\hline GE Analysis & CA-1 & 1.90 & 0.16 & 0.125 & 0.056 & 68 & $<10$ & $<0.5$ & & & $<0.5$ & & $<10$ & 50 & 35 & $<10$ & 8.5 & 70 & & 127 & & $1 / 50$ & $<10$ & $<10$ & 115 & $<10$ & $<10$ & & & $<10$ & $<10$ \\
\hline GE Analysis & CA.5 & 1.80 & 0.12 & 0.107 & 0.043 & 62 & $<10$ & $<0.5$ & & & $<0.5$ & & $<10$ & 43 & 28 & $<10$ & 8 & 70 & & 104 & & 1460 & $<10$ & $<10$ & 109 & $<10$ & $<10$ & & & $<10$ & $<10$ \\
\hline
\end{tabular}

- Allov Analysis by vendor was performed on the ingot (designated as No. K-548). All other analyses were performed on the tubing. 


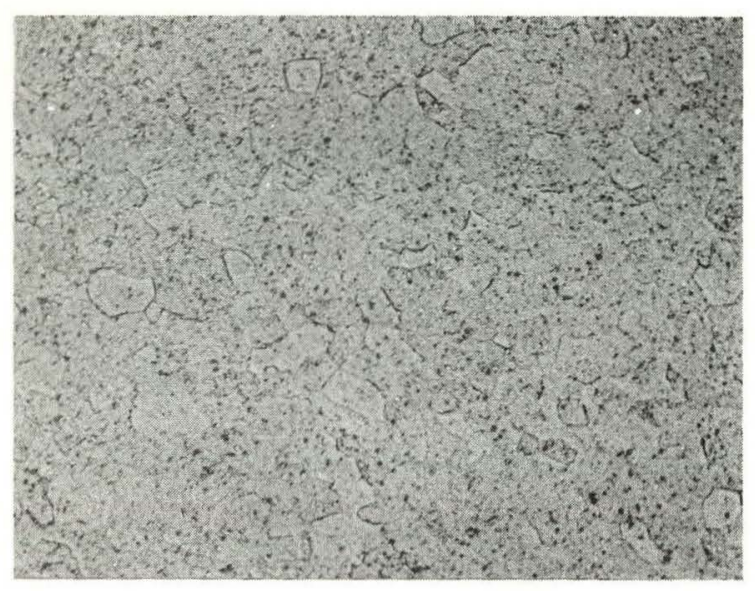

a

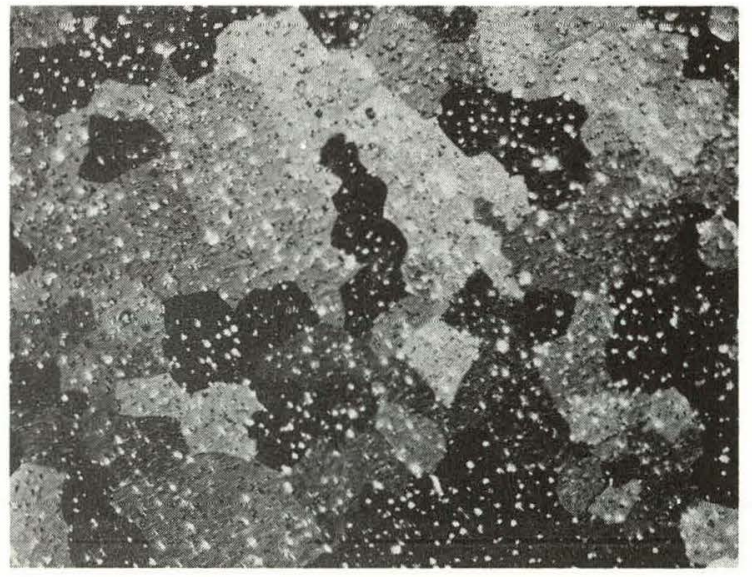

b

$\begin{array}{clcl}\text { PHOTO } & \text { ORIENTATION } & \text { MAG } & \text { ETCHANT } \\ \text { a. } & \text { TRANSVERSE } & 150 & \text { MICRO ETCH } \\ \text { b. } & \text { TRANSVERSE } & 210 & \text { MICRO ETCH } \\ \text { c. } & \text { LONGITUDINAL } & 250 & \text { MICRO ETCH } \\ \text { d. } & \text { LONGITUDINAL } & 250 & \text { MICRO ETCH }\end{array}$

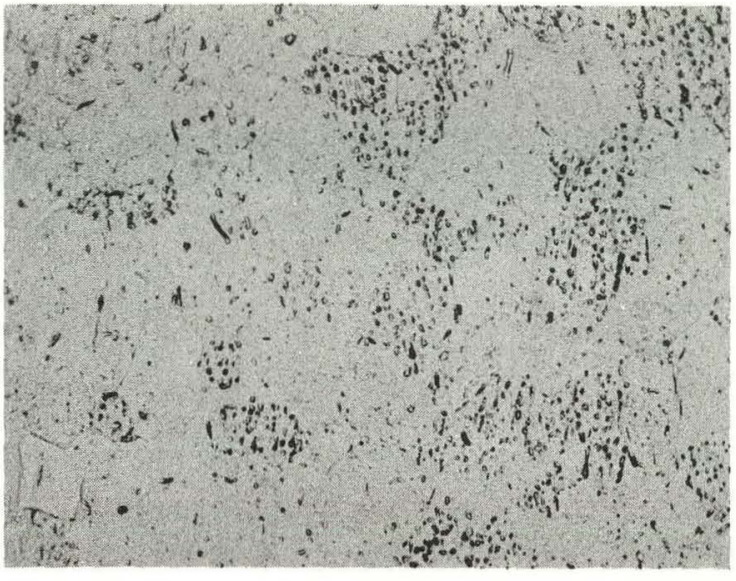

C

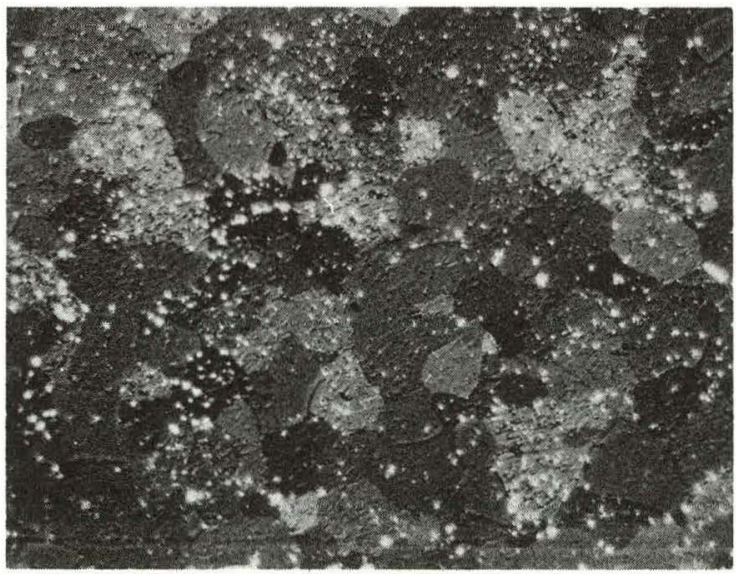

d

LIGHT

PURPOSE

B.F.

HYDRIDE DIS TRIBUTION

POLARIZED

B.F.

POLARIZED
GRAIN SIZE DETERMINATION HYDRIDE DISTRIBUTION GRAIN SIZE DETERMINATION

Figure 10. Hydride Distribution and Grain Size Determination in Transverse and Longitudinal Tubing Sections 
Any tubing which did not meet dimensional specifications was rejected with the following exception: Several tubes from Lot CA-4 in which the inside diameter at one end was up to $0.9716 \mathrm{~cm}(0.3825 \mathrm{in}$.) were accepted. This tubing was accepted because of the limited amount of tubing available. The identity of fuel rods fabricated from this out-of-specification tubing was maintained by assigning them a special series of fabrication numbers.

\subsubsection{Ultrasonic Inspection}

Dimensionally acceptable tubing was then ultrasonically tested for wall integrity. The acceptance criterion used was a defect size (depth) no larger than $9 \%$ of the wall thickness. However, tubing with higher levels of defect sizes also were accepted and used, with the objective of correlating ultrasonic inspection levels with fuel rod performance. Such tubing was characterized in the following manner: Tubing rejected at the $9 \%$ level was reinspected for defect levels corresponding to $18 \%, 31 \%, 45 \%$, and $>45 \%$ of wall thickness. Most of the reinspected tubing was found to fall in the $31 \%$ to $45 \%$ range. A typical tube from this group was sectioned and microscopically examined in the location of the prominent signal. It was discovered that the signal was caused by a scratch approximately $0.005 \mathrm{~cm}(0.002 \mathrm{in}$.$) deep, or$ slightly less than $10 \%$ of the wall thickness. The tubing actually was acceptable according to the original specification requirement. The cause of the discrepancy was the inability of the test equipment to differentiate between long shallow scratches and short deep ones. Based on this experience, only the tubes giving signals that indicated defects greater than $45 \%$ of the wall thickness were rejected. However, separation of the accepted tubes according to ultrasonic defect level, as well as to lot number, was maintained throughout the remaining fuel rod fabrication processes. About $95 \%$ of the as-received tubing passed the dimensional and ultrasonic inspections. (Note: All of the rods selected later for continued irradiation in Dresden as part of Assembly SA.1 were fabricated from tubes classed as acceptable at the ultrasonically determined $9 \%$ level.)

\subsubsection{Cleaning}

The tubing was cleaned first by pumice rubbing of the surface. It was then ultrasonically agitated for a minimum of 10 minutes in an alkaline bath at a temperature of $60^{\circ} \mathrm{C}\left(140^{\circ} \mathrm{F}\right)$. The bath was made up with Oakite 90 or Branson Formula B-72 cleaner in a concentration of $45 \mathrm{gm} / \mathrm{l}(6 \mathrm{oz} / \mathrm{gal})$ of water. The tubes were removed from the bath and were flushed in flowing tap water for at least 5 minutes. The cleanliness of the surfaces was checked by removing the tubes from the flowing water and examining the water film. If the film remained unbroken, the tubes were clean, and they were given a final rinse in deionized water at $71^{\circ} \mathrm{C}\left(160^{\circ} \mathrm{F}\right)$ for 5 minutes. If "water breaks" appeared after the tap water flush, the tubes were recycled through the uitrasonic bath.

The bath contained less than $30 \mathrm{ppm}$ of total chlorides and fluorides, and the final water rinse contained less than $1 \mathrm{ppm}$ of total chlorides and fluorides. The minimum resistivity of the final rinse water was 500,000 ohms. The tubes were not allowed to dry at any time between initial immersion in cleaning solution and autoclaving.

\subsubsection{Autoclaving}

The tubes were autoclaved for 36 hours at $105 \mathrm{~kg} / \mathrm{cm}^{2}(1500 \mathrm{psi})$ and $399^{\circ} \mathrm{C}\left(750^{\circ} \mathrm{F}\right)$. Deionized water of at least 500,000 ohms resistivity was used in the autoclaving process. Any tubing showing a white discoloration of the black oxide coating after autoclaving was rejected. (One of the autoclaves accidentally overheated to approximately $480^{\circ} \mathrm{C}$ $\left(900^{\circ} \mathrm{F}\right)$, which resulted in the loss of 44 pieces of tubing.) Segregation of the autoclaved tubes according to lot and ultrasoric defect level was maintained by placing them in polyethylene bags.

\subsubsection{Machining}

The tube ends were machined. to give a length of $100.233 \pm 0.013 \mathrm{~cm}(39.462 \pm 0.005 \mathrm{in}$.$) and a sharp 90-degree$ edge with the outside surface. The oxide coating on the outside surface was machined back $0.32 \mathrm{~cm}(1 / 8 \mathrm{in}$.) from each end. The surface was machined to the minimum depth which resulted in removal of the coating. The inside edges of the end faces were deburred with a minimum of chamfering. Tap water was used as the coolant during the machining operation. After machining, the tubes were ultrasonically cleaned, flushed, and rinsed according to the process described above. They were then dried in a hot air box for 30 minutes at a minimum temperature of $85^{\circ} \mathrm{C}\left(185^{\circ} \mathrm{F}\right)$.

\subsection{END PLUG PROCESSING}

The end plugs were machined from $1.59 \mathrm{~cm} 10.625 \mathrm{in}$.$) diameter, hot rolled, annealed, and centerless ground$ Zircaloy-2 rod. The rod stock was fabricated from Zircaloy-2 prepared by double vacuum melting in consumable electrode arc furnaces. 
The rod was manufactured and procured in conformance with General Electric specifications which were based on ASTM B351-60T. Data on the mechanical properties, chemical analysis, and corrosion properties of the end plug material, provided in the vendor certifications, are given in Table 5. The finished rod was ultrasonically inspected by the vendor; no indications of defects were detected.

The end plugs were machined from the rod stock to the dimensions prescribed by Drawing No. 145 A5393 and Drawing No. 145A5394. Each finished plug was visually inspected for defects, and the dimensions were checked to assure that they were within the tolerance limits. The end plugs were cleaned by the same method used to clean the tubing; i.e., ultrasonic alkaline bath cleaning followed by flushing with tap water, rinsing in deionized water, and drying in a hot air box.

\subsection{URANIUM DIOXIDE PROCESSING}

\subsubsection{Powder Production, Specifications, and Analyses}

The pellets used in the Fuel Cycle Program fuel rods were fabricated from ceramic grade $\mathrm{UO}_{2}$ powder produced by the ammonium diuranate method. In this method, $\mathrm{UF}_{6}$ gas is reacted with $\mathrm{NH}_{4} \mathrm{OH}$ to form a precipitate of ammonium diuranate (ADU). The $A D U$ is decomposed to $\mathrm{UO}_{2}$ by hydrolyzing in a mixture of steam and hydrogen at $800^{\circ} \mathrm{C}$. Residual fluorides which are not converted to $\mathrm{ADU}$ are removed during the hydrolyzing operation. The $\mathrm{UO}_{2}$ is hammer-milled to achieve final particle size.

The $\mathrm{UO}_{2}$ powder was obtained from two vendors. Three different enrichments were specified . 2 7. 3.2, and 3.5 weight percent $\cup 235$. The specification required that the enrichments of the powder received be within $+0.070 \%$ of these values and that the oxygen-to-uranium ratıo be within the range of 2.02 to 2.06 . The allowable limits on impurities are indicated in Table 6. The specification requiren the average particle size to be $1.00+0.15$ micron in diameter as measured by a Fisher Sub-Sieve Analyzer.

The standard GE inspection procedure was to obtain ten 50-gram samples of $\mathrm{UO}_{2}$ powder from each lot for the determination of the powder uniformity and compatability in the pelletization process. A composite 75-gram sample from each lot was tested for oxygen-to-uranium ratıo, enrichment, and impurity content. In addition, a certified analysis was received from the vendor. Chemical analyses of samples from all powder lots used to fabricate the fuel rods that were later incorporated in Assembly SA-1 are given in Table 6.

\subsubsection{Powder Preparation}

A flow diagram that outlines both the preparation of the $\mathrm{UO}_{2}$ powder and the pellet fabrication is shown in Figure 11. Solid paraffin wax binder material was ground cold and maintained at a temperature of $26^{\circ} \mathrm{C}\left(-15^{\circ} \mathrm{F}\right)$ until it was added to the uranium dioxide powder. The binder particle size was 20 mesh Tyler standard screen size. An amount of binder equivalent to $2.5 \%$ was blended into the powder with a hand paddle. The binder and powder were then mixed by milling in a planetary ball mill that contained steel balls. The milled powder was granulated and sized by dry screening on a 20 -mesh screen. Sterotex lubricant in a quantity equivalent to $0.2 \%$ of the $\mathrm{UO}_{2}$ weight finally was blended with the powder in a rotating drum blender. The minimum apparent density of the finished powder was specified as $2.5 \mathrm{gm} / \mathrm{cm}^{3}$.

\subsubsection{Pellet Fabrication}

The finished powder was cold pressed into cylindrical compacts. To establish the optımum compacting pressure, a preliminary run (sinterability test) was made on samples from each powder lot. It was found that compacting to green densities between 5.9 and $6.3 \mathrm{gm} / \mathrm{cm}^{3}$ resulted in sintered pellets of acceptable densities.

Before being sintered, the green pellets were heated to $450^{\circ} \mathrm{C}$ in a hydrogen atmosphere to remove the binder and lubricant through volatilization.

The green, dewaxed pellets were next'sintered in a hydrogen atmosphere at $1550^{\circ} \mathrm{C}$. The pellets were held at the sintering temperature approximately 5 hours. When the sintered pellets had cooled to room temperature, they were wet centerless ground to the desired diameter. The pellets were subsequently air-dried in an oven at a temperature of $120^{\circ} \mathrm{C}$ for a minimum of 2 hours.

One end of each pellet was indented during pressing with a mark that identified its enrichment. The mark covered $25 \%$ to $30 \%$ of the end surface area and was 0.005 to $0.025 \mathrm{~cm}(0.002$ to $0.010 \mathrm{in}$.) deep.

The densities of sample pellets, determined immediately after the sintering step using the water immersion method, are given in Table 7. The average densities of samples from the several sintering boats ranged from $93.5 \%$ to $96.0 \%$ of theoretical $\mathrm{UO}_{2}$. 
Table 5

MECHANICAL PROPERTIES, CHEMICAL ANALYSIS, AND

CORROSION PROPERTIES OF END PLUG MATERIAL

A. Room Temperature Tensile Test Results, Hardness Measurements, and Grain Size Measurements

\begin{tabular}{|c|c|c|c|c|c|c|c|c|c|}
\hline \multirow[b]{3}{*}{ Heat Number } & \multirow{3}{*}{$\begin{array}{l}\text { Yield Strength } \\
(0.2 \% \text { Offset }) \\
\left(\mathrm{kg} / \mathrm{cm}^{2}[\mathrm{kpsi}]\right)\end{array}$} & \multirow{3}{*}{$\begin{array}{c}\text { Ultimate } \\
\text { Tensile Strength } \\
\left(\mathrm{kg} / \mathrm{cm}^{2}[\mathrm{kpsi}]\right)\end{array}$} & \multirow{3}{*}{$\begin{array}{l}\text { Elongation } \\
\text { (Percent in } \\
(5.1 \mathrm{~cm}[2 \text { in. }])\end{array}$} & \multicolumn{4}{|c|}{$\begin{array}{r}\text { Hardness } \\
\end{array}$} & \multirow{2}{*}{\multicolumn{2}{|c|}{$\begin{array}{c}\text { Grain Size } \\
\text { (ASTM Number) }\end{array}$}} \\
\hline & & & & & well "B" & & & & \\
\hline & & & & Average & Range & $\overline{\text { Average }}$ & Range & Longitudinal & Transverse \\
\hline 16-1226-Zr2 & $3830(54.5)$ & $5410(77.0)$ & 19 & 85.8 & 85.5-86 & 171 & $168-172$ & 8 & 8 \\
\hline 1216-717-Zr2 & $3320(47.2)$ & $5220(74.3)$ & 17 & 88 & 88-88 & 170 & $.167-172$ & 8 & 8 \\
\hline
\end{tabular}

B. Ingot Composition and Impurity Content

\begin{tabular}{|c|c|c|c|c|c|c|c|c|c|c|c|c|c|c|c|c|c|c|c|c|c|c|c|c|c|c|c|c|c|c|}
\hline \multirow[b]{2}{*}{ Heat Number } & \multirow[b]{2}{*}{ Location } & \multicolumn{5}{|c|}{$\begin{array}{c}\text { Composition } \\
\text { (Weight Percent) }\end{array}$} & \multicolumn{16}{|c|}{$\begin{array}{c}\text { Ingot Impurity Content } \\
\text { (ppm) }\end{array}$} & & & & & & \multicolumn{3}{|c|}{$\begin{array}{c}\text { Rod Analysis } \\
\text { (ppm) }\end{array}$} \\
\hline & & $\overline{S n}$ & $\mathrm{Fe}$ & $\mathrm{Cr}$ & $\mathrm{Ni}$ & $2 r$ & Al & B & Cd & C & $\mathrm{Ca}$ & $\mathrm{Cl}$ & Co & $\mathrm{Cu}$ & $\overline{H f}$ & $\mathrm{H}$ & $\mathbf{P b}$ & $\mathrm{Mg}$ & $M n$ & Mo & $\mathbf{N}$ & 0 & $\mathbf{S i}$ & $\mathrm{Ti}$ & W & U & $\mathrm{v}$ & $\overline{\mathrm{H}}$ & $N$ & $\overline{0}$ \\
\hline $1216-1226-Z r 2$ & Top & 1.51 & 0.14 & 0.09 & 0.06 & Bal. & 66 & $<0.2$ & $<0.3$ & 90 & $<30$ & $<15$ & $<5$ & $<25$ & 67 & 12 & 10 & $<10$ & $<10$ & $<10$ & 34 & 1125 & $<10$ & 20 & $<25$ & 0.5 & $<5$ & 7 & 40 & 1300 \\
\hline & Bottom & 1.51 & 0.14 & 0.09 & 0.06 & Bal. & 69 & $<0.2$ & $<0.3$ & 120 & $<30$ & $<15$ & $<5$ & $<25$ & 80 & 16 & 10 & $<10$ & $<10$ & $<10$ & 32 & 1480 & $<40$ & 20 & $<25$ & 0.6 & $<5$ & & & \\
\hline $1216-717-\mathrm{Zr} 2$ & Top & 1.51 & 0.17 & 0.09 & 0.06 & Bal. & 66 & $<0.2$ & $<0.3$ & 110 & $<30$. & $<15$ & $<5$ & $<20$ & 61 & 20 & 10 & $<10$ & 10 & $<10$ & 23 & 1330 & 50 & $<20$ & $<40$ & 1.8 & $<5$ & 7 & 42 & - - \\
\hline & Bottom & 1.50 & 0.13 & 0.08 & 0.04 & Bal. & 64 & $<0.2$ & $<0.3$ & 120 & $<30$ & $<15$ & $<5$ & $<20$ & 50 & 17 & 10 & $<10$ & 10 & $<10$ & 30 & 1250 & 50 & $<20$ & $<40$ & 2.2 & $<5$ & & & \\
\hline
\end{tabular}

c. Corrosion Test nesults

3 Days at $399^{\circ} \mathrm{C}\left(750^{\circ} \mathrm{F}\right)$ and $105 \mathrm{~kg} / \mathrm{cm}^{2}$ (1500 psi)

\begin{tabular}{|c|c|c|c|}
\hline Heat Number & $\begin{array}{l}\text { Sample } \\
\text { Number }\end{array}$ & $\begin{array}{c}\text { Weight Gain } \\
\left(\mathrm{mg} / \mathrm{dm}^{2}\right)\end{array}$ & Visual Appearance \\
\hline $1216-1226 \cdot \mathrm{Zr} 2$ & $\begin{array}{l}1226-Z \mathrm{Z} 2-11 \\
1226-\mathrm{Zr} 2 \cdot 12\end{array}$ & $\begin{array}{l}22.13 \\
20.97\end{array}$ & $\begin{array}{l}\text { Shiny black temper film } \\
\text { Shiny black temper film }\end{array}$ \\
\hline 1216-717-Zr2 & $\begin{array}{l}717-Z \mathrm{Z} \cdot 2 \cdot 3 \\
717-702 \cdot 4\end{array}$ & 21.85 & Shiny black teinjer fillm \\
\hline
\end{tabular}




$$
\text { Table } 6
$$

ANALYSIS OF UO 2 POWDER AND PELLETS

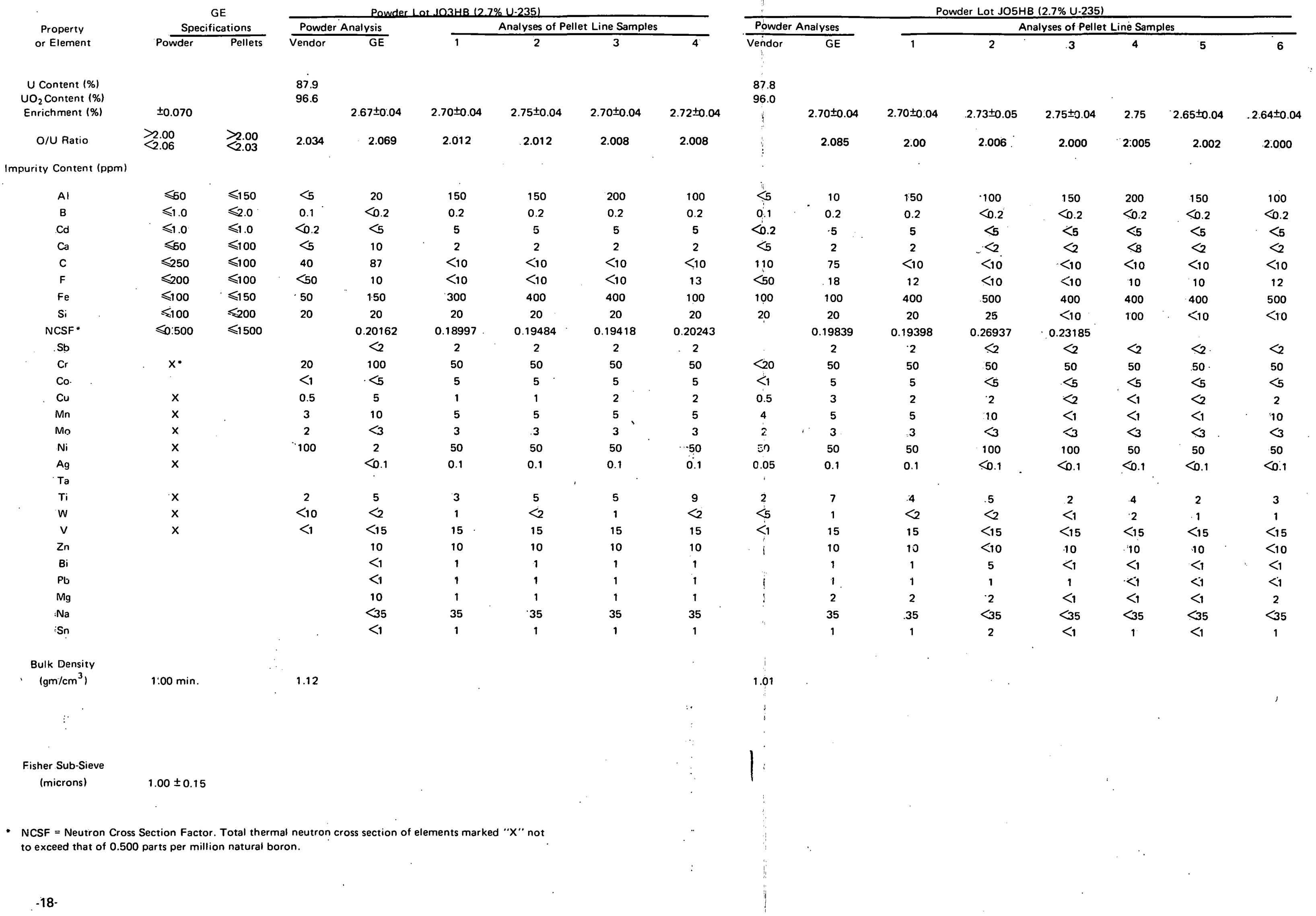




\begin{tabular}{|c|c|c|c|c|c|c|c|c|c|c|c|c|c|c|}
\hline \multirow{3}{*}{$\begin{array}{l}\text { Property } \\
\text { or Element }\end{array}$} & \multirow{2}{*}{\multicolumn{2}{|c|}{$\begin{array}{c}\text { GE } \\
\text { Specifications } \\
\end{array}$}} & \multicolumn{4}{|c|}{ Powder Lot JO4HC (3.2\% U-235) } & \multicolumn{3}{|c|}{$\begin{array}{c}\text { Powder Lot JO10D } \\
\text { (3.5\% U.235) }\end{array}$} & \multicolumn{3}{|c|}{$\begin{array}{c}\text { Powder Lot J02DD } \\
\text { (3.5\% U.235) }\end{array}$} & \multicolumn{2}{|c|}{$\begin{array}{c}\text { Powder Lot } \\
122360-6 \text { (3.5\% U-235 }\end{array}$} \\
\hline & & & \multicolumn{2}{|c|}{ Powder Analyses } & \multicolumn{2}{|c|}{ Pellet Analyses } & \multirow{2}{*}{\multicolumn{2}{|c|}{$\begin{array}{l}\text { Powder Analyses } \\
\text { Vendor GE }\end{array}$}} & \multirow{2}{*}{$\begin{array}{c}\text { Pellet } \\
\text { Analyses (a) }\end{array}$} & \multirow{2}{*}{\multicolumn{2}{|c|}{$\begin{array}{l}\frac{P \text { Powder Analyses }}{\text { Pendor GE }} \\
\text { Vento }\end{array}$}} & \multirow{2}{*}{$\begin{array}{c}\text { Pellet } \\
\text { Analyses }(b)\end{array}$} & \multirow{2}{*}{\multicolumn{2}{|c|}{$\begin{array}{l}\text { Powder Analyses } \\
\text { Vendor GE }\end{array}$}} \\
\hline & Powder & & & & & 2 & & & & & & & & \\
\hline$U$ Content (\%) & & & 87.8 & & & & 87.4 & & & 87.9 & & & 87.79 & \\
\hline $\mathrm{UO}_{2}$ Content $(\%)$ & & & 96.6 & & & & & & & & & & & \\
\hline Enrichment $(\%)$ & \pm 0.070 & & & $3.22 \pm 0.05$ & $3.24 \pm 0.05$ & $3.20 \pm 0.0$ & & $3.45 \pm 0.05$ & $3.50 \pm 0.05$ & & $3.50 \pm 0.05$ & $3.49 \pm 0.05$ & & $3.47 \pm 0.05$ \\
\hline O/U Ratio & $<2.02$ & $\begin{array}{l}>2.00 \\
<2.03\end{array}$ & 2.03 & 2.062 & 2.004 & 2.000 & & 2.114 & 2.004 & & 2.111 & 2.006 & 2.05 & 2.083 \\
\hline npurity Content (ppm) & & & & & & & & & & & & & & \\
\hline Al & $\leqslant 50$ & $\leqslant 150$ & $<5$ & 20 & 50 & 100 & & 20 & 150 & & 20 & 200 & 10 & 100 \\
\hline B & $\leqslant 10$ & $\leqslant 2.0$ & 0.1 & $<0.2$ & $<0.2$ & $<0.2$ & 0.1 & 0.4 & 0.2 & 0.1 & 0.2 & 0.2 & 0.5 & $<.2$ \\
\hline Cod & «. & ×. & 50.2 & 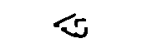 & 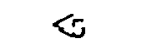 & 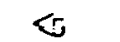 & & $<1$ & $<1$ & & $\leqslant$ & i & 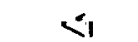 & $\vdots$ \\
\hline ca & $\leqslant 50$ & $\leqslant 100$ & 5 & $<2$ & $<_{2}$ & $<2$ & 5 & $<2$ & $<2$ & 10 & $<2$ & 2 & 0.5 & $<_{2}$ \\
\hline c & $\leqslant 250$ & $\leqslant 100$ & 60 & $<10$ & $<10$ & $<10$ & & $<10$ & $<10$ & & $<10$ & $<10$ & 90 & 90 \\
\hline$F$ & $\leqslant 200$ & $\leqslant 100$ & 30 & $<10$ & 11 & $<10$ & 57 & 76 & 11 & 32 & 33 & $<10$ & $<50$ & $<10$ \\
\hline $\mathrm{Fe}$ & $\leqslant 100$ & $\leqslant 150$ & 270 & 300 & 400 & 500 & 90 & 150 & 150 & 150 & 150 & 200 & 62 & 100 \\
\hline $\mathrm{si}$ & $\leqslant 100$ & $\leqslant 200$ & 20 & 25 & 20 & $<10$ & 80 & 60 & 60 & 83 & 100 & 50 & 90 & 100 \\
\hline NCSF & $\leqslant 0.500$ & $\leqslant 0.500$ & & 0.26599 & 0.34654 & & & & & & & & $<0.35$ & \\
\hline $\mathrm{Sb}$ & & & & $<2$ & $<2$ & $<_{2}$ & & $<2$ & $<2$ & & $<2$ & 1 & & $<2$ \\
\hline $\mathrm{cr}_{\mathrm{r}}$ & $x$ & & 60 & 50 & 50 & 50 & 50 & 50 & 20 & 200 & 100 & 100 & $<5$ & 10 \\
\hline Co & & & $<1$ & $<5$ & $<5$ & $<5$ & & $<2$ & $<2$ & & $<2$ & 2 & $<3$ & $<2$ \\
\hline cu & $x$ & & 0.5 & 2 & $<2$ & $<2$ & 5 & 3 & 1 & 8 & 10 & 6 & 2 & 2 \\
\hline $\mathrm{Mn}$ & $x$ & & 4 & 10 & $<1$ & $<1$ & & $<1$ & $<1$ & & $<1$ & 1 & $<3$ & $<1$ \\
\hline Mo & $\hat{x}$ & & 2 & $<3$ & $<3$ & $<3$ & 3 & $<3$ & $<3$ & 49 & $<3$ & 3 & $<1$ & $<2$ \\
\hline Mi & $x$ & & 200 & 100 & 200 & 200 & 200 & 100 & 100 & 185 & 200 & 200 & 6 & 5 \\
\hline $\mathrm{Ag}_{9}$ & $x$ & & $<0.01$ & $<0.1$ & $<0.1$ & $<0.1$ & $<0.01$ & 5 & 1 & $<0.01$ & 5 & 0.1 & $<0.1$ & 3 \\
\hline Tá & & & & & & & & $\sigma_{2}$ & 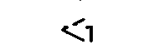 & & $<1$ & 1 & & $<2$ \\
\hline $\mathrm{Ti}$ & $x$ & & 1 & 3 & 3 & 7 & & 30 & 60 & & 60 & 1 & $<10$ & 30 \\
\hline$w$ & $x$ & & $<5$ & $<2$ & $<1$ & $<1$ & & 15 & 15 & & 15 & 8 & $<10$ & 5 \\
\hline v & $x$ & & $<1$ & $<15$ & $<15$ & $<15$ & & $<15$ & $<15$ & & $<15$ & 15 & $<10$ & $<15$ \\
\hline$z n$ & & & & $<10$ & 10 & 10 & & 20 & 20 & & 20 & 20 & & 20 \\
\hline Bi & & & & 5 & $<1$ & $<1$ & & $<1$ & $<1$ & & ৫ & 1 & & ¿1 \\
\hline $\mathrm{Pb}$ & & & & 1 & $<1$ & 1 & 1 & 5 & $<1$ & 9 & 10 & 1 & & 1 \\
\hline $\mathrm{Mg}$ & & & & 2 & $<1$ & $<1$ & & 1 & 1 & & 1 & 1 & & $<1$ \\
\hline $\mathrm{Na}$ & & & & $<35$ & $<35$ & $<35$ & & $<35$ & $<35$ & & $<35$ & 35 & & $<35$ \\
\hline Sn & & & & 2 & 1 & 1 & 4 & 2 & 2 & & 2 & 1 & & 2 \\
\hline $\mathrm{Cl}$ & & & & & & & & & & & & & $<20$ & \\
\hline
\end{tabular}

Bulk Density

$1.00 \mathrm{~min}$.

1.28

Fisher Sub-Sieve

$1.00 \pm 0.15$

(a) Boat Card No. 2645

(b) Boat Card No. 2649 


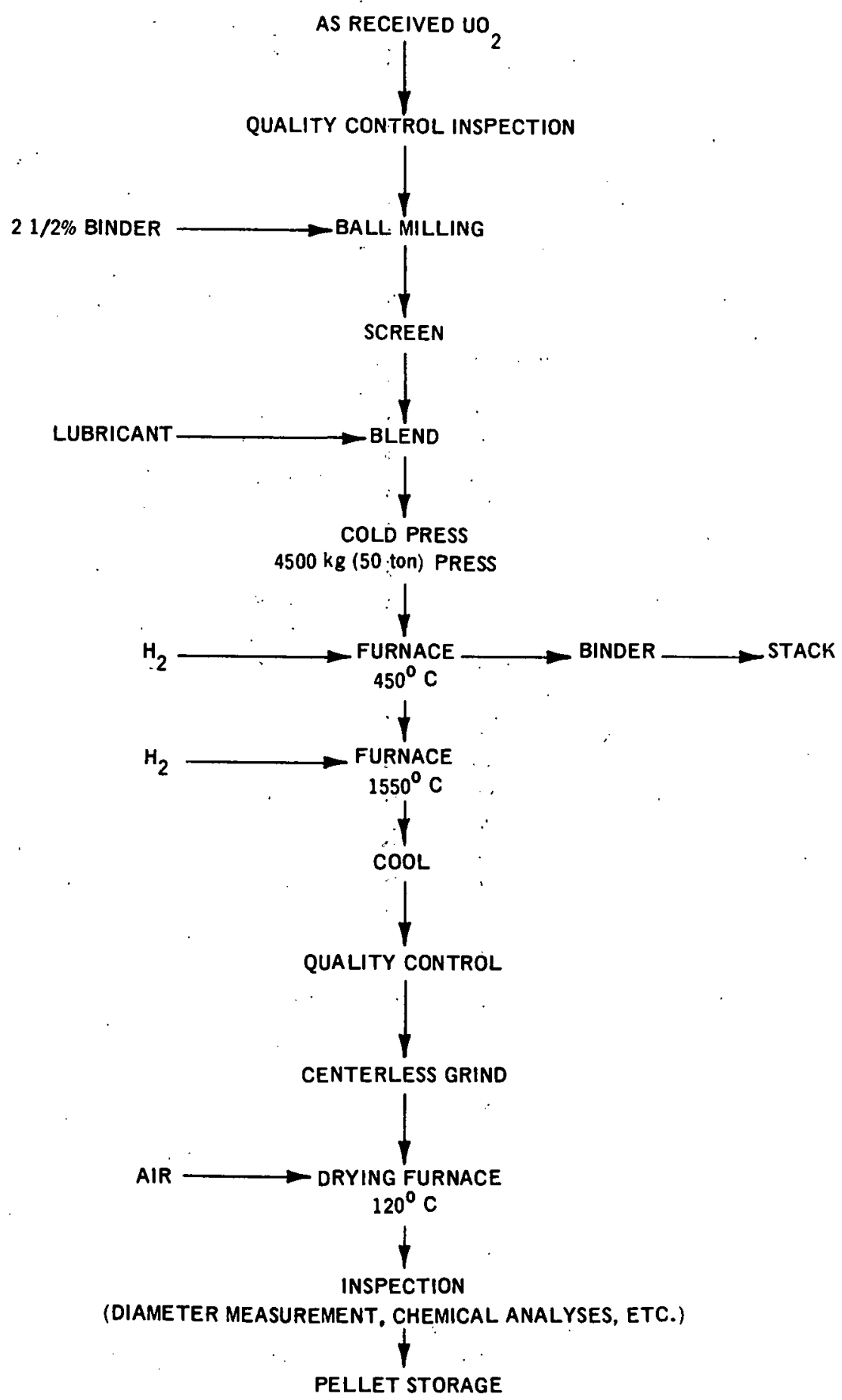

Figure 11. Flow Diagram for Preparation of $\mathrm{UO}_{2}$ Pellets 
Table 7

PELLET DENSITY AND MOISTURE ANALYSIS

\begin{tabular}{|c|c|c|c|c|c|c|c|}
\hline \multirow{3}{*}{$\begin{array}{l}\text { Pellet } \\
\text { Boat Card } \\
\text { Number }\end{array}$} & \multirow{3}{*}{$\begin{array}{l}\text { Powder } \\
\text { Lot }\end{array}$} & \multirow{3}{*}{$\begin{array}{l}\text { Enrichment } \\
\% \text { U-235 }\end{array}$} & \multicolumn{4}{|c|}{$\begin{array}{l}\text { As-Sintered } \\
\text { Pellet Density }\end{array}$} & \multirow{3}{*}{$\begin{array}{c}\text { Moisture } \\
\text { After Drying } \\
\text { mg/Pellet }\end{array}$} \\
\hline & & & \multirow{2}{*}{$\begin{array}{c}\text { Number of } \\
\text { Samples/Total }\end{array}$} & \multicolumn{3}{|c|}{ \% Theoretical } & \\
\hline & & & & Minimum & Maximum & Average & \\
\hline 1186 & $\mathrm{JO} \mathrm{HB}$ & 2.7 & $25 / 1080$ & 94.4 & 96.2 & 95.3 & 0.12 \\
\hline 1187 & $\mathrm{JO} 3 \mathrm{HB}$ & 2.7 & $25 / 1014$ & 94.3 & 96.2 & 95.4 & 0.24 \\
\hline 1189 & $\mathrm{JO} H \mathrm{HB}$ & 2.7 & $25 / 1084$ & 94.3 & 95.3 & 94.8 & \\
\hline 1199 & $\mathrm{JO} 3 \mathrm{HB}$ & 2.7 & $25 / 1312$ & 94.1 & 96.0 & 95.1 & 0.45 \\
\hline 1601 & JO3HB & 2.7 & $26 / 1080$ & $05: 0$ & 06.1 & 86.7 & 0.16 \\
\hline 1620 & JO5HB & 2.7 & $25 / 1152$ & 94.7 & 97.3 & 96.0 & \\
\hline 1633 & JO4HC & 3.2 & $25 / 1176$ & 94.0 & 96.6 & 95.2 & 0.19 \\
\hline 1640 & JO5HB & 2.7 & $25 / 1080$ & 95.5 & 96.6 & 96.0 & \\
\hline 1642 & JO5HB & 2.7 & $25 / 1080$ & 95.1 & 96.8 & 96.0 . & \\
\hline 2645 & J01DD & 3.5 & $10 / 360$ & 94.3 & 95.3 & 94.8 & \\
\hline 2646 & J01DD & 3.5 & $10 / 345$ & 94.2 & 95.1 & 94.7 & 0.27 \\
\hline 2647 & J01DD & 3.5 & $10 / 500$ & 92.8 & 94.7 & 94.0 & \\
\hline 2648 & J01DD & 3.5 & $10 / 500$ & 92.3 & 94.4 & 93.5 & \\
\hline 2649 & JO2DD & 3.5 & $10 / 500$ & 92.7 & 95.2 & 94.0 & \\
\hline 2650 & JO2DD & 3.5 & $10 / 500$ & 94.2 & 94.9 & 94.6 & 0.27 \\
\hline 2651 & $\mathrm{JO} 2 \mathrm{DD}$ & 3.5 & $10 / 500$ & 94.5 & 95.5 & 95.0 & \\
\hline 2652 & $122360-6$ & 3.5 & $10 / 536$ & 92.5 & 95.2 & 94.0 & \\
\hline 2653 & $122360-6$ & 3.5 & $10 / 539$ & 94.0 & 95.3 & 94.7 & \\
\hline 2654 & JO2DD & 3.5 & $15 / 571$ & 94.0 & 94.7 & 94.4 & 0.27 \\
\hline
\end{tabular}


The final pellet diameter was $0.955_{-0.008}^{+0.000} \mathrm{~cm}\left(0.376_{-0.003}^{+0.000}\right.$ in.). The length of the $2.7 \%$ and $3.2 \%$ enriched pellets was $1.5 \mathrm{~cm}(0.6 \mathrm{in}$.$) and that of the 3.5 \%$ enriched pellets was 2.2 to $2.4 \mathrm{~cm}(0.85$ to 0.95 in.). The first 10 pellets from each boat processed through the grinding operation were checked for diameter. If all 10 were acceptable, the grinding operation was continued, and every tenth pellet was checked. If a sample pellet was out of specification. sequential sampling was retained or restored until control of the operation was established.

All pellets were visually inspected after grinding to determine their physical condition. A pellet was rejected if its cylindrical surface showed an unground region that caused the pellet diameter there to be less than specified. Any pellet that was chipped or chamfered to such a degree that the missing volume of $\mathrm{UO}_{2}$ was estimated to be greater than that shown by any of the examples in Figure 12 was not accepted. The "missing chip" volumes depicted by the several examples are approximately equivalent. Any pellet that contained a surface crack wider than $0.0076 \mathrm{~cm}(0.003$ in.) was rejected.

Sample pellets were selected for moisture analysis as each batch was removed from the drying oven. These analyses are presented in Table 7, along with the pellet density data. Each of the shorter pellets weighed 11 to $12 \mathrm{gm}$ and each of the longer weighed 16 to $17 \mathrm{gm}$.

Samples of the finished pellets were analyzed for enrichment. O/U ratio, concentrations of impurities, and neutron cross-section factor. Chemical analysis of sample pellets representing most of the various powder lots are given in Table 6.

All finished pellets were stored on trays that were sealed in plastic bags containing a desicant until the pellets were loaded into fuel tubes.

\subsection{ROD FABRICATION}

After all of the component parts had been manufactured, the fuel rods were assembled as described below and diagramed in Figure 13.

A. The first end plugs (Dwg. No. 145A5394) were inserted into the tubes. The tubes and plugs were placed in a vacuum-type welding chamber. The chamber was evacuated and then backfilled with helium to a pressure of 1 atmosphere. The end plugs were welded to the tubes with a heliarc torch equipped with tungsten electrodes. The tubes were supported in a horizontal position and rotated during the welding process. The controls of the welding machine were preset to give a start, weld, and stop cycle.

B. The tubes with first end plugs welded in place were removed from the chamber. The $\mathrm{UO}_{2}$ pellets were loaded into the fuel tubes, and the wafers and plenum support tubes were inserted. The weight of $\mathrm{UO}_{2}$ loaded and the fuel column length were measured and recorded for each rod. These values are listed in Table 8 for the SA-1 fuel rods.

The diameter of each pellet and its relative position in the fuel column were recorded and available for six of the SA-1 rods. This information is given in Appendix $C$.

C. The loaded tubes and second end plugs (Dwg. No. 145A5393) were placed in the welding chamber. The chamber was evacuated to 0.07 micron and held at this pressure for 15 minutes by continuous pumping. The chamber then was rapidly backfilled with helium to a pressure of 1 atmosphere. The end plugs were inserted into the tube ends and welded in a manner similar to that described in paragraph $A$ above.

The welding parameters for each type of end plug were accepted for production use when they had provided 10 consecutive satisfactory welds, as determined by metallographic examination of end plug sections showing penetration through the tube wall. The welding current was recorded for each production weld and compared to the trace obtained during qualification. It was required that the production traces fall within the limits shown on the qualification trace.

Each production weld was visually inspected for completeness and for the presence of any undercutting or blow holes.

Each weld was $x$-rayed to inspect for complete penetration and the absence of porosity. A $0.025 \mathrm{~cm}(0.010 \mathrm{in}$. thick Zircaloy penetrameter that contained a $0.025 \mathrm{~cm}$ diameter hole was included in each exposure. Two exposures were taken of each weld. The rod was rotated 90 -degrees between exposures. The second end plug weld $x$-ray included the entire plenum area to assure that the wafer and support tube were properly in place.

After the welds were $x$-rayed each fuel rod was wiped down with alcohol and leak tested with a helium mass spectrometer leak detector. The sensitivity of the spectrometer was set to detect a $1 \times 10^{-8} \mathrm{~cm}^{3} / \mathrm{sec} \mathrm{standard}$ helium leak. 
Table 8

PRE-IRRADIATION DATA ON SA-1 FUEL RODS

\begin{tabular}{|c|c|c|c|c|c|c|c|c|c|c|c|}
\hline $\begin{array}{l}\text { SA-1 } \\
\text { Number }\end{array}$ & $\begin{array}{l}\text { Fabrication } \\
\text { Number }\end{array}$ & $\begin{array}{l}\text { Specified } \\
\text { Uranium } \\
\text { Enrichment } \\
(\% \text { U.235) }\end{array}$ & $\begin{array}{l}\text { Pellet } \\
\text { Boat Card } \\
\text { Number }\end{array}$ & $\begin{array}{l}\text { Weight } \\
U_{2} \\
\text { (grams) }\end{array}$ & $\begin{array}{l}\text { Fuel } \\
\text { Column } \\
\text { Length } \\
\text { (cm lin.1) }\end{array}$ & $\begin{array}{l}\text { Tubing } \\
\text { Lot Number }\end{array}$ & Bottom* & $\begin{array}{l}\text { Diameter (cm [in.]) } \\
\text { Middle }\end{array}$ & Top* & Remát & arks \\
\hline A1 & R2D7 & 2.7 & 1187 & 693 & $93.74(36-29 / 32)$ & CA-2 & $1.080(0.425)$ & $1.081(0.4255)$ & $1.081(0.4255)$ & & \\
\hline A2 & R1D30 & 2.7 & 1620 & 700 & $94.22(37-3 / 32)$ & CA-1 & $1.077(0.424)$ & $1.078(0.4245)$ & $1.077(0.424)$ & Circumferential marks fr & from ultrasonic testing. \\
\hline A3 & R5D 10 & 2.7 & 1199 & 693 & $94.14(37 \cdot 1 / 16)$ & CA-5 & $1.073(0.4225)$ & $1.074(0.423)$ & $1.074(0.423)$ & & \\
\hline A4 & R5D 13 & 2.7 & .1199 & 693 & $93.98(37)$ & CA.5 & $1.074(0.423)$ & $1.072(0.422)$ & $1.072(0.422)$ & & 1 \\
\hline A5 & R2D8 & 2.7 & 1640 & 702 & $94.06(37-1 / 32)$ & $\mathrm{CA}-2$ & $1.081(0.4255)$ & 1.081 (n 4255) & 1 ก81 (n 4255$)$ & & $?$ \\
\hline$A G$ & R5D24 & 2.7 & 1804 & 694 & $94.22(37-3 / 32)$ & CA.5 & $1.077(0.424)$ & $1.080(0.425)$ & $1.077(0.424)$ & & $!$ \\
\hline A7 & R5D29 & 2.7 & 1604 & 694 & $94.14(37-1 / 16)$ & CA-5 & $1.071(0.4215)$ & $1.072(0.422)$ & $1.073(0.4225)$ & & 1 \\
\hline$A B$ & R104 & 2.7 & 1189 & 888 & $94.14(37-1 / 16)$ & CA-1 & $1.077(0.424)$ & $1.077(0.424)$ & $1.081(0.4225)$ & Circumferential marks $\mathrm{fr}$ & from ultrasonic testing. \\
\hline A9 & R2D80 & 3.5 & $2645 / 2650$ & 693 & $93.98(37)$ & CA-2 & $1.080(0.425)$ & $1.082(0.426)$ & $1.080(0.425)$ & & \\
\hline A10 & R2D69 & 3.2 & 1633 & 696 & $94.14(37-1 / 16)$ & CA-2 & $1.082(0.426)$ & $1.082(0.426)$ & $1.082(0.426)$ & & \\
\hline A11 & R4D5 & 3.5 & $2647 / 2649^{\circ}$ & 687 & $94.14(37 \cdot 1 / 16)$ & CAA & $1.074(0.423)$ & $1.074(0.423)$ & $1.074(0.423)$ & & \\
\hline A12 & R3D5 & 3.2 & 1633 & 696 & $93.98(37)$ & CA.3 & $1.080(0.425)$. & $1.080(0.425)$ & $1.080(0.425)$ & & \\
\hline A13 & R2D93 & 3.5 & $2646 / 2649$ & 693 & $94.06(37-1 / 32)$ & CA-2 & $1.082(0.426)$ & $1.082(0.426)$ & $1.081(0.4255)$ & & \\
\hline A14 & R2D4 & 2.7 & 1187 & 693 & $93.74(36.29 / 32)$ & CA-2 & $1.081(0.4255)$ & $1.081(0.4255)$ & $1.080(0.425)$ & & $!$ \\
\hline A15 & R5D2 & 2.7 & 1199 & 696 & $94.46(37 \cdot 3 / 16)$ & CA-5 & $1.077(0.424)$ & $1.077(0.424)$ & $1.077(0.424)$ & & \\
\hline A16 & R2D76 & 3.2 & 1633 & 696 & $94.22(37-3 / 32)$ & CA.2 & $1.082(0.426)$ & $1.082(0.426)$ & $1.082(0.426)$ & & 1 \\
\hline A17 & R2D71 & 3.5 & 2651 & 689 & $94.06(37.1 / 32)$ & CA-2 & $1.081(0.4255)$ & $1.081(0.4255)$ & $1.081(0.4255)$ & & I \\
\hline A18 & R4D18 & 3.5 & 2654/2649 & 687 & $93.82(36.15 / 16)$ & CA-4 & $1.076(0.4235)$ & $1.074(0.423)$ & $1.076(0.4235)$ & & \\
\hline A19 & R1067 & 3.5 & $2653 / 2648$ & 688 & $94.06(37-1 / 32)$ & CA-1 & $1.072(0.422)$ & $1.073(0.4225)$ & $1.073(0.4225)$ & & $i$ \\
\hline A20 & R2D78 & 3.2 & 1633 & 687 & $93.82(36-15 / 16)$ & CA-2 & $1.082(0.426)$ & $1.081(0.4255)$ & $1.082(0.426)$ & $\left\{\begin{array}{l}\text { Gold-colored weld } \\
\text { Bowed } 0.229 \mathrm{~cm} 10.090\end{array}\right.$ & $\begin{array}{l}i \\
\text { i in.) - straightened }\end{array}$ \\
\hline A21 & R2D11 & 2.7 & 1640 & 699 & $93.74(36 \cdot 29 / 32\}$ & CA-2 & $1.080(0.425)$ & $1.081(0.425)$ & $1.080(0.425)$ & & \\
\hline A22 & R5D9 & 2.7 & 1199 & 690 & $93.82(36-15 / 16)$ & CA. 5 & $1.077(0.424)$ & $1.077(0.424)$ & $1.077(0.424)$ & & 1 \\
\hline A23 & R4D3 & 3.5 & $2647 / 2649$ & 686 & $94.06(37.1 / 32)$ & CA-4 & $1.077(0.424)$ & $1.077(0.424)$ & $1.077(0.424)$ & & \\
\hline A24 & R4D23 & 3.5 & $2647 / 2649$ & 689 & $94.06(37.1 / 32)$ & $C A-4$ & $1.076(0.4235)$ & $1.076(0.4235)$ & $1.076(0.4235)$ & & 1 \\
\hline A25 & R2D77 & 3.2 & 1633 & 696 & $94.06(37-1 / 32)$ & $\mathrm{CA} \cdot 2$ & $1.081(0.4255)$ & $1.082(0.426)$ & $1.082(0.426)$ & & 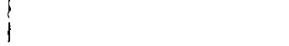 \\
\hline A26 & RAD8 & 3.5 & $2654 / 2648$ & 689 & $93.82(36-15 / 16)$ & CA.4 & $1.077(0.424)$ & $1.076(0.4235)$ & $1.078(0.4245)$ & & \\
\hline A27 & R2D75 & 3.5 & $2645 / 2650$ & 692 & $\cdots-$ & CA-2 & $1.081(0.4255)$ & $1.082(0.426)$ & $1.083(0.4265)$ & & ; \\
\hline A28 & R2D16 & 2.7 & 1640 & 703 & $93.98(37)$ & CA-2 & $1.082(0.426)$ & $1.082(0.426)$ & $1.081(0.4255)$ & & 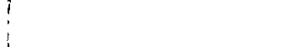 \\
\hline A29 & R2D5 & 2.7 & 1640 & 701 & $93.90(36-31 / 32)$ & CA-2 & $1.082(0.426)$ & $1.082(0.426)$ & $1.082(0.426)^{\circ}$ & & 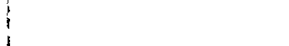 \\
\hline A30 & R2D73 & 3.2 & 1633 & 688 & $93.82(36-15 / 16)$ & CA-2 & $1.082(0.426)$ & $1.082(0.426)$ & $1.081(0.4255)$ & 1 & I \\
\hline A31 & R1D72 & 3.5 & $2654 / 2648$ & 684 & $93.30(36-31 / 32)$ & CA-1 & $1.078(0.4245)$ & $1.077(0.424)$ & $1.078(0.4245)$ & & \\
\hline A32 & R4D 12 & 3.5 & $2654 / 2649$ & 691 & $94.06(37-1 / 32)$ & $\mathrm{CA}-4$ & $1.077(0.424)$ & $1.080(0.425)$ & $1.080(0.425)$ & & \\
\hline A33 & R3D4 & 3.2 & 1633 & 697 & $94.22(37-3 / 32)$ & $\mathrm{CA}-3$ & $1.076(0.4235)$ & $1.074(0.423)$ & $1.081(0.4255)$ & & $!$ \\
\hline A34 & R2D79 & 3.2 & 1633 & 694 & $93.82(36-15 / 16)$ & CA-2 & $1.078(0.4245)$ & $1.080(0.426)$ & $1.080(0.425)$ & Gold-colored weld & 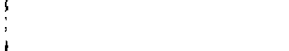 \\
\hline A35 & R2D1 & 2.7 & 1187. & 693 & $93.90(36-31 / 32)$ & $C A-2$ & $1.077(0.424)$ & $1.077(0.424)$ & $1.080(0.425)$ & a & 1 \\
\hline A36 & R5L & 2.7 & 1604 & 694 & $94.14(37-1 / 16)$ & $C A-5$ & $1.077(0.424)$ & $1.078(n$ ( 4245) & $1.077(0.420)$ & & \\
\hline A37 & R1D & 3.5 & 2653/2648 & 686 & $93.90(36-31 / 32)$ & CA.1 & $1.077(0.424)$ & $1.080(0.425)$ & $1.080(0.4245)$ & & \\
\hline A 38 & $\mathrm{R} 3 \mathrm{DO} 3$ & 3.2 & 1633 & 695 & $93.82(36-15 / 16)$ & $\mathrm{CA}-3$ & $1.080(0.425)$ & $1.077(0.424)$ & $1.080(0.425)$ & & ti \\
\hline A39 & R4D11 & 3.5 & $2650 / 2649$ & 688 & $93.82(36.15 / 16)$ & $\mathrm{CA}-4$ & $1.074(0.423)$ & $1.074(0.423)$ & $1.076(0.4235)$ & & 1 \\
\hline A40 & $\mathrm{R} 3 \mathrm{D} 2$ & 3.2 & 1633 & 695 & $93.74(36-29 / 32)$ & $C A-3$ & $1.077(0.424)$ & i'.077 (0.424) & $1.077(0.424)$ & & 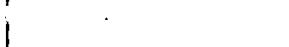 \\
\hline A41 & R6D 14 & 3.5 & 2645 & 689 & $93.90(36-31 / 32)$ & CA.4 & 1.076 (0.4235) & $1.076(0.4235)$ & $1.078(0.4245)$ & & \\
\hline A42 & R2D40 & 2.7 & 1186 & 691 & 93.98 (37) & CA-2 & $1.082(0.426)$ & $1.081(0.4255)$ & $1.082(0.426)$ & Minor scratches. & \\
\hline A43 & $\mathrm{R} 5 \mathrm{D} 28$ & 2.7 & 1604 & 692 & $94.06(37-1 / 32)$ & CA-5 & $1.077(0.424)$. & $1.077(0.424)$ & $1.074(0.423)$ & & \\
\hline A44 & R2D 15 & 2.7 & 1187 & 695 & $93.90(36.31 / 32)$ & CA-2 & $1.077(0.424)$ & $1.076(0.4235)$ & $1.077(0.424)$ & & \\
\hline
\end{tabular}




\begin{tabular}{|c|c|c|c|c|c|c|c|c|c|c|}
\hline $\begin{array}{l}\text { SA-1 } \\
\text { Number }\end{array}$ & $\begin{array}{l}\text { Fabrication } \\
\text { Number }\end{array}$ & $\begin{array}{c}\text { Specified } \\
\text { Uranium } \\
\text { Enrichment } \\
\text { (\% U-235) }\end{array}$ & $\begin{array}{l}\text { Pellet } \\
\text { Boat Card } \\
\text { Number }\end{array}$ & $\begin{array}{c}\text { Weight } \\
\mathrm{UO}_{2} \\
\text { (grams) }\end{array}$ & $\begin{array}{c}\text { Fuel } \\
\text { Column } \\
\text { Length } \\
\text { (cm [in.]) }\end{array}$ & $\begin{array}{c}\text { Tubing } \\
\text { Lot Number }\end{array}$ & Bottom* & $\begin{array}{l}\text { Rod Diameter (cm lin.]) } \\
\text { Middle }\end{array}$ & Top* & Remarks \\
\hline A45 & R2D24 & 2.7 & 1640 & 703 & $94.06(37.1 / 32)$ & CA-2 & $1.081(0.4255)$ & $1.081(0.4255)$ & $1.081(0.4255)$ & \\
\hline A46. & R2D10 & 2.7 & 1640 & 702 & $94.06(37.1 / 32)$ & CA-2 & $1.080(0.425)$ & $1.080(0.425)$ & $1.080(0.425)$ & \\
\hline A47 & R2D34 & 2.7 & 1186 & 688 & $93.90(36-31 / 32)$ & CA-2 & $1.080(0.425)$ & $1.080(0.425)$ & $1.082(0.426)$ & Minor scratches. \\
\hline A48 & R2D43 & 2.7 & 1189 & 688 & $93.98(37)$ & CA-2 & $1.082(0.426)$ & $1.082(0.426)$ & $1.082(0.426)$ & Minor scratches; Slightly gold-colored weld. \\
\hline A49 & R2D45 & 2.7 & 1186 & 692 & $93.90(36-31 / 32)$ & CA.2 & $1.080(0.425)$ & $1.078(0.4245)$ & $1.080(0.425)$ & Minor scratches; Slightly gold-colored weld. \\
\hline 850 & R2D25 & 2.7 & 1640 & 702 & $94.06(37-1 / 32)$ & CA-2 & $1.080(0.425)$ & $1.080(0.425)$ & $1.080(0.425)$ & \\
\hline 851 & R1D3 & 2.7 & 1189 & 689 & $94.14(37-1 / 16)$ & CA-1 & $1.074(0.423)$ & $1.076(0.4235)$ & $1.077(0.424)$ & Circumferential,marks from ultrasonic testing \\
\hline 852 & $\mathrm{R} 2 \mathrm{D} 23$ & 2.7 & 1640 & 704 & $94.14(37.1 / 76)$ & CA.2 & $1.080(0.425)$ & $1.078(0.4245)$ & $1.078(0.4245)$ & \\
\hline 853 & R2O22. & 2.7 & 1640 & 700 & $93.90(36-31 / 32)$ & CA-2 & $1.081(0.4255)$ & $1.082(0.426)$ & $1.082(0.426)$ & \\
\hline 854 & R2D14 & 2.7 & 1640 & 702 & $94.06(37-1 / 32)$ & $C A-2$ & $1.080(0.425)$ & $1.080(0.425)$ & $1.080(0: 425)$ & \\
\hline 855 & R5D19 & 2.7 & 1604 & $694^{\circ}$ & $94.30(37-1 / 8)$ & CA-5 & $1.073(0.4225)$ & $1.072(0.422)$ & $1.073(0.4225)$ & \\
\hline $856^{\circ}$ & $\mathrm{R} 2 \mathrm{D} 32$ & 2.7 & 1186 & 692 & $93.98(37)$ & CA.2 & $1.082(0.426)$ & $1.078(0.4245)$ & $1.080(0.425)$ & Minor scratches; Slightly gold-colored weld. \\
\hline 857 & R1033 & 2.7 & 1642 & 698 & $93.90(36-31 / 32)$ & CA-1 & $1.077(0.424)$ & $1.080(0.425)$ & $1.077(0.424)$ & Circumferential marks from ultrasonic testing \\
\hline 858 & R2D64 & 3.5 & 2651 & 688 & $93.90(36-31 / 32)$ & CA-2 & $1.081(0.4255)$ & $1.082(0.426)$ & $1.081(0.4255)$ & \\
\hline 859. & R2D65 & 3.2 & 1633 & 693 & $93.98(37)^{\circ}$ & CA.2 & $1.080(0.425)$ & $1.080(0.425)$ & $1.080(0.425)$ & \\
\hline 860 . & R4D2: & 3.5 . & $2650 / 2649$ & 686 & $93.82(36.15 / 16)$ & CA-4 & $1.077(0.424)$ & $1.077(0.424)$ & $1.077(0.424)$ & \\
\hline B61 & R2D70 & 3.2 & 1633 & 694 & $94.22(37 \cdot 3 / 32)$ & CA-2 & $1.083(0.4265)$ & $1.083(0.4265)$ & $1.082(0.426)$ & \\
\hline 862 & R1075 & 3.5 & $2653 / 2648$ & 687 & $94.14(37-1 / 16)$ & CA.1 & $1.078(0.4245)$ & $1.077(0.424)$ & $1.077(0.424)$ & \\
\hline 863 & R5026 & 2.7 & 1604 & 694 & $94.14(37-1 / 16)$ & CA-5 & $1.074(0.423)$ & $1.074(0.423)$ & $1.077(0.424)$ & \\
\hline 864 & $\begin{array}{l}\text { R2D17. } \\
\text { R2D }\end{array}$ & 2.7 & 1640 & 704 & $93.98(37)$ & CA-2 & $1.076(0.4235)$ & $1.078(0.4245)$ & $1.078(0.4245)$ & \\
\hline 865 & R2D68 & 3.2 & 1633 & 697 & $94.06(37-1 / 32)$ & CA.2 & $1.077(0.424)$ & $1.077(0.424)$ & $1.078(0.4245)$ & \\
\hline 866 & R4013 & 3.5 & $2654 / 2649$ & 689 & $93.90(36-31 / 32)$ & CA4 & $1.077(0.424)$ & $1.074(0.423)$ & $1.077(0.424)$ & \\
\hline 867 & R2D98 & 3.5 & 2645 & 691 & $93.82(36-15 / 16)$ & CA.2 & $1.077(0.424)$ & $1.077(0.424)$ & $1.077(0.424)$ & \\
\hline 868 & R2D72. & 3.5 & $2651 / 2645$ & 693 & $93.98(37)$ & CA.2 & $1.082(0.426)$ & $1.081(0.4255)$ & $1.081(0.4255)$ & \\
\hline 869 & R3D8. & 3.2 & 1633 & 693 & $93.74(36-29 / 32)$ & $\mathrm{CA}-3$ & $1.076(0.4235)$ & $1.074(0.423)$ & $1.078(0.4245)$ & \\
\hline B70 & R5D15 & $2.7^{\circ}$ & 1199 & 694 & $94: 14(37 \cdot 1 / 16)$ & CA.5 & $1.080(0.425)$ & $1.078(0.4245)$ & $1.074(0.423)$ & \\
\hline B71 & R2D18 & 2.7 & 1187 & 697 & $94.30(37-1 / 8)$ & CA.2 & $1.082(0.426)$ & $1.082(0.426)$ & $1.082(0.426)$ & \\
\hline B72 & R1D68 & 3.5 & $2653 / 2648$ & 685 & $94.06(37-1 / 32)$ & CA-1 & $1.080(0.425)$ & $1.080(0.425)$ & $1.080(0.425)$ & \\
\hline B73 & $R 407$ *" & 3.5 & $2650 / 2649$ & $695^{\circ}$ & $93.98(37)$ & CA-4 & $1.077(0.424)$ & $1.076(0.4235)$ & $1.076(0.4235)$ & \\
\hline B74. & R2D62 & 3.2 . & 1633 & 694 & $93.98(37)$ & CA-2 & $1.077(0.424)$ & $1.080(0.425)$ & $1.080(0.425)$ & \\
\hline B75 & R4D9 & 3.5 & $2654 / 2649$ & 687 & $93.98(37)$ & CA.4 & $1.078(0.4245)$ & $1.077(0.424)$ & $1.080(0.425)$ & \\
\hline 876 & R2D86 & 3.5 & $2646 / 2649$ & 690 & $93.90(36-31 / 32)$ & CA.2 & $1.082(0.426)$ & $1.080(0.425)$ & $1.080(0.425)$ & \\
\hline B77. & R5D7 & 2.7 & 1199 & 689 & $93.98(37)$ & CA. 5 & $1.074(0.423)$ & $1.076(0.4235)$ & 1.076 (0.4235) & \\
\hline B78 & R2D9 & 2.7 & 1640 & 702 & $94.14(37-1 / 16)$ & $C A \cdot \dot{2}$ & $1.081(0.4255)$ & $1.081(0.4255)$ & $1.081(0.4255)$ & \\
\hline B79 & R2D61 & 3.2 & 1633 & 692 & $93.90(36-31 / 32)$ & CA-2 & $1.082(0.426)$ & $1.082(0.426)$ & $1.082(0.426)$ & \\
\hline$B 80$ & R2D91. & 3.5 & 2651 & 692 & $94.06(37-1 / 32)$ & CA.2 & $1.082(0.426)$ & $1.080(0.425)$ & $1.078(0.4245)$ & \\
\hline B81. & R4D14 & $\begin{array}{l}3.5 \\
3.5\end{array}$ & $2647 / 2649$ & (687 & $93.98(37)$ & CA- & $1.073(0.4225)$ & $1.073(0.4225)$ & $1.073(0.4225)$ & \\
\hline B82 & R3D6:: & 3.2 & 1633 & 695 & $93.74(36-29 / 32)$ & CA.3 & $1.076(0.4235)$ & $1.076(0.4235)$ & $1.074(0.423)$ & \\
\hline B83 & R3D 10 & 3.2 & 1633 & 697 & $94.06(37-1 / 32)$ & CA.3 & $1.074(0.423)$ & $1.074(0.423)$ & $1.076(0.4235)$ & \\
\hline B84 & R2D 31 . & 2.7 & 1187 & 692 & $93.82(36-15 / 16)$ & CA-2 & $1.080(0.425)$ & $1.080(0.425)$ & $1.081(0.4255)$ & Minor scratches. \\
\hline 885 & R5D 18 & 2.7 & 1604 & 694 & & CA. 5 & $1.080(0.425)$ & $1.078(0.4245)$ & $1.077(0.424)$ & \\
\hline 886. & R1D74 & 3.5 & $2652 / 2648$ & 682 & $94.30(37-1 / 8)$ & CA-1 & $1.077(0.424)$ & $1.077(0.424)$ & $1.077(0.424)$ & \\
\hline 887. & R3D7 & 3.2 & 1633 & 694. & $93.74(36-29 / 32)$ & $\mathrm{CA}-3$ & $1.077(0.424)$ & $1.077(0.424)$ & $1.074(0.423)$ & \\
\hline 888 & R2D92 & 3.5 & 2651 & 690 & $94.06(37-1 / 32)$ & CA-2 & 1.076 (0.4235) & $1.077(0.424)$ & $1.077(0.424)$ & \\
\hline
\end{tabular}




\begin{tabular}{|c|c|c|c|c|c|c|c|c|c|c|}
\hline \multirow{4}{*}{$\begin{array}{l}\text { SA-1 } \\
\text { Number }\end{array}$} & \multicolumn{10}{|c|}{ Table 8 (Continued) } \\
\hline & & $\begin{array}{l}\text { Specified } \\
\text { Uranium }\end{array}$ & Pellet & & $\begin{array}{l}\text { Fuel } \\
\text { Column }\end{array}$ & & & & & . \\
\hline & Fabrication & Enrichment & Boat Card & $\mathrm{VO}_{2}$ & Length & Tubing & & iameter (cm [in.]) & & \\
\hline & Number & (\% U-235) & Number & (grams) & $(\mathrm{cm}[\mathrm{in}])$. & Lot Number & Bottom* & Middle & Top* & Remarks \\
\hline B89 & R309 & 3.2 & 1633 & 696 & $94.00(37-1 / 32)$ & CA-3 & $1.076(0.4235)$ & $1.078(0.4245)$ & $1.078(0.4245)$ & Gold-colored weld. \\
\hline B90 & R1069 & 3.5 & $2652 / 2648$ & 682 & $94.30(37-1 / 8)$ & CA-1 & $1.076(0.4235)$ & $1.076(0.4235)$ & $1.077(0.424)$ & \\
\hline$B 91$ & R2D51 & 2.7 & 1186 & 690 & $93.82(36-15 / 16)$ & CA.2. & $1.078(0.4245)$ & $1.080(0.425)$ & $1.080(0.425)$ & Slightly gold-colored weld. \\
\hline 892 & R2D33 & 2.7 & 1187 & 693 & $93.90(36-31 / 32)$ & $C A \cdot 2$ & $1.081(0.4255)$ & $1.080(0.425)$ & $1.080(0.425)$ & Minor scratches. \\
\hline B93 & R5D23 & 2.7 & 1604 & 695 & $94: 14(37-1 / 16)$ & CA. 5 & $1.076(0.4235)$ & $1.077(0.424)$ & $1.077(0.424)$ & \\
\hline$B 94$ & R5022 & 2.7 & 1604 & 696 & $94.14(37-1 / 16)$ & CA. 5 & $1.074(0.423)$ & $1.076(0.4235)$ & $1.077(0.424)$ & \\
\hline 895 & R5020 & 2.7 & 1604 & 694 & $94.14(37-1 / 16)$ & CA.5 & $1.077(0.424)$ & $1.078(0.4245)$ & 1.078 (0.4245) & \\
\hline 896 & R2052 & 2.7 & 1187 & 692 & $93.98(37)$ & CA-2 & $1.077(0.424)$ & $1.078(0.4245)$ & $1.080(0.425)$ & Minor scratches. \\
\hline 897 & R2D46 & 2.7 & 1186 & 693 & $93.98(37)$ & CA-2 & $1.077(0.424)$ & $1.080(0.425)$ & $1.080(0.425)$ & Minor scratches. \\
\hline B98 & R2D 38 & 2.7 & 1189 & 686 & $93.82(36-15 / 16)$ & CA-2 & $1.078(0.4245)$ & $1.080(0.425)$ & $1.081(0.4255)$ & Minor scratches. \\
\hline
\end{tabular}

The "bottom" mcasurcments were those lakkeri liearest the long end plug and plenum of the "A" rods and those taken nearest the short end plug of the " $B$ " rods. 

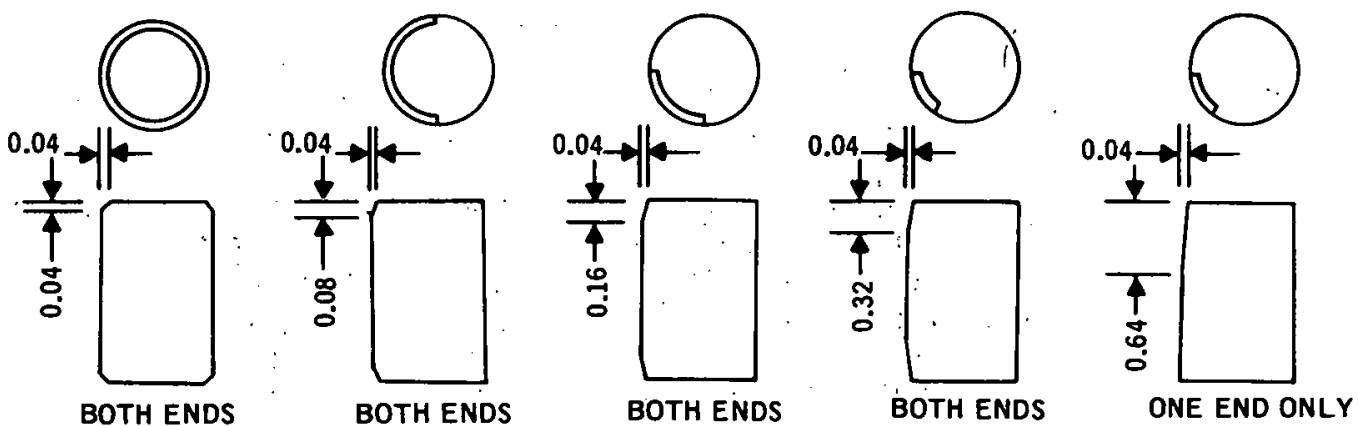

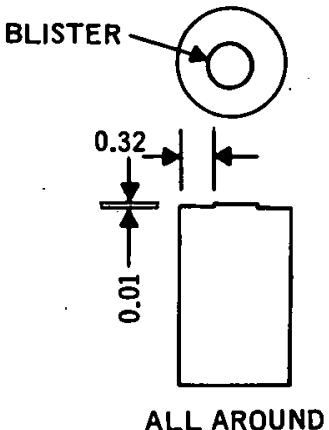

Dimensions are in $\mathrm{cm}$

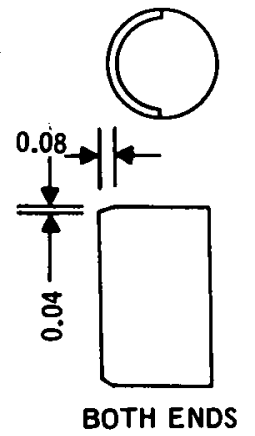

$1 / 2$ AROUND

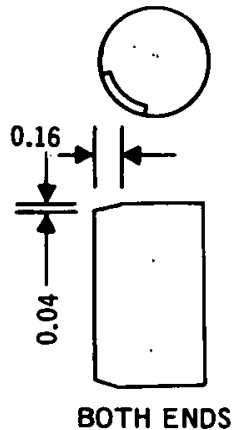

$1 / 4$ AROUND

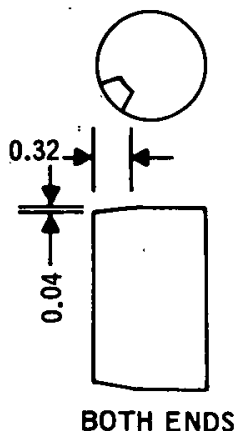

$1 / 8$ AROUND

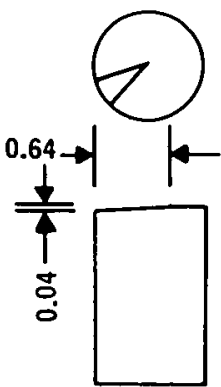

ONE END ONLY

$1 / 8$ AROUND

Figure 12. Maximum Sizes of Chips Allowed in Finished Pellets

Any fucl rod that had a defective weld according to $x$-ray inspection or that had a helium leak $\geqslant 10^{-8} \mathrm{~cm}^{3} / \mathrm{sec}$ was rejected. About $7 \%$ of the fuel rods were rejected by either $x$-ray inspection or helium leak testing. Additional statistics on fuel rod production and yield are given in Table 9.

After the helium leak test, the rods were again ultrasonically cleaned, flushed, rinsed, and dried. Each rod was visually inspecten, and any rod that had a scratch or dent in the tubing estimated to be more than $0.005 \mathrm{~cm}$ (0.002 in.) deep or that was bowed in excess of $0.10 \mathrm{~cm}(0.040 \mathrm{in}$.$) and could not be satisfactorily straightened$ was rejected. The distance between the shoulder of the first end plug and the end of the second plug was measured to the nearest $0.08 \mathrm{~cm}(1 / 32 \mathrm{in.})$ and recorded for each rod, and the diameter of each fuel rod was measured with a micrometer to the nearest $0.0025 \mathrm{~cm}(0.001 \mathrm{in.})$ at three places along the length and recorded. These data are listed in Table 8 for those rods that were later selected for incorporation in Assembly SA-1.

Fuel rods that were not immediately required to make up one of the VBWR Fuel Cycle assemblies were sealed in polyethylene bags until needed. All tools and fixtures used in assembly were made of stainless steel or chrome plated steel, or were coated with a nonmetallic material that contained less than $10 \mathrm{ppm}$ of chlorine or fluorine in any form. The rods were wiped with acetone as they were assembled into bundles. After assembly, the rods were visually inspected to assure that the tubing did not contain any nicks or scratches that exceeded $0.005 \mathrm{~cm}$ in depth. The rods and other parts of each fuel assembly were checked for cleanliness before packing by passing a clean white cloth over their surfaces: 


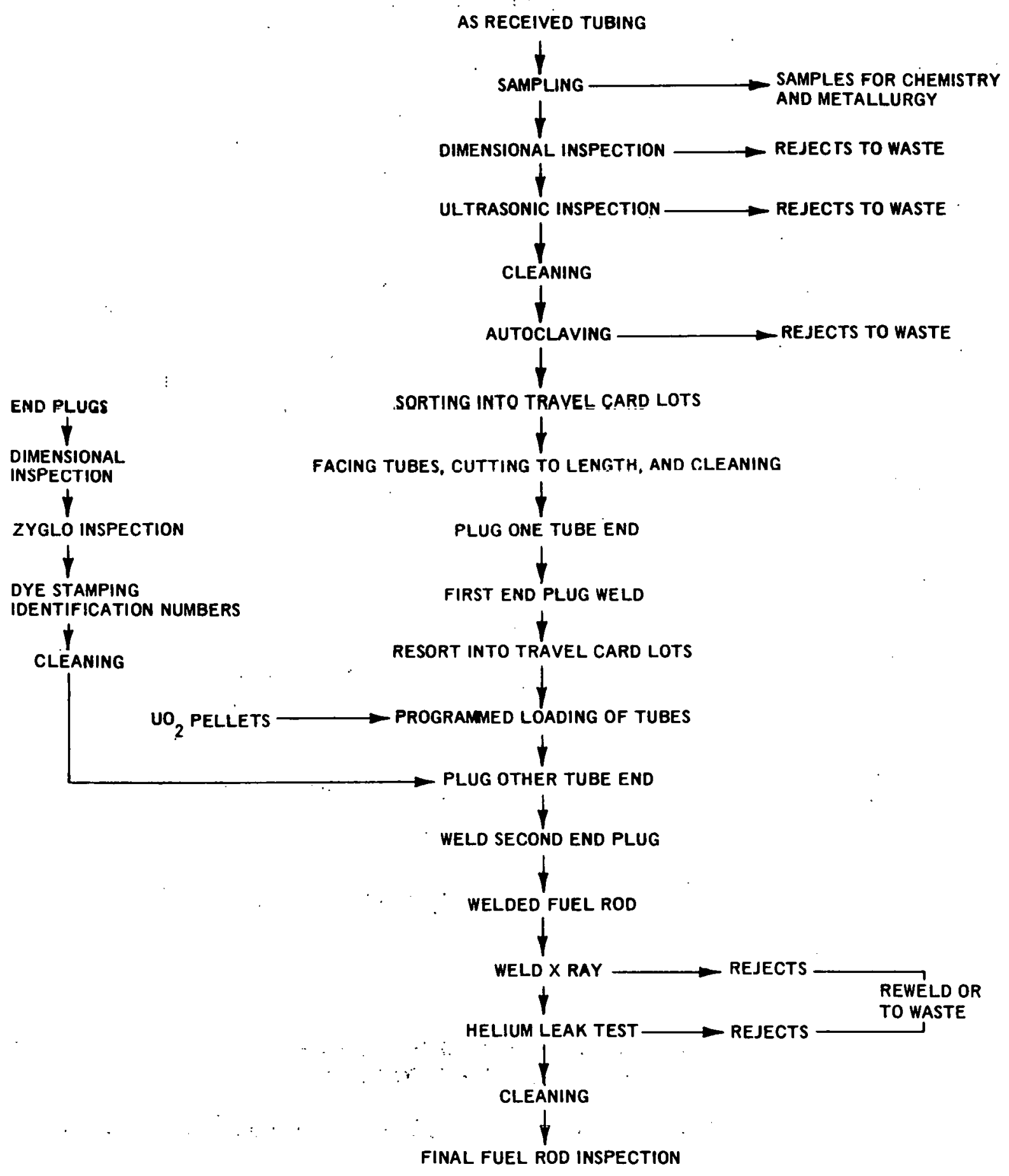

Figure 13. Fuel Rod Fabrication Flow Diagram 
Table 9

\section{FUEL ROD FABRICATION STATISTICS}

Tubes received

Tubes rejected by ultrasonic

Tubes retained for testing

Tubes released to production:

T.ubes lost in production

Tubes made into fuel rods

Fuel rods rejected by $x$-ray or helium leak testing

Acceptable fuel rods
605

33

29

543

95

448

31

417
Percent of tubes released to production which. resulted in acceptable fuel rods

Percent of tubes received which resulted in acceptable fuel rods

Percent of tubes fabricated into fuel rods which were rejected by $x$-ray or helium leak testing. $\frac{(417)}{(543)} \times 100=76.8 \%$

$\frac{(417)}{(605-29)} \times 100=72.4 \%$

$\frac{31 \times 100}{448}=6.9 \%$

\section{LEAK TESTING AND EXAMINATION OF THE TYPE J FUEL AFTER VBWR OPERATION}

The information contained in this section is, for the most part, a summary of procedures and results previously reported in GEAP.4597. ${ }^{2}$

At the terminal shutdown of the VBWR, 23 of the 24 Fuel Cycle Program basic Zircaloy-clad fuel assemblies (Type J) were leak tested by a "wet sipping" technique. The sipping test is performed following a shutdown to detect assemblies in which the cladding has been penetrated, exposing $\mathrm{UO}_{2}$ fuel to the coolant. To perform this test the assembly was sealed in a can and, after it was allowed to soak for about 20 minutes, a 1-liter water sample. was withdrawn. The sample was analyzed for fission product iodine and the concentration compared with the concentration of fission product iodine in the surrounding pool water (background). A higher concentration of radioactive iodine was generally interpreted as being indicative of a fuel rod cladding failure. 
From the results of the sipping tests, four VBWR Type $J$ assemblies were suspected of containing one or more rods with cladding defects. The designations of these assemblies were $7 \mathrm{~J}, 12 \mathrm{~J}, 16 \mathrm{~J}$, and $25 \mathrm{~J}$. The signals from the first three were of relatively low levels, however, and when repeat tests were run on them the indications were too low to be conclusive.

The one Type $\mathrm{J}$ assembly (14J) that was not given a post-irradiation sip test was suspected of containing one or more failed rods on the basis of the activity release detected during earlier incore monitoring.

Upon completion of the sipping, 17 of the assemblies containing 272 fuel rods were transferred from the VBWR fuel storage pool to the Radioactive Materials Laboratory hot cells for examination.

The fuel rod surfaces were generally uniform in appearance and were evenly covered with soft, red-brown crud that had deposited during operation. Two hundred ten of those rods that were easily removable ${ }^{*}$ from their assemblies were individually wiped down with a dry cotton pad to remove most of the crud and were inspected ultrasonically for cladding discontinuities. The rods then were visually inspected with a Kollmorgen periscope. Those areas that showed ultrasonic indications were particularly noted. The removal of the crud deposits revealed a reddish-black surface film which contained numerous shiny specks. About $5 \%$ of the rods inspected had some irregular surface patterns. An example of this mottling can be seen in Figure 14 on rod 14J-12, which later was selected for irradiation in SA-1 as $\operatorname{rod} \mathrm{A} 18$.

Evidence of fretting wear of the cladding caused by the single-layer wire spacers at midassembly was frequently noted, and the depths of the wear grooves were measured with a special gauge for over half of the rods. Some relatively severe cases of fretting wear are shown in Figure 15. In one instance the fretting resulted in complete penetration of the cladding (Figure 16).

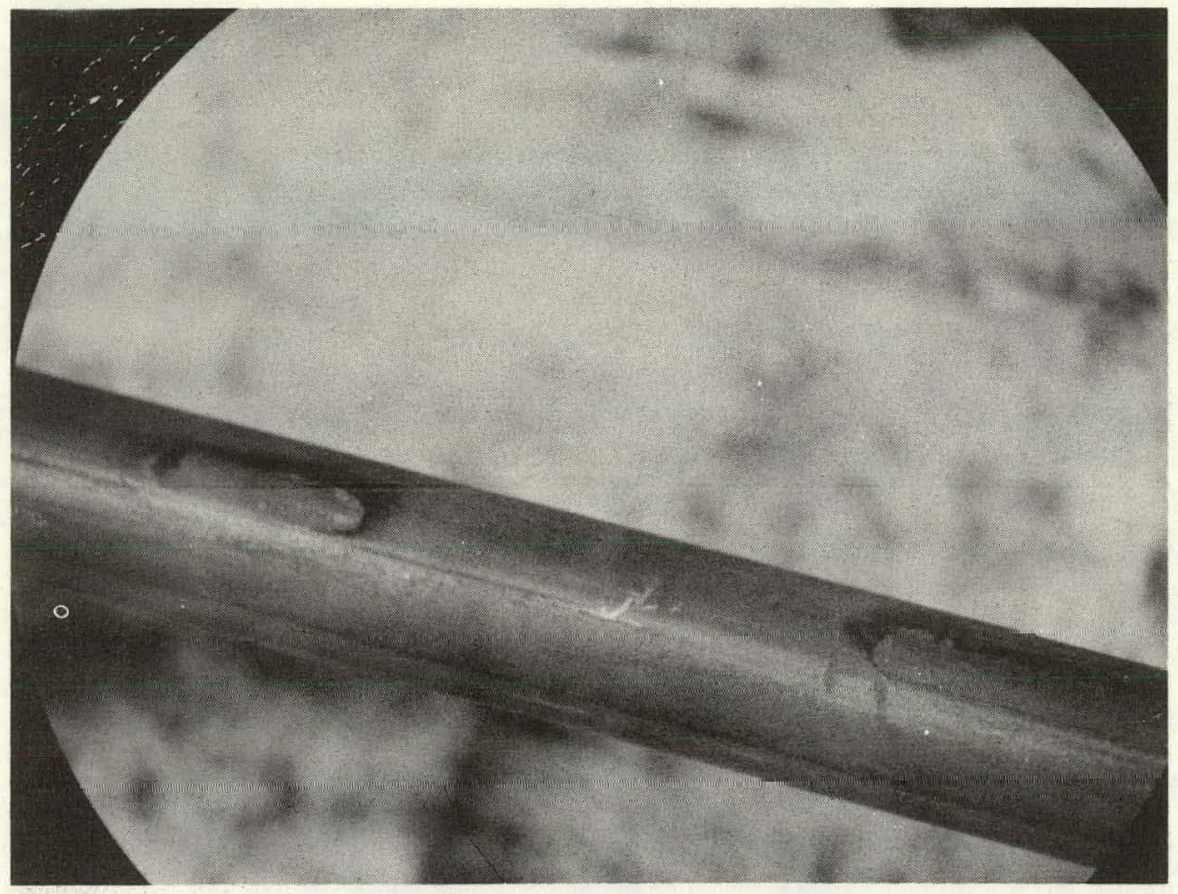

Figure 14. Irregular Patterns on Surface of Rod 14J-12 (SA-1, Rod A18)

The corner rods of 13 assemblies were fastened to the top and bottom tie plates with jam nuts that were tack welded. Removal of these rods was not attempted. 


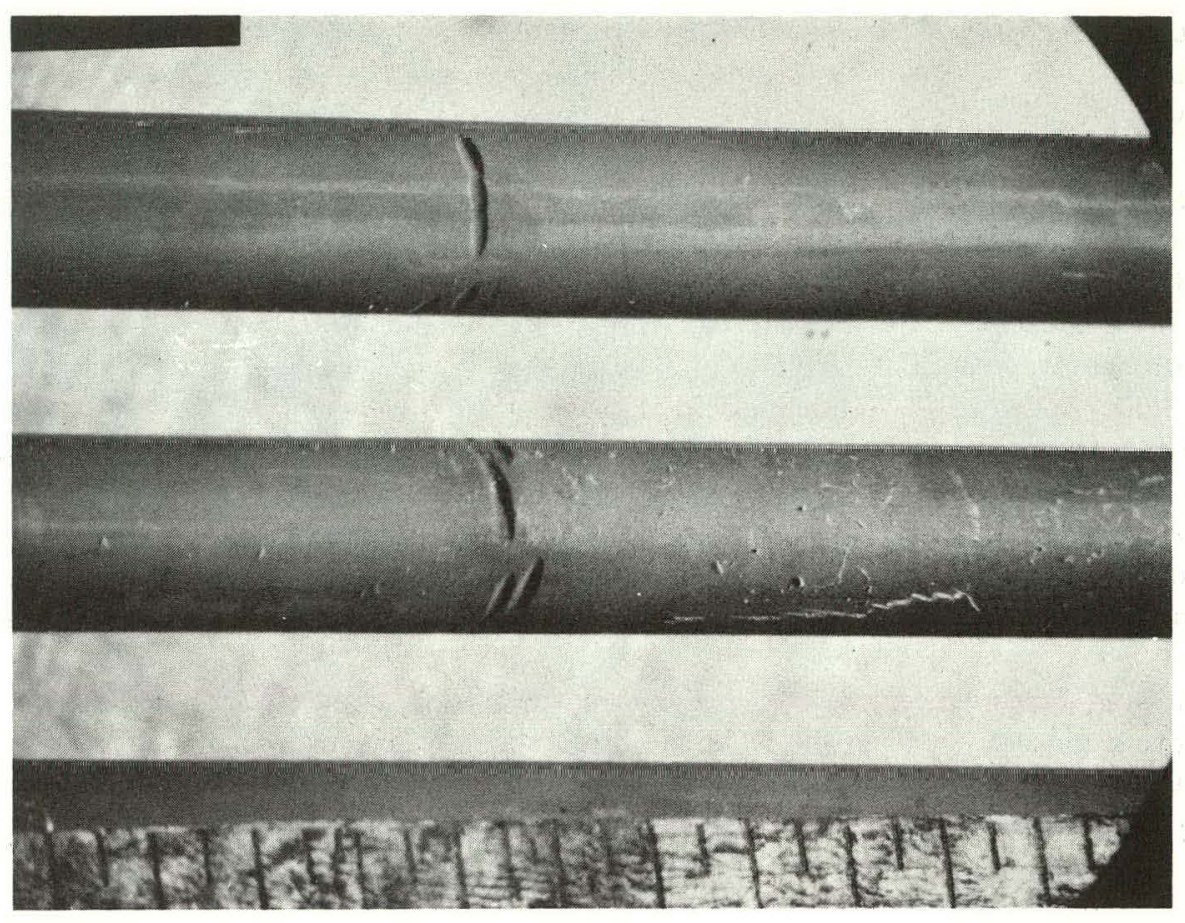

Figure 15. Severe Fretting Wear at Single-Layer Wire Spacer Contacts

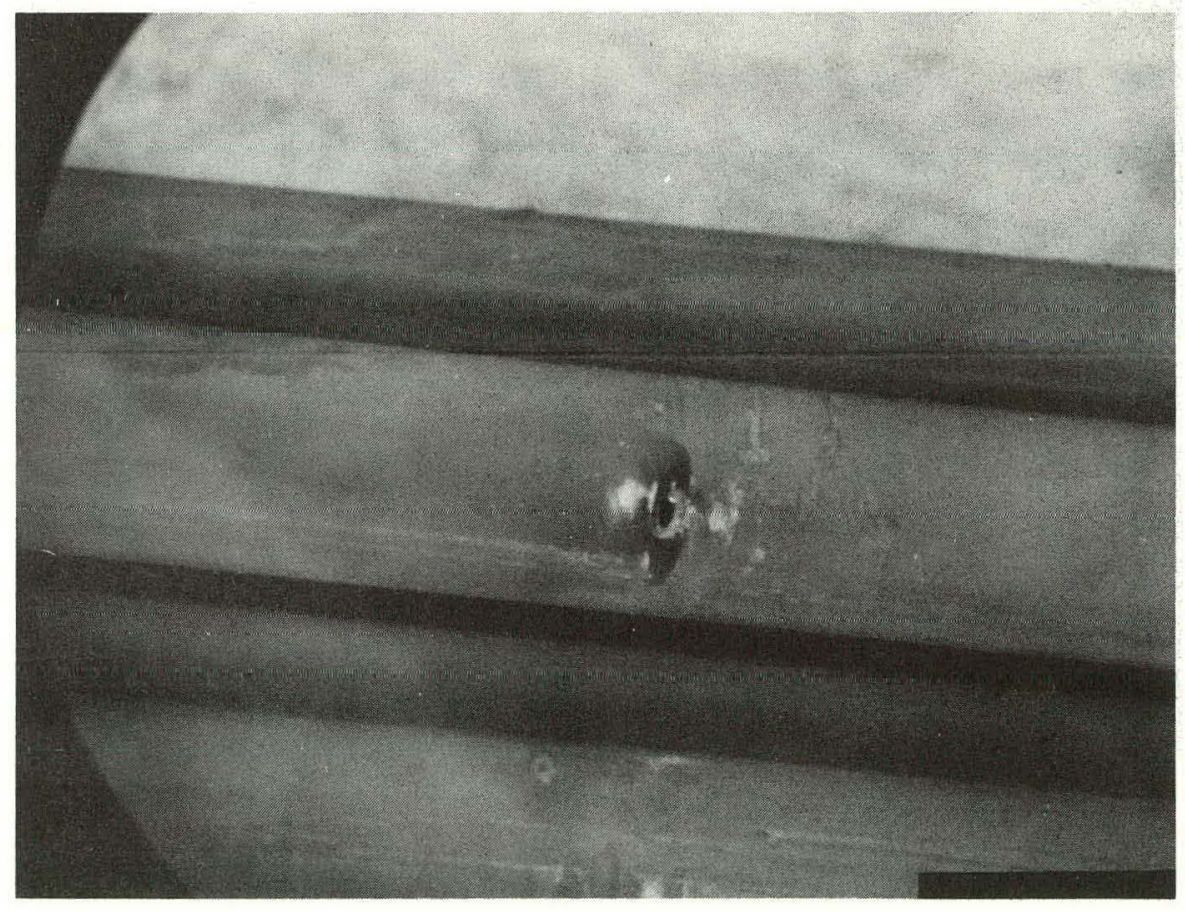

Figure 16. Fretting Wear Defect in Rod 14J-5 
Another fuel rod (Zircaloy-4-clad rod 25J-15) contained a $0.076 \mathrm{~cm}(0.030 \mathrm{in}$.) diameter hole slightly below the middle spacer location: It was concluded that this defect was an anomaly that occurred during some phase of the post-irradiation handling operations. ${ }^{2}$

Several Type $\mathrm{J}$ fuel rods were selected for more detailed examinations, the results of which are summarized in the following paragraphs. These rods were of the same design as those in SA-1, were fabricated by the same processes in the same shop and at the same time, and has similar VBWR operating histories.

Diameter measurements made with a micrometer on two Zircaloy-2-clad rods and a Zircaloy-4-clad rod whose average exposures ranged from $1.6 \times 10^{20}$ to $2.9 \times 10^{20}$ fissions $/ \mathrm{cm}^{3}$ (5700 to $10,400 \mathrm{MWd} / \mathrm{tU}$ ) showed random increases in diameter ranging from 0 to $0.0051 \mathrm{~cm}(0.002 \mathrm{in}$.). These increases may have been associated with the adherent zirconium oxide and/or crud film. A general increase in length on the order of 0.10 to $0.14 \mathrm{~cm}(0.04$ to 0.055 in.) also was observed on the same rods.

Gamma scans of four Type J rods showed peak activities 31 to $35 \mathrm{~cm}$ (12 to $14 \mathrm{in}$.) up from the bottom (short) end plug shoulder. The ratio of peak activity to rod-average activity ranged from 1.42 to 1.50 .

The corrosion film thicknesses were measured metallographically at various locations on several fuel rods, and the external film thickness measurements were converted to oxide weight gains. The oxide weight gains for the Zircaloy-2 specimens showed localized spots up to $600 \mathrm{mg} / \mathrm{dm}^{2}$, but averaged $125 \mathrm{mg} / \mathrm{dm}^{2}$ for 365 days of exposure. Motallographio oramination of cootione through come of the mettled areac neted in the vicual inspections revealed that these patterns were only shallow surface effects and slightly nonuniform corrosion of the Zircaloy. Some of the areas apart from the middle spacer locations where relatively large ultrasonic signals were obtained also were examined metallographically. It was concluded that these signals were not caused by cladding defects but, instead, probably by local variations in corrosion film thickness. ${ }^{2}$

The maximum hydrogen content of any of the Zircaloy- 2 specimens, as determined by metallographic examination and hot vacuum extraction techniques, was less than $60 \mathrm{ppm}$. Thus, the maximum increase in hydrogen content was estimated to have been about $30 \mathrm{ppm}$ during the 365 -day exposure. This amounted to an apparent maximum pickup fraction of less than $10 \%$. The metallographic examination revealed that there had been no radial or axial migration of the hydrogen.

The crud deposit, measured on metallographic specimens from one of the highest burnup rods that had operated 365 days, averaged 18 microns in thickness. Analyses of crud samples indicated that the primary constituent was $\mathrm{Fe}_{2} \mathrm{O}_{3}$.

Irradiation of the Zircaloy-2 cladding to fast fluences between $\sim 0.7 \times 10^{21}$ and $\sim 1.5 \times 10^{21} \mathrm{nvt}>1 \mathrm{MeV}$ resulted in marked increases in strength and decreases in ductility in the room temperature and $343^{\circ} \mathrm{C}\left(650^{\circ} \mathrm{F}\right)$ tensile testing of longitudinally oriented coupon specimens. The average increase in yield and ultimate strengths was $2200 \mathrm{~kg} / \mathrm{cm}^{2}(32 \mathrm{kpsi})$ and $1800 \mathrm{~kg} / \mathrm{cm}^{2}(26 \mathrm{kpsi})$ at room temperature and $2600 \mathrm{~kg} / \mathrm{cm}^{2}(37 \mathrm{kpsi})$ and $1900 \mathrm{~kg} / \mathrm{cm}^{2}$ $(27 \mathrm{kpsi})$ at $343^{\circ} \mathrm{C}$. The total elongations were decreased to values of $2 \%$ to $5 \%$ at room temperature and $1 \%$ to $2 \%$ at $343^{\circ} \mathrm{C}$. Burst test specimens tested at room temperature showed considerably greater strength and ductility than the tensile coupons. There was no well-defined effect of irradiation level on the mechanical properties over the range of exposures mentioned above.

Fission gas release percentages on four rods ranged from $0.3 \%$ to $4.8 \%$. The burnups on these rods ranged trom $2.2 \times 10^{20}$ to $2.9 \times 10^{20}$ fissions $/ \mathrm{cm}^{3}(\sim 8000$ to $10,000 \mathrm{MWd} / \mathrm{tU})$.

\section{ROD SELECTION AND ASSEMBLY PROCEDURE}

I he y8 SA-I rods were selected on the bases of the ultrảsonic ànd visual inspection results, the wear groove depth measurements, the rod average burnup as computed by physics methods, and the residual fissile content.

The ultrasonic inspection results on those rods that were chosen for SA.1 are given in Table 10. All but four of these rods gave at least one small signal, i.e., no greater than that produccd by a $0.008 \mathrm{~cm}(0.003 \mathrm{in}$.) deep notch. Fifteen rods gave signals comparable to those produced by starldard nulches belweeri $0.013 \mathrm{~cm}(0.005 \mathrm{in}$.) and $0.030 \mathrm{~cm}(0.012 \mathrm{in}$.) deep, six rods gave signals comparable to that produced by the $0.030 \mathrm{~cm}$ notch, and one rod (B92) gave an indication somewhat greater than that produced by the $0.030 \mathrm{~cm}$ notch. Most of the larger signals occurred near the middle spacer wire locations. The depths of fretting wear according to measurements made with the special gauge also are given for the SA-1 rods in -Table 10 Seyenteen of the SA. 1 rods har wear grnnves n.n1.3 rm $(0.005 \mathrm{in}$.) or more deep. The deepest grooves in any of the SA-1 rods were shown by rods A24 and A31 $10.025 \mathrm{~cm}$ or $0.010 \mathrm{in.l}$. 
Table 10

INSPECTION OF SA.1 RODS BETWIEEN VBWR AND DRESDEN OPERATION

\begin{tabular}{|c|c|c|c|c|c|c|c|c|c|c|c|}
\hline \multirow[b]{2}{*}{$\begin{array}{l}\text { SA.1 } \\
\text { Number }\end{array}$} & \multirow{2}{*}{$\begin{array}{c}\text { VBwr } \\
\text { Assembly } \\
\text { Designation }\end{array}$} & \multirow[b]{2}{*}{$\begin{array}{l}\text { Fabrication } \\
\text { Number } *\end{array}$} & \multicolumn{2}{|c|}{$\begin{array}{c}\text { Terminal VBWWR } \\
\text { Burnup, Rod-Average } \\
\end{array}$} & \multicolumn{2}{|c|}{$\begin{array}{l}\text { Estimated Local } \\
\text { Peak Heat Flux }\end{array}$} & \multirow[b]{2}{*}{$\begin{array}{c}\text { Hours at } \\
\text { Temperature } \cdots\end{array}$} & \multirow[b]{2}{*}{$\begin{array}{l}\text { Genteral } \\
\text { Condition }\end{array}$} & \multirow{2}{*}{$\begin{array}{l}\text { Maximum Depth } \\
\text { of Wear at Middle } \\
\text { Spacer Location } \\
\mathrm{cm} \text { (in.). }\end{array}$} & \multirow{2}{*}{$\begin{array}{l}\text { Ultrasonic Testing Signals } \\
\text { Distance from Short End Plug Shoulder in } \mathrm{cm} \text { (Magnitude of Signal) } \ldots \ldots *\end{array}$} & \\
\hline & & & $\begin{array}{l}\text { Fissions } / \mathrm{cm}^{3} \\
\times 10^{-20}\end{array}$ & $\mathrm{MWd} / \mathrm{tU}$ & $\frac{\text { in }}{w / \mathrm{cm}^{2}}$ & $\frac{18 W B}{B t u / h \cdot f t^{2}}$ & & & & & \\
\hline$A_{1}$ & $5 \mathrm{~J}-6$ & R2D7 & 1.58 & 5760 & 85 & $27,1,000$ & 9075 & excellent & None & $18(>8)$ & \\
\hline A2 & $1 \mathrm{~J}-2$ & R1D30 & 1.49 & 5440 & 84 & 265,000 & 9075 & excellent & None & None & \\
\hline A3 & $17 \mathrm{~J}-5$ & R5D10 & 1.49 & 5460 & 100 & 317,000 & 7168 & $\ldots$ & None & $51(<8)$ & \\
\hline A4 & $17 J .8$ & R5D13 & 1.49 & 5460 & 100 & 317,000 & 7168 & -. & $0.0025(0.001)$ & $16-1 / 2(<8), 52(<8)$ & \\
\hline A5 & $4 \mathrm{~J} \cdot 15$ & R2D8 & 1.55 & 5660 & 86 & 272,000 & 9075 & excellent & $0.0051(0.002)$ & None & $:$ \\
\hline A6 & $16 \mathrm{~J}-11$ & R5D24 & 1.67 & 6090 & 100 & 316,000 & 8041 & $\ldots$ & $0.0025(0.001)$ & $51(8)$ & . \\
\hline A7 & $16 J \cdot 2$ & R5D29 & 1.85 & 6770 & 111 & 351,000 & 8041 & -- & None & $14(<8), 51(8)$ & \\
\hline A8 & $1 \mathrm{~J}-3$ & R1D4 & 1.49 & 5440 & 84 & 265,000 & 9075 & good & None & $24(8)$ & $:$ \\
\hline A9 & $12 \mathrm{~J}-2$ & R2D80 & 2.54 & 9300 & 137 & 435,000 & 8747 & good & None & $10(>8), 28(8), 51(<8)$ & \\
\hline A10 & $8 \mathrm{~J} \cdot 9$ & R2D69 & 1.46 & 5330 & 96 & 304,000 & 7347 & excellent & $0.0051(0.002)$ & $52(<8)$ & \\
\hline A11 & $13 \mathrm{~J}-12$ & R4D5 & 2.49 & 9110 & 127 & 402,000 & 8747 & good & None & $24(8), 32(<8), 52(<8)$ & \\
\hline A12 & $8 \mathrm{~J}-2$ & R3D5 & 1.46 & 5330 & 96 & 304,000 & 7347 & good & $0.0025(0.001)$ & $12 \cdot 1 / 2(>8), 52(8)$ & \\
\hline A13 & $11 \mathrm{~J}-14$ & R2D93 & 2.59 & 9480 & 132 & 418,000 & 8747 & good & None . & $6(<8), 29(<8), 32(8), 52(<8) .57<<8)$ & \\
\hline A14 & $5 \mathrm{~J} \cdot 9$ & R2D4 & 1.75 & 6400 & 95 & 301,000 & 9075 & good & $0.010(0.004)$ & $52(<8)$ & \\
\hline A15 & $173-2$ & R5D2 & 1.49 & 5460 & 100 & 317,000 & 7168 & $\ldots$ & None & $51(>8)$ & \\
\hline A16 & $8 \mathrm{~s} \cdot 12$ & R2D76 & 1.46 & 5330 & 96 & 304,000 & 7347 & good & $0.010(0.004)$ & $14\langle<8), 51(>8)$ & \\
\hline A17 & $12 \mathrm{~J}-7$ & R2D71 & 2.29 & 8370 & 124 & 392,000 & 8747 & fair & $0.0076(0.003)$ & 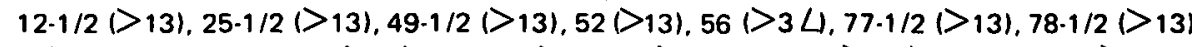 & 3): $81(>13)$ \\
\hline A18 & $14 \mathrm{~J}-12$ & R4D18 & 2.24 & 8190 & .225 & 396,000 & 8747 & fair & $0.0076(0.003)$ & $4(>13), 10(25), 40 \cdot 1 / 2|>3 \Delta, 49-1 / 2|>8), 51|131,73 \cdot-1 / 2| 3 \Delta, 76(25), 81 \mid>13)$, & $84(>13)$ \\
\hline A19 & $11 \mathrm{~J} \cdot 11$ & R1D67 & 2.33 & 8530 & 119 & 376,000 & 8747 & fair & $0.018(0.007)$ & $5(<8), 11-1 / 2 \mid>8), 19(8), 23 \mid>8), 26-1 / 2(8), 37(8), 49 \cdot 1 / 2(<30), 68-1 / 2<<8)$ & \\
\hline A20 & $9 \mathrm{9J-8}$ & R2D78 & 1.95 & 7140 & 99 & 314,000 & 9075 & good & None & $25-1 / 2(>81,28(8), 52(8)$ & \\
\hline A21 & $5 \mathrm{~J}-12$ & R2D11 & 1.75 & 6400 & 95 & 301,000 & 9075 & excellent & None & $32<<8$ & \\
\hline A22 & $17 J-3$ & R5D9 & 1.49 & 5460 & 100 & 317,000 & 7168 & ...- & None & $52(<8)$ & \\
\hline A23 & $13 \mathrm{~J} \cdot 14$ & R4D3 & 2.49 & 9110 & 127 & 402,000 & 8747 & fair & $0.0076(0.003)$ & $24(<30), 28(8), 35-1 / 2(8), 52(30), 57(8)$ & \\
\hline A24 & $14 \mathrm{~J}-9$ & R4D23 & 2.24 & 8190 & 125 & 396,000 & 8747 & fair & $0.025(0.010)$ & $19(<8), 49-1 / 2(30), 61(<8), 66(<8), 70<<8)$ & \\
\hline A25 & $8 \mathrm{8J} \cdot 10$ & R2D77 & 1.31 & 4790 & 86 & 274,000 & 7347 & excellent & $0.0025(0.001)$ & $52(8)$ & \\
\hline A26 & $13\lrcorner-8$ & R4D8 & 2.49 & 9110 & 127 & 402,000 & 8747 & good & None & $26.1 / 2(<8), 33(<8), 37(<8)$ & \\
\hline A27 & $12\lrcorner-3$ & R2D75 & 2.54 & 9300 & 137 & 435,000 & 8747 & fair & $0.013(0.005)$. & $9(8), 16 \cdot 1 / 2(>8), 18(>8), 52(<30), 59 \cdot 1 / 2<30)$ & \\
\hline A28 & $5 \mathrm{5} \cdot 2$ & R2D16 & 1.75 & 6400 & 95 & 301,000 & 9075 & fair & None & $43(<8)$ & \\
\hline A29 & 4s-12 & R2D5 & 1.55 & 5660 & 86 & 272,000 & 9075 & excellent & $0.0051(0.002)$ & None & \\
\hline A30 & $8 \mathrm{8J} \cdot 3$ & R2D73 & 1.46 & 5330 & 96 & 304,000 & 7347 & excellent & $0.0025(0.001)$ & $52(>8)$ & - \\
\hline A31 & $11 \mathrm{~J}-6$ & R1D72 & 2.33 & 8530 & 119 & 376,000 & 8747 & lair & $0.025(0.010)$ & $26.1 / 2(<8), 34(8), 391 / 2(8), 52 k 8)$ & \\
\hline A32 & 13د.9 & R4D12 & 2.49 & 9110 & 127 & 402,000 & 8747 & good & $0.0076(0.003)$ & $28(<81,51(<8), 52(<13), 57<88), 73-1 / 2<<8)$ & \\
\hline A33 & $9 \mathrm{~J}-10$ & $\mathrm{R} 3 \mathrm{D} 4$ & 1.76 & 6420 & 89 & 283,000 & 9075 & good & $0.013(0.005)$ & $12-1 / 2(<8), 43(<8), 51(30)$ & \\
\hline A34 & $9 \mathrm{~s}-12$ & R2D79 & 1.95 & 3140 & 99 & 314,000 & 9075 & excellent & None & $52(<8)$ & \\
\hline A35 & $5 J \cdot 5$ & R2D1 & 1.75 & 6400 & 95 & 301,000 & 9075 & good & $0.010(0.004)$ & $18(>8), 51(<8)$ & \\
\hline A36 & $16 J-10$ & R5D25 & 1.67 & $609 \mathrm{C}$ & 100 & 316,000 & 8041 & $\ldots$ & None & $30-1 / 2(<8), 52(<8)$ & \\
\hline A37. & 11J:5 & R1D73 & 2.59 & $948 \mathrm{C}$ & 132 & $\$ 18,000$ & 8747 & good & $0.013(0.005)$ & $1(8), 5(8), 29<88), 42(8), 51<30)$ & \\
\hline A38 ${ }^{\circ}$ & 9J-9 & R3D3 & 1.95 & 7146 & 99 & 314,000 & 9075 & fair & $0.015(0.006)$ & $14<81.51<301$ & \\
\hline A39 & $13\lrcorner \cdot 2$ & R4D11 & 2.49 & 9110 & 127 & 402,000 & 8747 & good & $0.0025(0.001)$ & $32(<8)$ & \\
\hline A40 & $9 \mathrm{~J}-2$ & R3D2 . & 1.95 & 7140 & 99 & 314,000 & 9075 & good & $0.013(0.005)$ & $52(<8)$ & \\
\hline A41 & $11 \mathrm{~J}-15$ & R6D14 & 2.59 & 9480 & 132 & 418,000 & 8747 & good & None | & $39 \cdot 1 / 2(<8), 49 \cdot 1 / 2(8)$ & \\
\hline A42 & $6 \mathrm{~J}-15$ & R2D40 & 2.17 & 7940 & 121 & 385,000 & 9075 & good & None $\mid$ & $7.1 / 2(8), 20.1 / 2(>8), 24(8), 51\left(>_{8)}\right.$ & \\
\hline A43 & $16 J \cdot 3$ & R5D28 & 1.85 & 6770 & 111 & 351,000 & 8041 & $\ldots$ & $0.0025(0.001)$ & $49-1 / 2(>8)$ & \\
\hline A44 & $5 J-14$ & R2D15 & 1.75 & 6400 & 95 & 301,000 & 9075 & good & $0.010(0.004)$ & $12-1 / 2(>8), 54-1 / 2(<8)$ & \\
\hline A45 & $5 \mathrm{~s} \cdot 15$ & R2D24 & 1.75 & 6400 & 95 & $301 ; 000$ & 9075 & fair & $0.015(0.006)$ & $52(<30)$ & \\
\hline A46 & $5\rfloor-8$ & R2D10 & 1.75 & 6400 & 95 & 301,000 & 9075 & good & None & $51<81,52(<8)$ & \\
\hline A47 & $6 \mathrm{6J} 10$ & R2D34 & 1.96 & 7150 & 109 & 346,000 & 9075 & good & $0.020(0.008)$ & $5(8), 15(8), 52(<30)$ & \\
\hline A48 & 6J.9 & R2D43 & 2.17 & 7940 & 121 & 385,000 & 9075 & good & $0.0076(0.003)$ & $4(8), 35 \cdot 1 / 2(8), 43(8), 48-1 / 2(<8), 52(>8), 64-1 / 2 \mid<8)$ & \\
\hline A49 & $6 \mathrm{~J} .5$ & R2D45 & 2.17 & 7940 & 121 & 385,000 & 9075 & good & $0.020(0.008)$ & $5(8), 12-1 / 2(8), 49-1 / 2(8)$ & \\
\hline
\end{tabular}


Table 10 (Continued)

\begin{tabular}{|c|c|c|}
\hline $\begin{array}{c}\text { SA-1 } \\
\text { Number }\end{array}$ & $\begin{array}{c}\text { VBWR } \\
\text { Assembly } \\
\text { Designation }\end{array}$ & $\begin{array}{l}\text { Fabricatio } \\
\text { Number }\end{array}$ \\
\hline B50 & $5 \mathrm{~J}-7$ & R2D25 \\
\hline B51 & $1 \mathrm{~J} \cdot 12$. & R1D3 \\
\hline B52 & 4Ј-2 & R2D23 \\
\hline 853 & 4Ј.3 & R2D22 \\
\hline 854 & $5 J \cdot 11$. & R2D14 \\
\hline 855 & $16\lrcorner .6$ & R5D 19 \\
\hline 856 & 6J.12 & R2D 32 \\
\hline 857 & 1J.14 & R1033 \\
\hline 858 & $12 \mathrm{~J} .8$ & R2D64 \\
\hline 859 & $8 \mathrm{JJ}-14$ & R2D65 \\
\hline 86ก & 13.3.15 & $R \triangle \cap ?$ \\
\hline 861 & $8 \mathrm{8J}$ & R2D70 \\
\hline 862 & $11 \mathrm{~J}-2$ & R1075 \\
\hline 863 & $16 \mathrm{~J}-5$ & R5D26 \\
\hline 864 & $4 J \cdot 5$ & R2017 \\
\hline 865 & $8 \mathrm{~J}-15$ & R2D68 \\
\hline B66 & 135.7 & R4D13 \\
\hline 867 & $14 \mathrm{~J}-2$ & R2D98 \\
\hline 868 & $12 \mathrm{~J}-6$ & R2072 \\
\hline B69 & 9J-6 & R3D8 \\
\hline 870 & $16 J-8$ & R5D15 \\
\hline B71 & $.4 \mathrm{~J}-8$ & R2D18 \\
\hline 872 & $11 \mathrm{~J}-10$ & R1068 \\
\hline 873 & $13 \mathrm{~J}-11$ & $\mathrm{R} 4 \mathrm{D7} 7$ \\
\hline 874 & 81.7 & R2D62 \\
\hline 875 & $13 \mathrm{~J}-3$ & R4D9 \\
\hline 876 & 12J-14 & R2D86 \\
\hline 877 & $16 \mathrm{~J}-9$ & R5D7 \\
\hline 878 & 4J-9 & R2D9 \\
\hline B79 & $8 \mathrm{~B}-8$ & R2D61 \\
\hline 880 & $12 \mathrm{~J} \cdot 10$ & R2DO1 \\
\hline B81 & $13 \mathrm{~J} .5$ & R4014 \\
\hline B82 & 9.1 .11 & R3OG \\
\hline 883 & $9 \mathrm{~J}-3$ & R3D10 \\
\hline 884 & $6 \mathrm{~J} \cdot 6$ & R2D 31 \\
\hline 885 & $16 \mathrm{J.7}$ & R5D18 \\
\hline 886 & $11 \mathrm{~J} \cdot 3$. & R1074 \\
\hline 887 & 9J-7 & R3D7 \\
\hline B88 & $12 \mathrm{~J} \cdot 9$ & R2D92 \\
\hline 889 & 9J-5 & R3D9 \\
\hline 890 & $11 \mathrm{~J} \cdot 0$ & ค1บ69 \\
\hline 891 & $6 \mathrm{~J}-2$ & R2D51 \\
\hline 893 & 6J.11 & R2D33 \\
\hline 893 & $18 \mathrm{~J}-12$ & R5D23 \\
\hline 894 & $16 \mathrm{~J} \cdot 14$ & R5D22 \\
\hline 895 & $16 \mathrm{~J}-15$ & R5020 \\
\hline 896 & 61.7 & R2O52 \\
\hline 897 & $6 J-3$ & R2D46 \\
\hline 898 & $6 \mathrm{JJ-8}$ & R2D38 \\
\hline
\end{tabular}
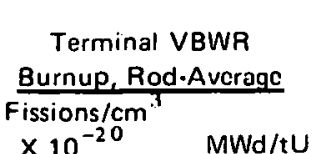

Estimated Local
Peak Heat Flux

MWd/tU W/ $/ \mathrm{cm}^{2} \quad$ Btu/hitit

5760

1.49
1.55

1.55
1.55

1.58
1.67
2.17
1.49

1.19
2.54

2.54
1.46

1.46
249
1.46

1.46
2.59

1.55
1.55

1.16

2.24
2.24
2.29

2.29
1.76
1.85
1.55
2.33

2.33

2.24

1.31
2.99

2.49
2.54
1.85

1.85
1.55
1.46

1.46
2.29

2.49
1.76
1.95
1.96

1.96
1.67

2.59

1.76

2.54
1.95
2.59

2.59
2.17

2.17
1.08

1.08
1.85

1.85
1.85
1.96

1.96
2.17
2.17

\begin{tabular}{l}
5440 \\
5660 \\
5560 \\
5760 \\
6090 \\
7940 \\
5440 \\
9300 \\
5330 \\
9110 \\
5330 \\
9480 \\
6770 \\
5660 \\
5330 \\
8200 \\
8190 \\
8370 \\
6420 \\
6770 \\
5660 \\
8530 \\
8200 \\
4790 \\
9110 \\
9300 \\
6770 \\
5660 \\
5330 \\
8370 \\
99110 \\
6420 \\
7140 \\
7150 \\
6090 \\
9480 \\
6420 \\
9300 \\
7140 \\
9480 \\
7940 \\
7150 \\
6770 \\
6770 \\
6770 \\
7150 \\
7940 \\
7940 \\
\hline
\end{tabular}

$\begin{array}{rr}85 & 271,000 \\ 84 & 265,000 \\ 86 & 272,000 \\ 86 & 272,000 \\ 85 & 271,000 \\ 100 & 316,000 \\ 121 & 385,000 \\ 84 & 265,000 \\ 137 & 435,000 \\ 96 & 304,000 \\ 127 & 103,000 \\ 96 & 304,000 \\ 132 & 418,000 \\ 111 & 351,000 \\ 86 & 272,000 \\ 96 & 304,000 \\ 114 & 362,000 \\ 125 & 396,000 \\ 124 & 392,000 \\ 89 & 283,000 \\ 111 & 351,000 \\ 86 & 272,00 \\ 119 & 376,000 \\ 114 & 362,000 \\ 86 & 274,000 \\ 127 & 402,000 \\ 137 & 435,000 \\ 111 & 351,000 \\ 86 & 27,2000 \\ 96 & 304,000 \\ 124 & 392,000 \\ 127 & 402,000 \\ 89 & 283,000 \\ 99 & 314,000 \\ 109 & 346,000 \\ 100 & 316,000 \\ 132 & 418,000 \\ 89 & 283,000 \\ 137 & 435,000 \\ 99 & 314,000 \\ 132 & 418,000 \\ 121 & 385,000 \\ 109 & 346,000 \\ 111 & 351,000 \\ 1.1 & 351,000 \\ 111 & 351,000 \\ 109 & 346,000 \\ 121 & 385,000 \\ 121 & 385,000 \\ & \\ & \end{array}$

265,000
272,000
272,000

271,000

385,000

35,000

03,000

551,000

96,000

62,000

392,000

-10
$-102,000$

435,000

14,000

385,000
346,000

351,000

351,000

385,000
385,000

\begin{tabular}{l} 
\\
Hours at \\
Eemperature $\cdots$ \\
9075 \\
9075 \\
9075 \\
9075 \\
9075 \\
8041 \\
9075 \\
9075 \\
8747 \\
7347 \\
8717 \\
7347 \\
8747 \\
8041 \\
9075 \\
7347 \\
8747 \\
8747 \\
8747 \\
9075 \\
8041 \\
9075 \\
8747 \\
8747 \\
7347 \\
8747 \\
8747 \\
8041 \\
9075 \\
7347 \\
8747 \\
8747 \\
3075 \\
9075 \\
9075 \\
8041 \\
8747 \\
9075 \\
8747 \\
9075 \\
8747 \\
9075 \\
9075 \\
8041 \\
8041 \\
8041 \\
9075 \\
9075 \\
9075 \\
\\
\hline
\end{tabular}

excellent None

None

excellent None

good $0.0076(0.003)$

fair $\quad 0.013(0.005)$

good
excellent $\quad 0.0076(0.003$

fair

None

good

Maximum Depth

Spacer Location

None
None

$0.0051(0.002)$

None
$0.0025(0.001)$

$0.0076(0.003)$

$0.0025(0.001)$

$0.0076(0.003)$

None

$0.010(0.004)$

$0.0076(0.003)$

$0.015(0.006)$

$0.013(0.005)$

$0.013(0.006)$

0.002510 .001

$0.0025(0.001)$

0.002510 .0011

$0.010(0.004)$
$0.010(0.004)$

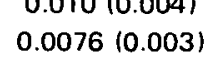

$0.013(0.005)$

$0.0076(0.003)$

$0.0051(0.002)$

None
$0.0076(0.003)$

$0.0025(0.001)$

0.007610 .0031

$0.0025(0.001)$
$0.0025(0.001)$

$0.0051(0.002)$

$0.0076(0.003)$
$0.0076(0.003)$

$(5,1<8,51<810$

$51<8)$

$25.1 / 2(8), 28(>8), 52(8)$

$5(8), 7-1 / 2(>8), 15<81,19(>8), 51(30)$

$18(8), 47(8), 57<8$

$20(16), 49-1 / 2(8)$

18 (8). $2 y|8|$ i b. (3)

$14<81.24(8) .35-1 / 2<<8), 39-1 / 2<88) .45-1 / 2(8), 52(8)$

$25-1 / 2(>8), 33(>8), 52(>8)$

$52(8)$

$4\langle 8), 18(8), 19(8), 25-1 / 2(>8), 39-1 / 2(8), 42\langle<8), 51(>8)$

$21-1 / 2(8), 28\langle<8), 52 \mid>$

$51(>8)$

$11-1 / 2(>8), 52(8)$
$52(8), 65(<.8)$

$24(8), 25-1 / 2(8), 30 \cdot 1 / 2<8), 51 \mid>8$

$38(<8), 51<30), 82-1 / 2(8)$

$33(>8), 35-1 / 2(8), 40-1 / 2(8), 49-1 / 2(<8), 52(<8), 58-1 / 2(8), 63-1 / 2<<), 75(<8), 81<8)$ $19(<8), 23(8), 30-1 / 2(8), 44-1 / 2(8), 51<8)$

$49-1 / 2<<81,52 \cdot 18$

$(51)$

$4(8), 16-1 / 2(8), 18<8), 20(8), 25-1 / 2<301,28(8), 51<8), 37(8)$

28 (8)

$12-1 / 2(8), 23(<8), 25 \cdot 1 / 2(8), 44 \cdot 1 / 2<8), 49-1 / 2(>8)$

$15(<8), 21 \cdot 1 / 2(>8), 24(>8), 26-1 / 2(>8), 30-1 / 2<30), 32(<8), 51<8)$

$12.1 / 2(8), 51(8), 61<8)$

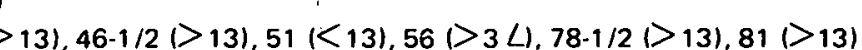
$51<<81,26.1 / 2<81<8$

$7-1 / 2(<8), 11-1 / 2(8), 15(8), 18<88), 21-1 / 2(<8), 30-1 / 2(8), 49-1 / 2(<30), 80(8)$

$52(>8)$

$5<(<8) 39.1 / 2<81,51<301$

$43(<8), 51<30), 70(8)$ 


\section{GEAP-10355}

Table 10 (Continued)

NOTES:

* Rod is designated by assembly number (e.g., $5 \mathrm{~J}$ ) followed by position number as indicated below:

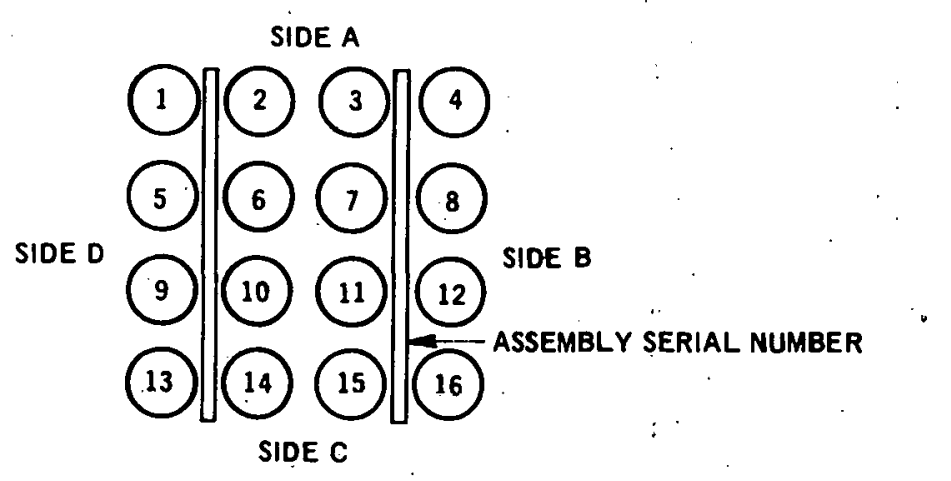

* Number immediately following the "R" indicates the lot of tubing from which the rod was fabricated, i.e., CA-1, CA-2, CA-3, CA-4, or CA-5.

Those rods fabricated from the portion of lot CA.4 tubes whose inside diameter was out of tolerance at one end were designated with numeral " 6 " e.g., rod fabrication No. R6D14 (SA-1 No. A41:).

* * Hours reactor thermal power $>5 \mathrm{MW}$

$=$ not recorded

Legend on ultrasonic testing signals:

$3=$ Signal comparable to a $0.0025-\mathrm{cm}(0.001-\mathrm{in}$.$) deep standard notch.$

$8=$ Signal comparable to a $0.0076-\mathrm{cm}(0.003-\mathrm{in}$.$) deep standard notch.$

13 = Signal comparable to a $0.013-\mathrm{cm}(0.005-\mathrm{in}$.) deep standard notch.

25 - Signal comparable to a $0.025-\mathrm{cm}(0.010-\mathrm{in}$.$) decp standard notch.$

30 = Signal comparable to a $0.030 \mathrm{-cm}(0.012 \mathrm{in}$.$) deep standard notch.$

$<=$ "Somewhat less than".

$>=$ "Somewhat greater than".

$L=$ Longitudinally oriented discontinuity. All others circumferentially oriented. 
On the bases of the ultrasonic test results, surface appearance, and wear groove depth, most of the fuel rods selected for Assembly SA-1 were judged to be in either good or excellent general condition (Table 10). Twenty SA-1 rods were given only a "fair" rating, but none of these appeared to have any possible full-wall tubing penetrations or defective end plugs or weilds.

Thirteen of the rods that were not selected for further irradiation in Assembly SA-1 gave ultrasonic signals comparable to or somewhat greater than that produced by the $0.030 \mathrm{~cm}$ standard notch. The depth of fretting wear was $0.030 \mathrm{~cm}$ in six rods and $0.038 \mathrm{~cm}(0.015 \mathrm{in}$.) in two rods according to gauge measurements. Sixteen of the rods that did not go into SA-1 were considered to be of questionable integrity on the basis of the overall examination results.

Each rod selected for Assembly SA-1 was identified by stamping a number on the longer of the two end plugs. The shank of the shorter plug was cut off with an air-driven rotary abrasive wheel so that the rod would fit in the subassembly "basket." The rod was rotated in an electrically driven Jacobs chuck while the shank was being cut. The 49 rods chosen for the subassembly designated as A-1 were loaded so that the longer plugs rested. on the bot tom grid or base; the rods for subassembly B-1 were loaded with the shorter plugs resting on the bottom grid.

The two subassemblies were loaded in a shipping cask and transported to the Dresden reactor site. In the Dresden fuel pool subassembly A.I was trañsterred from thë cask to the specially fabricated channel in such a way that the base of the subassembly rested upon the stand inside the channel. Subassembly 8-1 was then placed in the channel with its base resting upon the top of subassembly A-1. Finally, the handle hold-down assembly was secured to the top of the channel.

The arrangements of the fuel rods in the two subassemblies at the start of Dresden operation are shown in Figure 17 with the initial (cold) enrichments, and the burnups attained in the VBWR.

\section{OPERATIONAL CHARACTERISTICS OF THE ASSEMBLY}

The average exposures, U-235 contents, and fissile Pu contents calculated for the SA-1 rods at the end of VBWR operation are given in Table 11 grouped according to initial cold enrichment. The calculated reactivity ( $\left.k_{\infty}\right)$ of Assembly SA.1 in the rated temperature no void condition was 1.10. The subassembly corner angles were included in the calculations, but any effects of the spacers were not considered.

A radial power factor of 1.54 was calculated for the assembly's initial location in the Dresden core (57-14). The core contained 464 assemblies, and the maximum rated reactor thermal power was $700 \mathrm{MW}$. Hence, the maximum assembly-average power at the beginning of operation was:

$$
\frac{700}{464} \mathrm{MW} \times 1.54 \doteq 2.32 \mathrm{MW}
$$

The assembly heat transfer area was $3.11 \mathrm{~m}^{2}\left(33.5 \mathrm{ft}^{2}\right)$. Thus the assembly-average heat flux at maximum reactor power was:

$$
\frac{2.32 \times 10^{6} \mathrm{~W}}{3.11 \times 10^{4} \mathrm{~cm}^{2}}=74.6 \mathrm{~W} / \mathrm{cm}^{2}\left(237,000 \mathrm{Btu} / \mathrm{h}-\mathrm{ft}^{2}\right)
$$

The ratio of peak heat flux to average heat flux for Assembly SA-1 was determined from the following individual power peaking factors:

a. $\quad F_{\text {ax }}=$ axial factor $=1.23$ (excluding end pellet peaking).

This value was approximated from a truncated cosine skewed to such a position that its peak coincided with the center of the assembly.

b. $\quad F_{\text {e.c. }}=$ end pellet factor $=1.15$.

c. $\quad F_{1}=$ local radial factor $=1.19$.

The factor of 1.19 was the calculated relative power in the nonvoided region for the maximum power rod in a subassembly. The relative radial powers for several subassembly rod locations are shown in Figure 18 for zero voids and for $40 \%$ voids.

With the assumption that the end pellet peaking was coincident with the axial peak, the overall power peaking factor then became the product of the above three factors and equaled 1.68. 


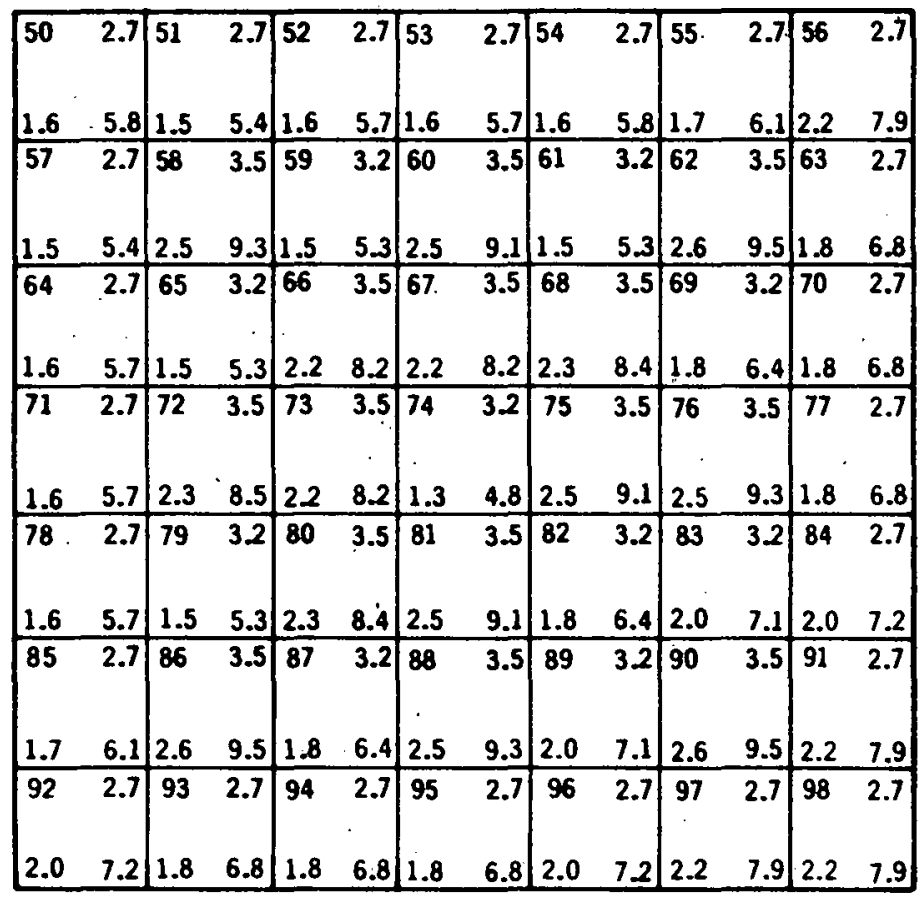

CONTROL ROD

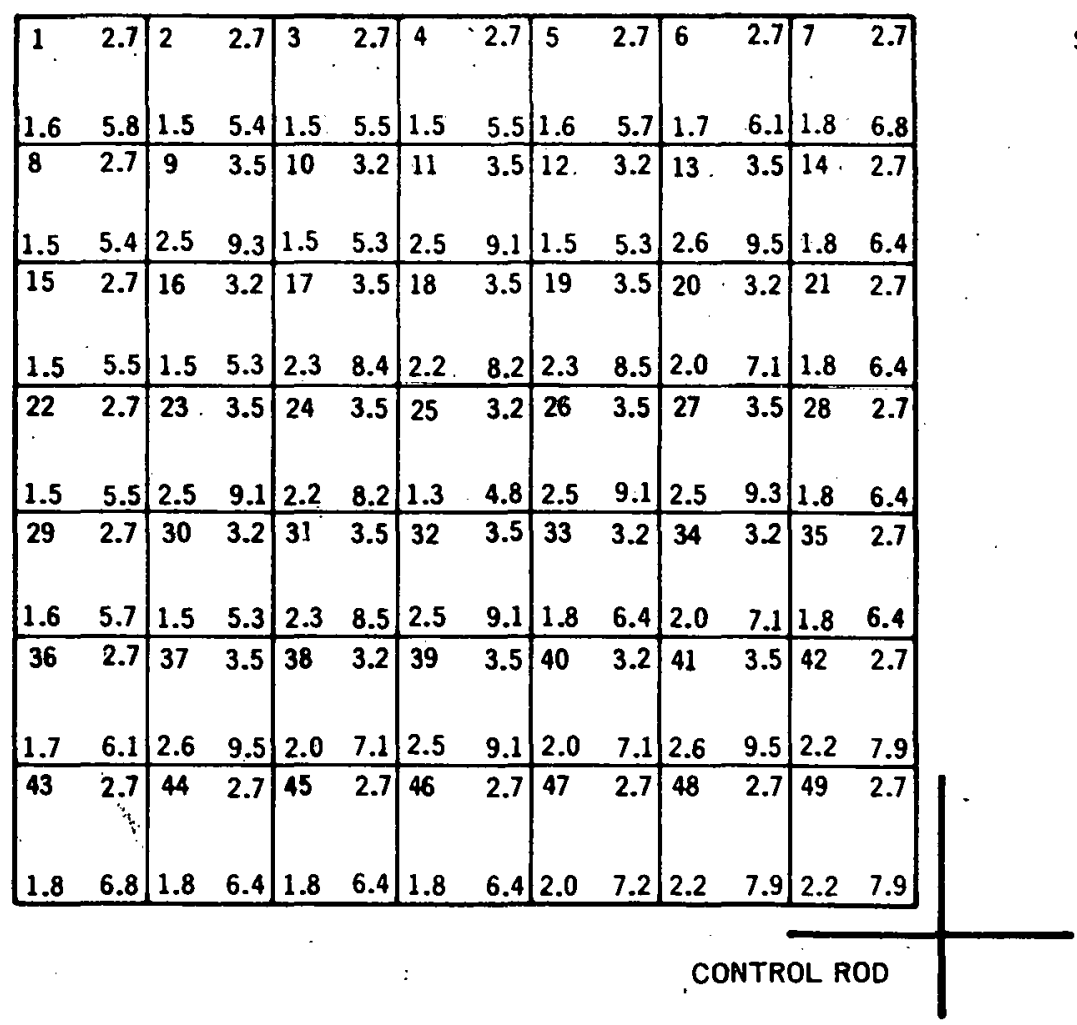

SUBASSEMBLY B-1

(TOP)

\begin{tabular}{|lc|}
\hline ROD & W/O U-235 \\
NO. & (COLD) \\
& \\
$\mathrm{flcm}^{3}$ & \\
$\times 10^{-20}$ & $\frac{\mathrm{GWd}}{\mathrm{tU}}$ \\
\hline
\end{tabular}

SUBASSEMBLY.A-1 . (BOTTOM).

Figure 17. SA-1 Rod Pattern at Beginning of Dresden Operation 

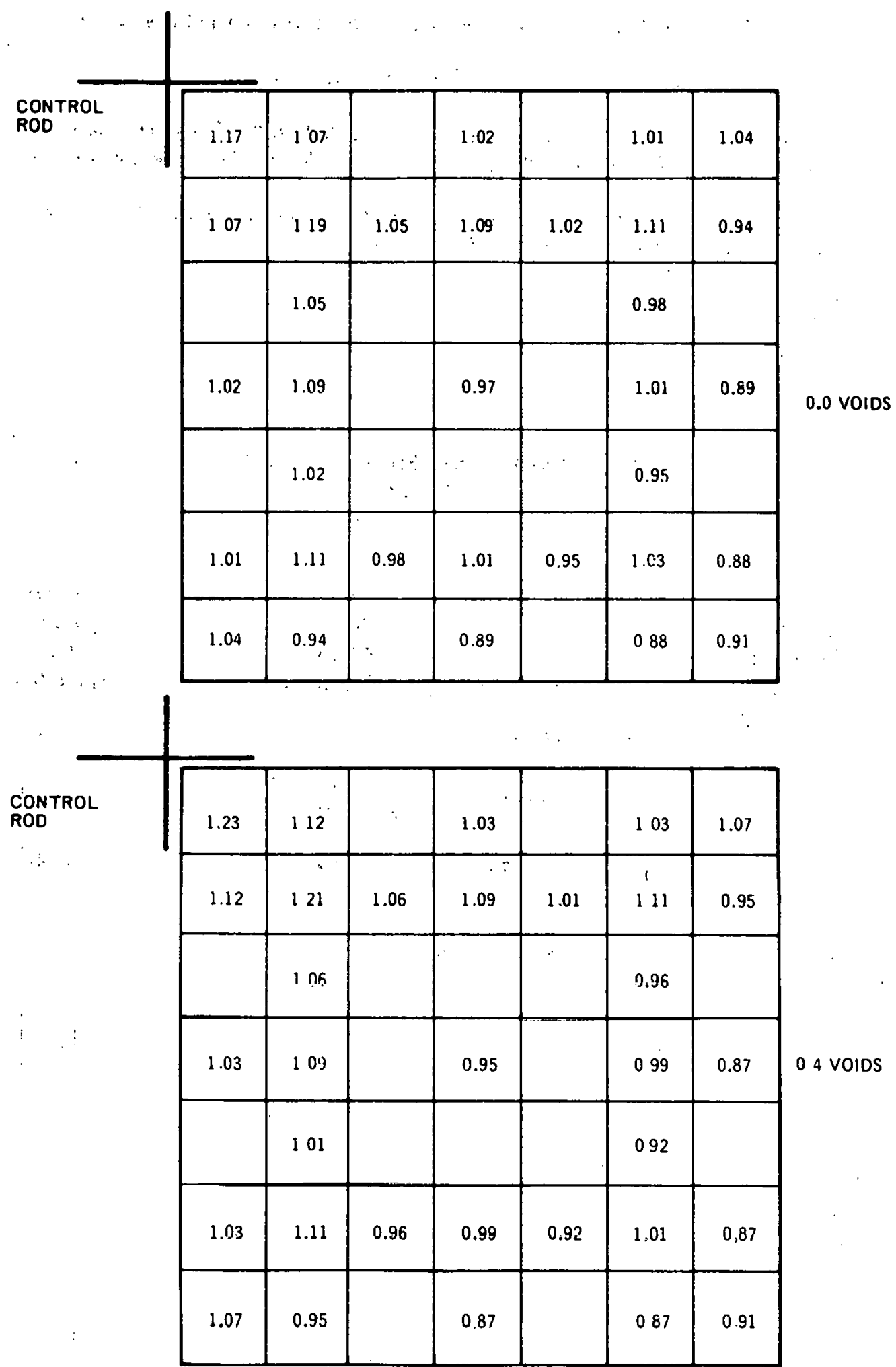

NกTF: Rlanks indicate that value for location not cpoojfically dotorminod during initial analy6is

Figure 18. Relative Radial Powers for Various Subassembly Rod Locations in Assembly SA-1 
The local peak heat flux for Assembly SA-1 at rated reactor power at the beginning of Dresden operation was:

$$
1.68 \times 74.6=125 \mathrm{~W} / \mathrm{cm}^{2} \quad\left(394,000 \mathrm{Btu} / \mathrm{h} \cdot \mathrm{ft}^{2}\right)
$$

In comparison, similar calculations indicated that $134 \mathrm{~W} / \mathrm{cm}^{2}\left(425,000 \mathrm{Btu} / \mathrm{h}-\mathrm{ft}^{2}\right)$ was the maximum peak heat flux Assembly SA-1 could have attained at rated reactor power had it been located in the peak power poșition of the core.

Shown in Figure 19 is the coolant mass flux calculated as a function of assembly power. The relationship of fuel rod centerline temperature to heat flux is shown in Figure 20.

Table 11

BURNUP AND FISSILE CONTENT OF SA-1 RODS AT END OF VBWR OPERATION

\begin{tabular}{|c|c|c|c|c|}
\hline $\begin{array}{c}\text { Number of. } \\
\text { Rods }\end{array}$ & $\begin{array}{c}\text { Cold } \\
\text { Enrichment } \\
\text { wt\% U:235 }\end{array}$ & $\begin{array}{l}\text { Average Burnup } \\
\text { Fissions } / \mathrm{cm}^{3} \text { (MWd/tu) }\end{array}$ & $\begin{array}{l}\text { Average } \\
\text { Irradiated } \\
\text { Enrichment } \\
\text { wt\% U-235 }\end{array}$ & $\begin{array}{c}\text { Average } \\
\text { Fissile } \\
\text { Pu Content } \\
\text { wt\% (Pu-239: } \\
\text { Pu-241)* }\end{array}$ \\
\hline 48 & 2.7 & $1.76 \times 10^{20}(6420)$ & 1.90 & 0.32 \\
\hline 20 & 3.2 & $1.65 \times 10^{20}(6040)$ & 2.36 & 0.31 \\
\hline 30 & 3.5 & $2.43 \times 10^{20}(8890)$ & 2.28 & 0.38 \\
\hline
\end{tabular}

*xpressed as percentage of uranium weight in unirradiated condition. 


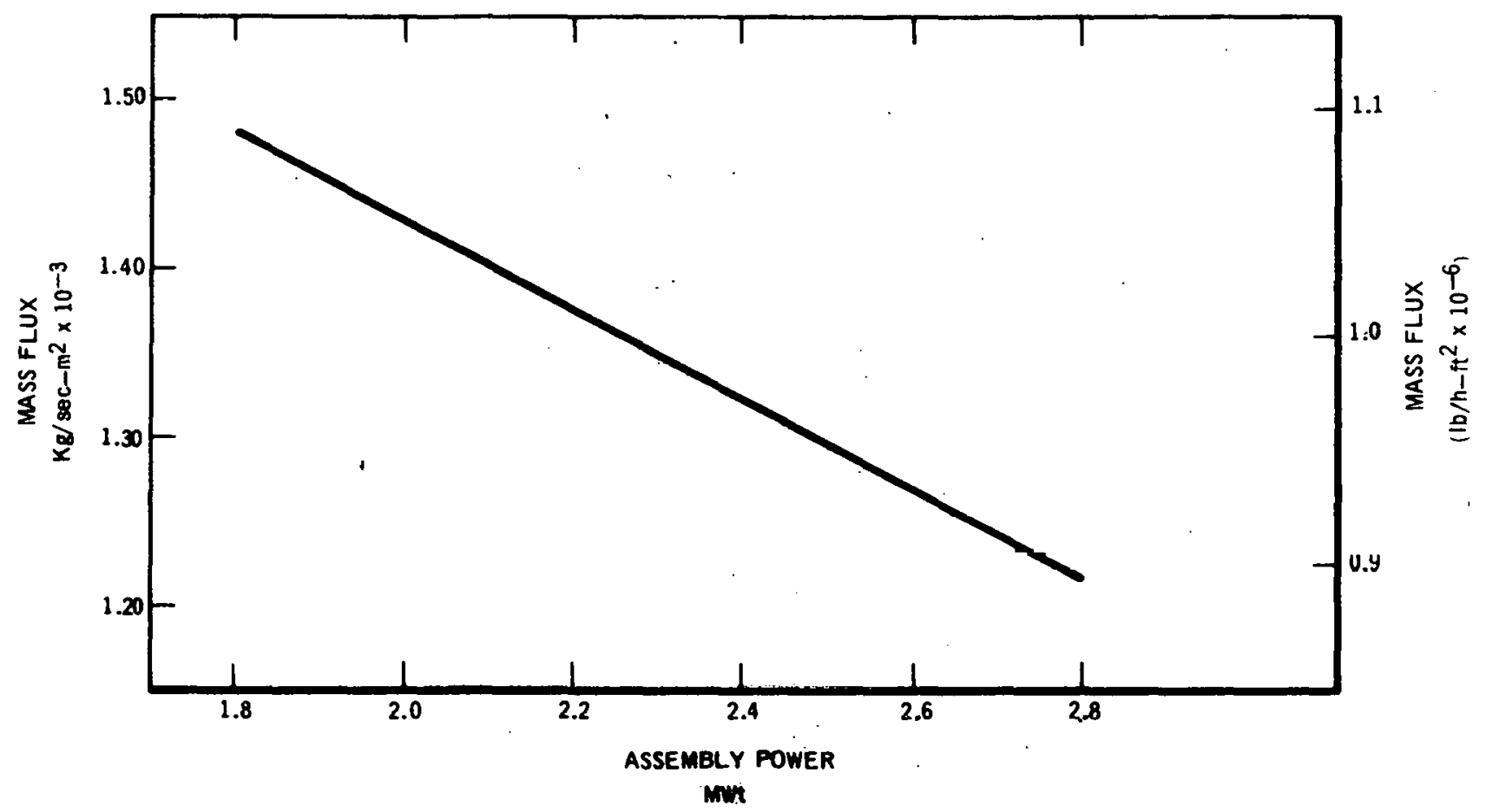

Figure 19. Coolant Mass Flix as a Function of Assembly Power

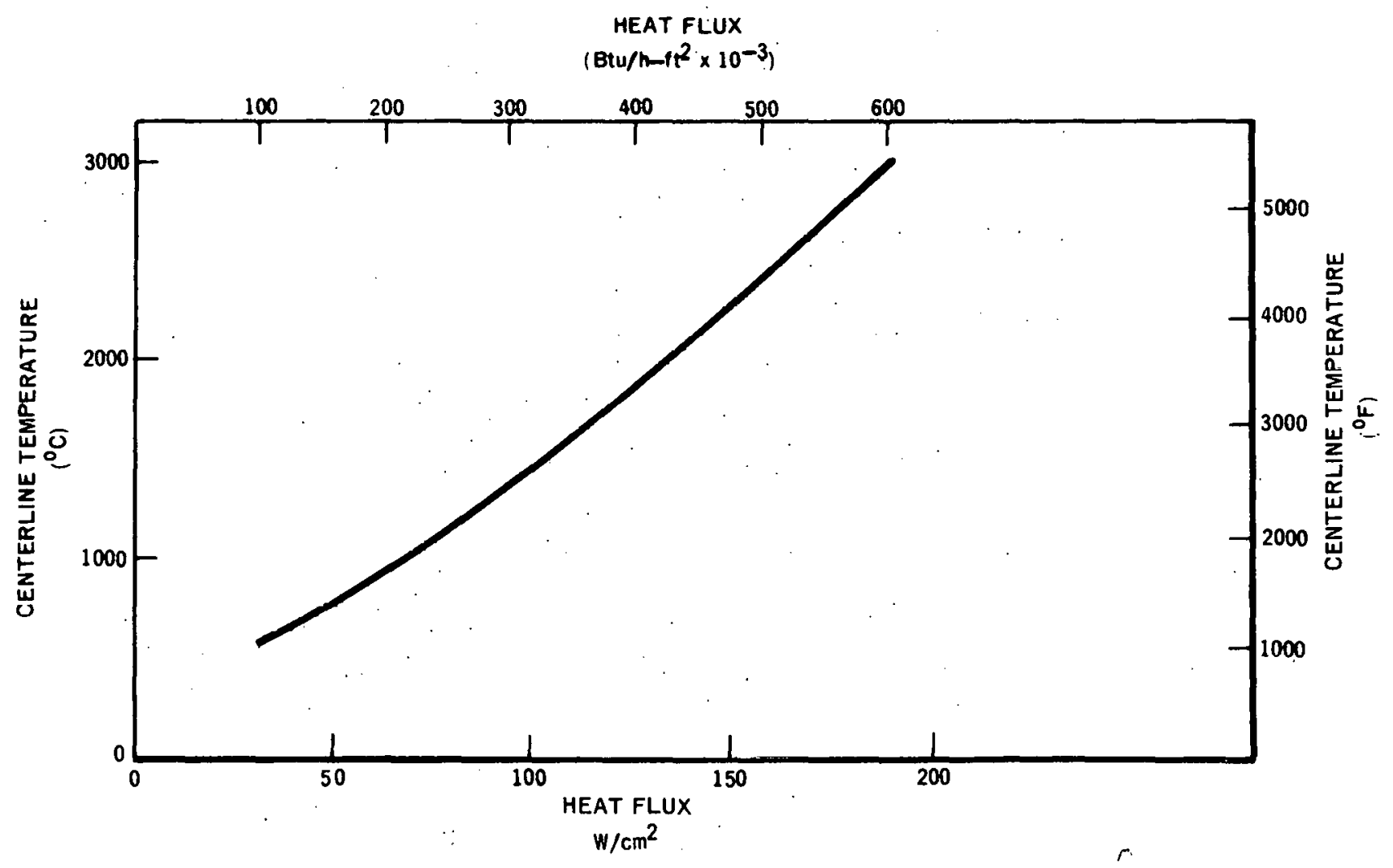

Figure 20. Fuel Centerline Temperature Versus Circumferential-Average Rod Surface Heat Flux 


\section{APPENDIX A \\ DRAWINGS*}

No.

Figure $A-1$

Figure $A-2$

Figure $A-3$

Figure A-4

Figure $A-5$

Figure $A-6$

Figure A-7

Figure A-8
Title

Fuel Bundle

Fuel Rod

End Plug

Tube

Support

Wafer

End Plug

Fuel Pellet

* All dimensions in inches. 


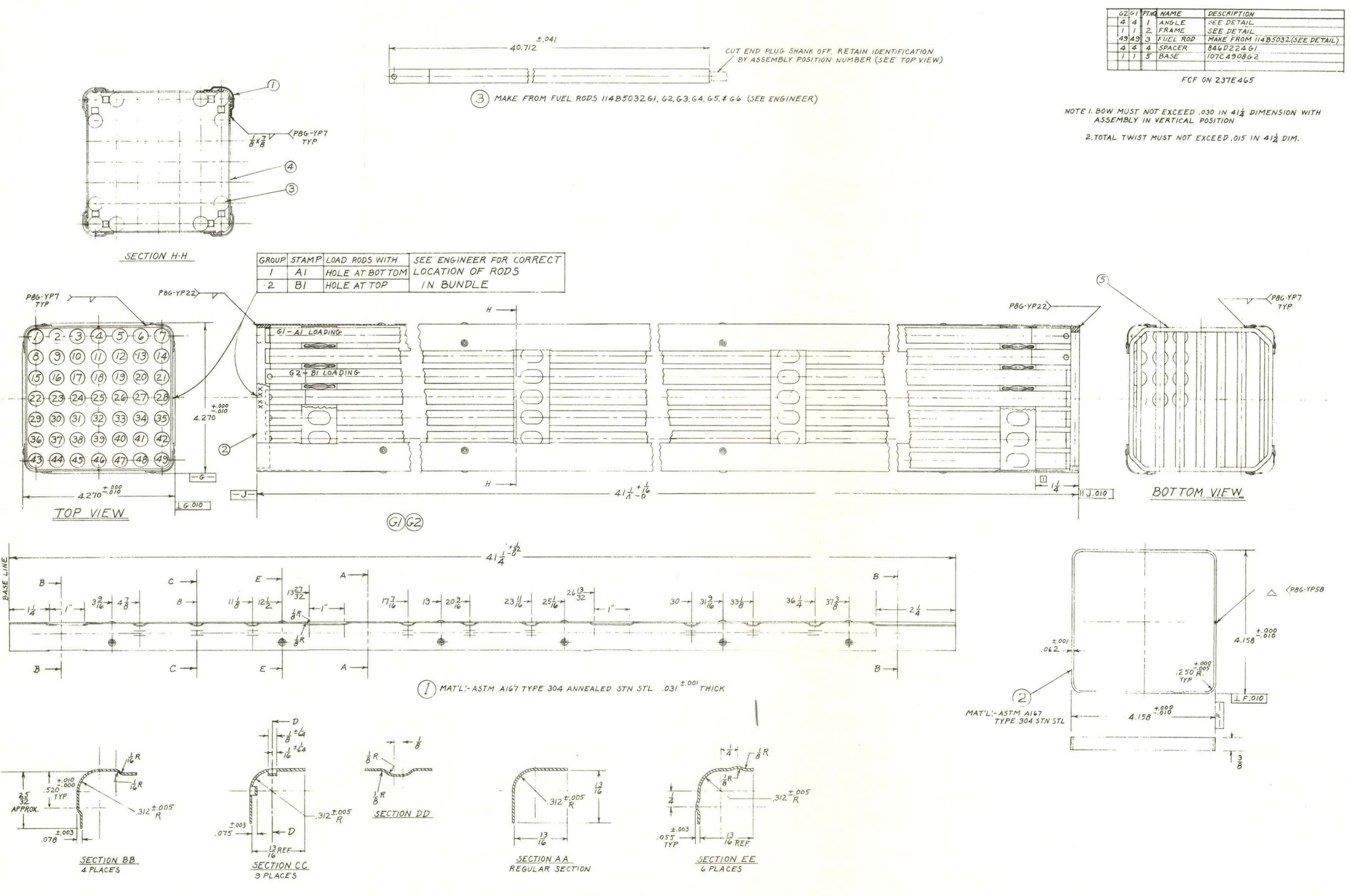




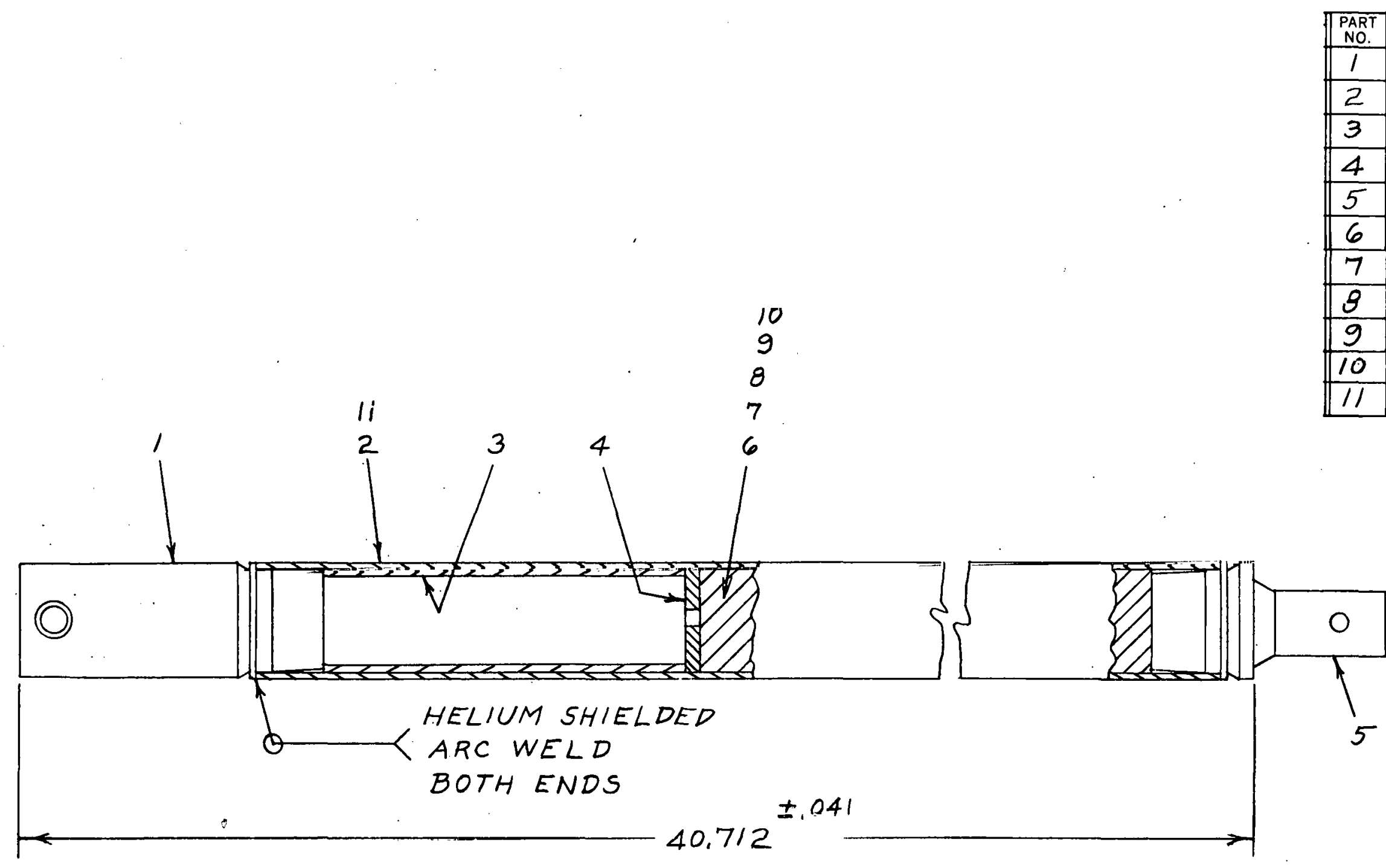

NOTE I.ASSEMBLY TO BE MADE PER PROCESS SPECIFICATION FA-19675

2. ACTIVE FUEL LENGTH $\frac{37.132}{36.867}$

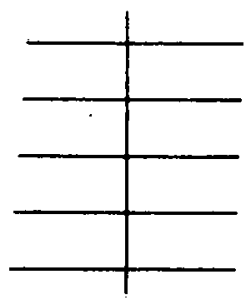




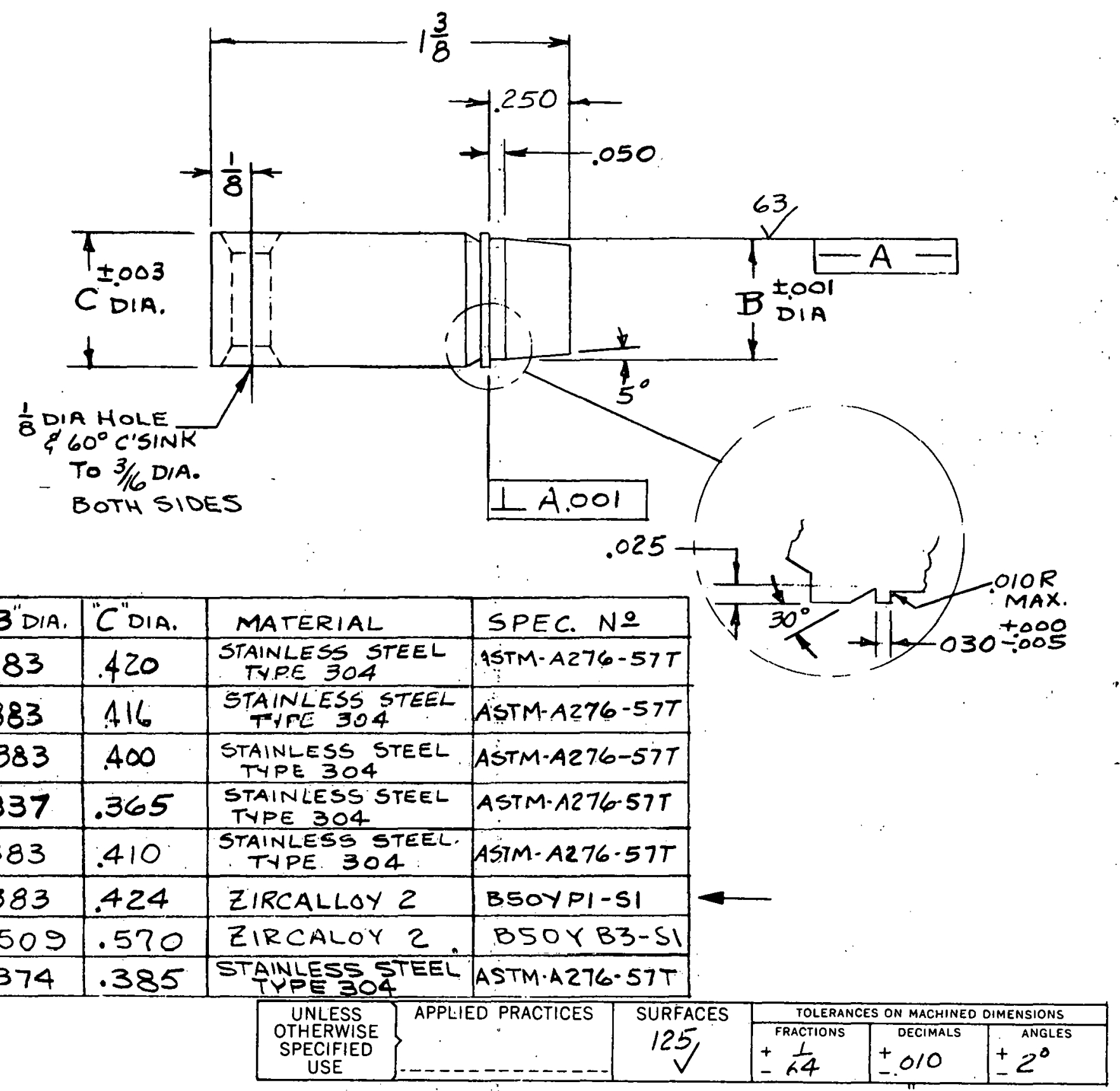

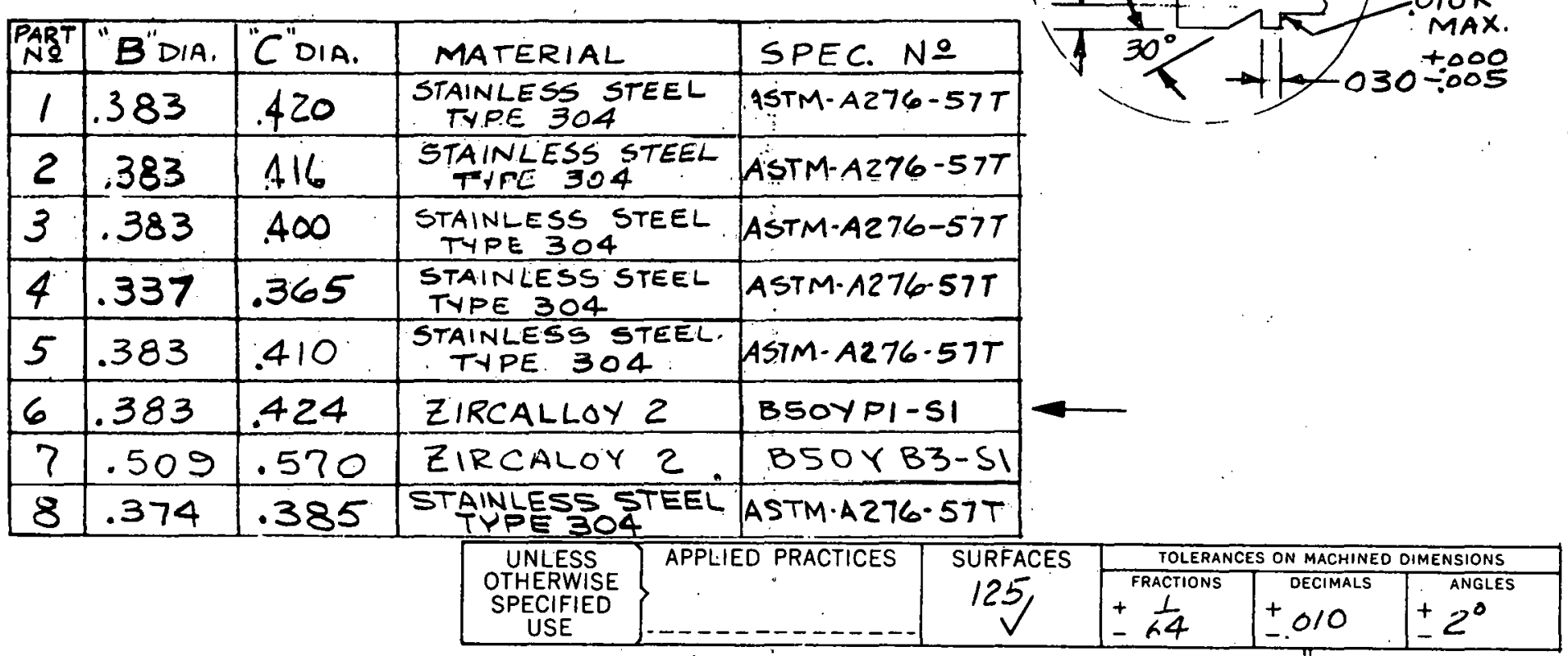

Figure A-3. End Plug 


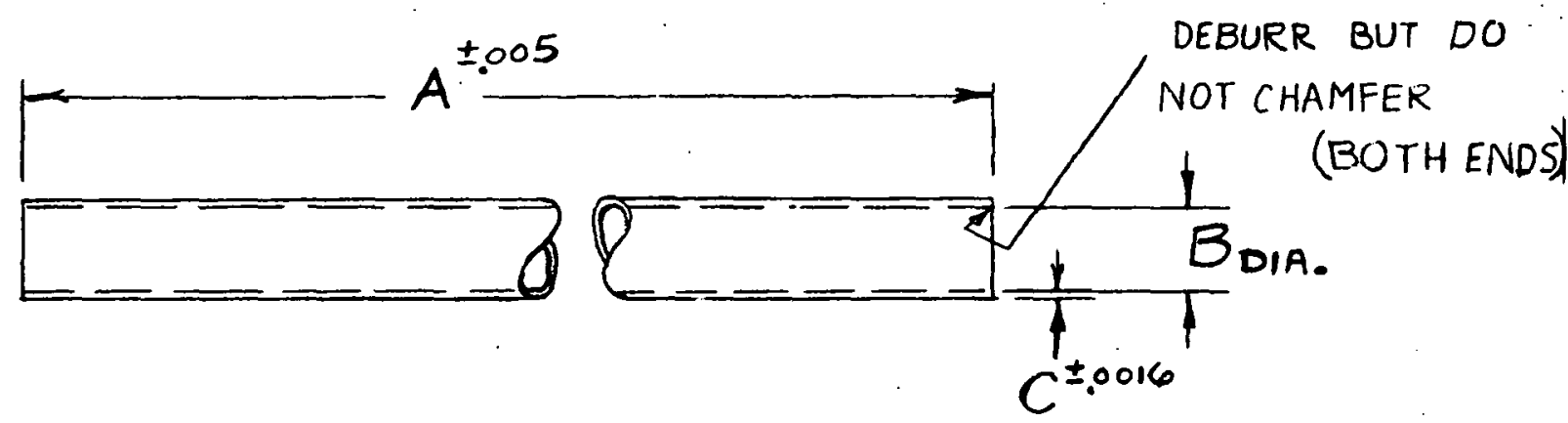

\begin{tabular}{|c|c|c|c|c|c|}
\hline \begin{tabular}{|l|} 
PART \\
$N Q$ \\
\end{tabular} & $A$ & $B$ & $C$ & MATERIAL & SPEC. NO \\
\hline 1 & 32.344 & $.380^{ \pm .0016 !}$ & .020 & $\begin{array}{l}\text { STAINLESS } \\
\text { TIPE } 304\end{array}$ & $F P-19678$ \\
\hline 2 & 38.592 & $.380^{ \pm .0016}$ & .017 & $\begin{array}{l}\text { STAINLESS ST } \\
\text { TYPE } 304\end{array}$ & $F P-19678$ \\
\hline 3 & 38.592 & $380^{ \pm .0060}$ & .010 & $\begin{array}{l}\text { STMINLEES GT } \\
\text { TYPE } 304\end{array}$ & $F P-19678$ \\
\hline 4 & 38.592 & $333+.002$ & .014 & $\begin{array}{l}\text { STAINLESS ST. } \\
\text { TYPE } 304\end{array}$ & $F P-19678$ \\
\hline 5 & 59.812 & $.333+.001$ & .014 & $\begin{array}{l}\text { STAINLESS ST } \\
\text { THPE } 304\end{array}$ & FP. 19678 \\
\hline 6 & 38.592 & $380^{ \pm 0016}$ & .015 & $\begin{array}{c}\text { STAINLESS ST. } \\
\text { TYPE } 304\end{array}$ & $F P-19678$ \\
\hline 7 & 39.462 & $380^{ \pm .0016}$ & .022 & ZIRCALOY 2 & B5OYPZ-SI \\
\hline 8 & 39.462 & $.380^{ \pm 0016}$ & .022 & ZIRCALOY 4 & $B 50 Y P Z-S 1$ \\
\hline 9 & 27.662 & $.380^{t .0016}$ & .022 & ZIRCALOY 2 & $B 50 Y P Z-S 1$ \\
\hline 10 & 10.450 & $.380^{ \pm .0000}$ & .022 & ZIRCALOY 2 & $B 50$ YPZ -51 \\
\hline 11 & 39.462 & $.509^{ \pm 001}$ & .030 & ZIRCALOY 4 & BSOY PZ- 55 \\
\hline 12 & 44.500 & .375 & .005 & $\begin{array}{l}\text { STAINLESSS STL. } \\
\text { TYPE } 3{ }^{\circ} 4\end{array}$ & B50Y PG-51-C \\
\hline
\end{tabular}

Figure A-4. Tube 


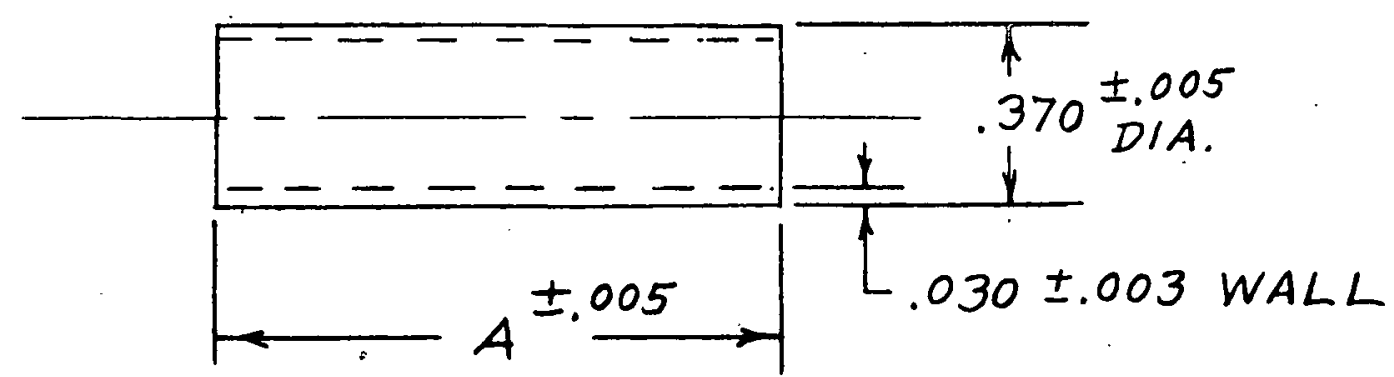

$\longrightarrow$\begin{tabular}{|c|c|l|}
\hline PT. NO. & $A$ & MATERIAL \\
\hline 1 & $1.000^{ \pm .005}$ & STN STL \\
\hline 2 & $1.900^{ \pm 005}$ & TYPE 304 \\
\hline 3 & $1.740^{ \pm .010}$ & \\
\hline
\end{tabular}

Figure A-5. Support

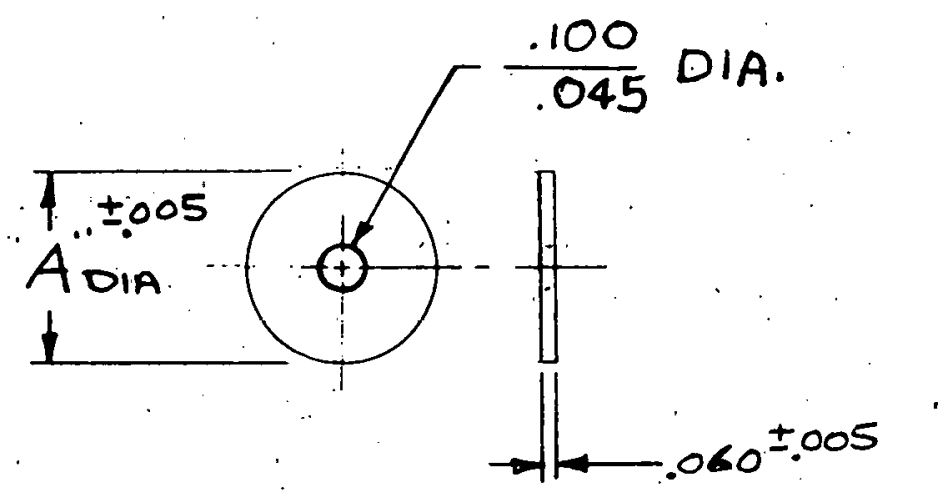

\begin{tabular}{|c|l|l|l|}
\hline P.NO & "A" DIA. & MATERIAL & SPEC. NO \\
\hline 1 & .370 & STAINLESS STEEL & ASTM-A267-57T \\
\hline 2 & .320 & TYPE 304 & STINLESS STEEL \\
TYPE 304 & ASTM-A267-57T \\
\hline 3 & .370 & ZIRCALOY 2 & BSOYPI-S1 \\
\hline
\end{tabular}

Figure A-6. Wafer 
GEAP.10355

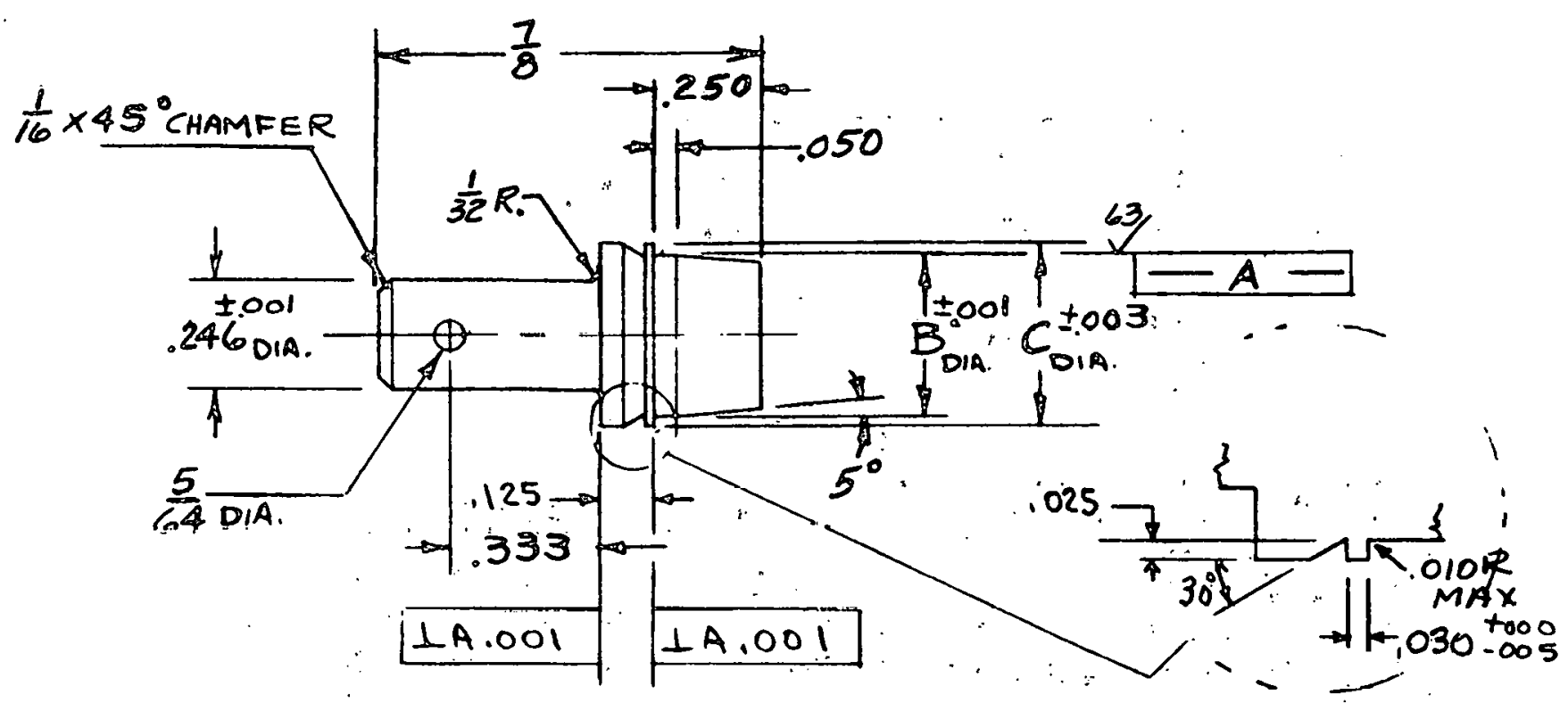

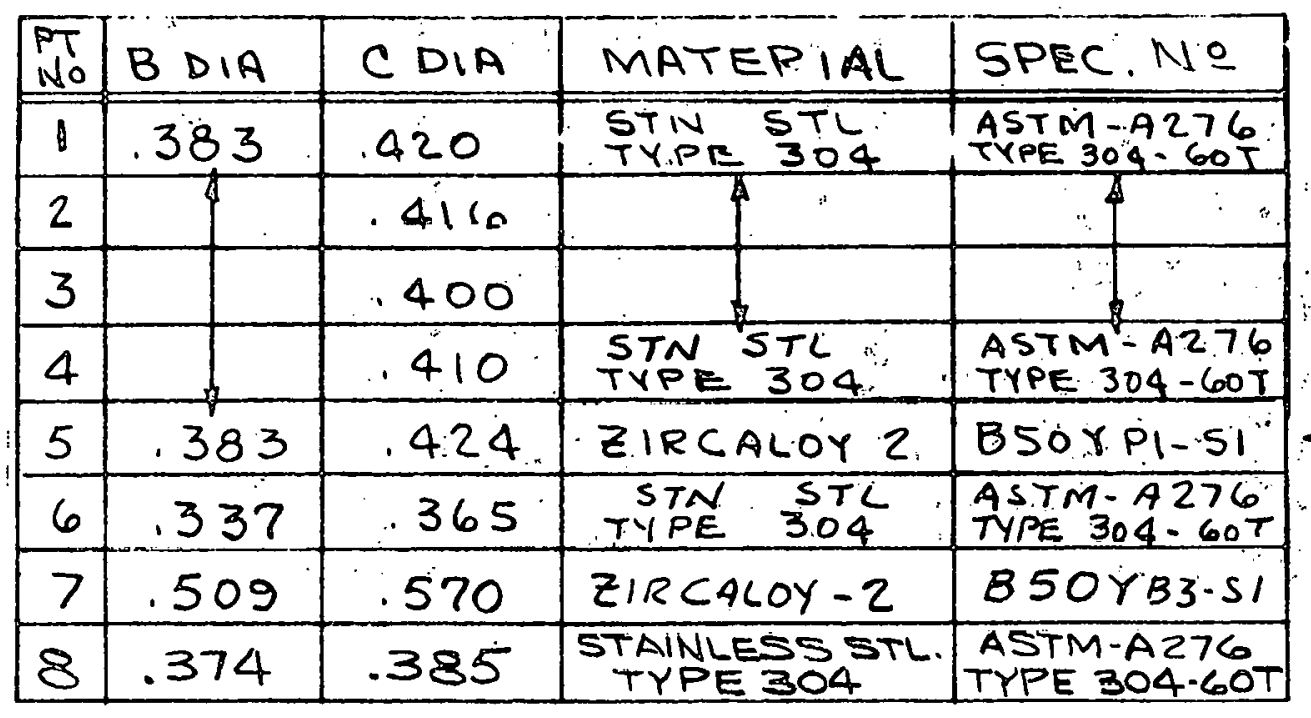

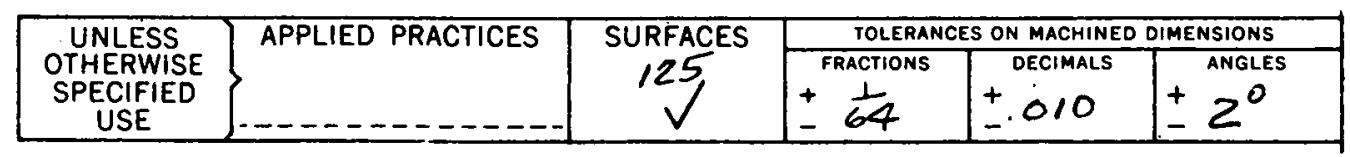

Figure A-7. End Plug

47. 


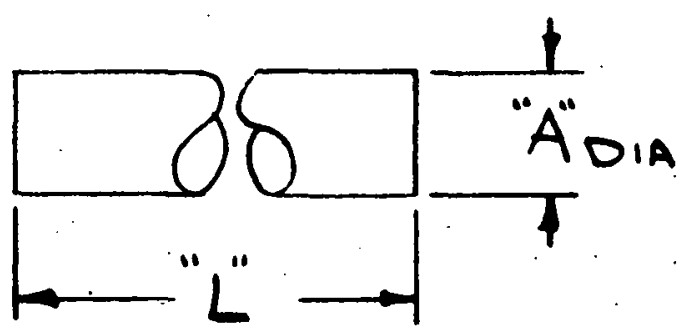

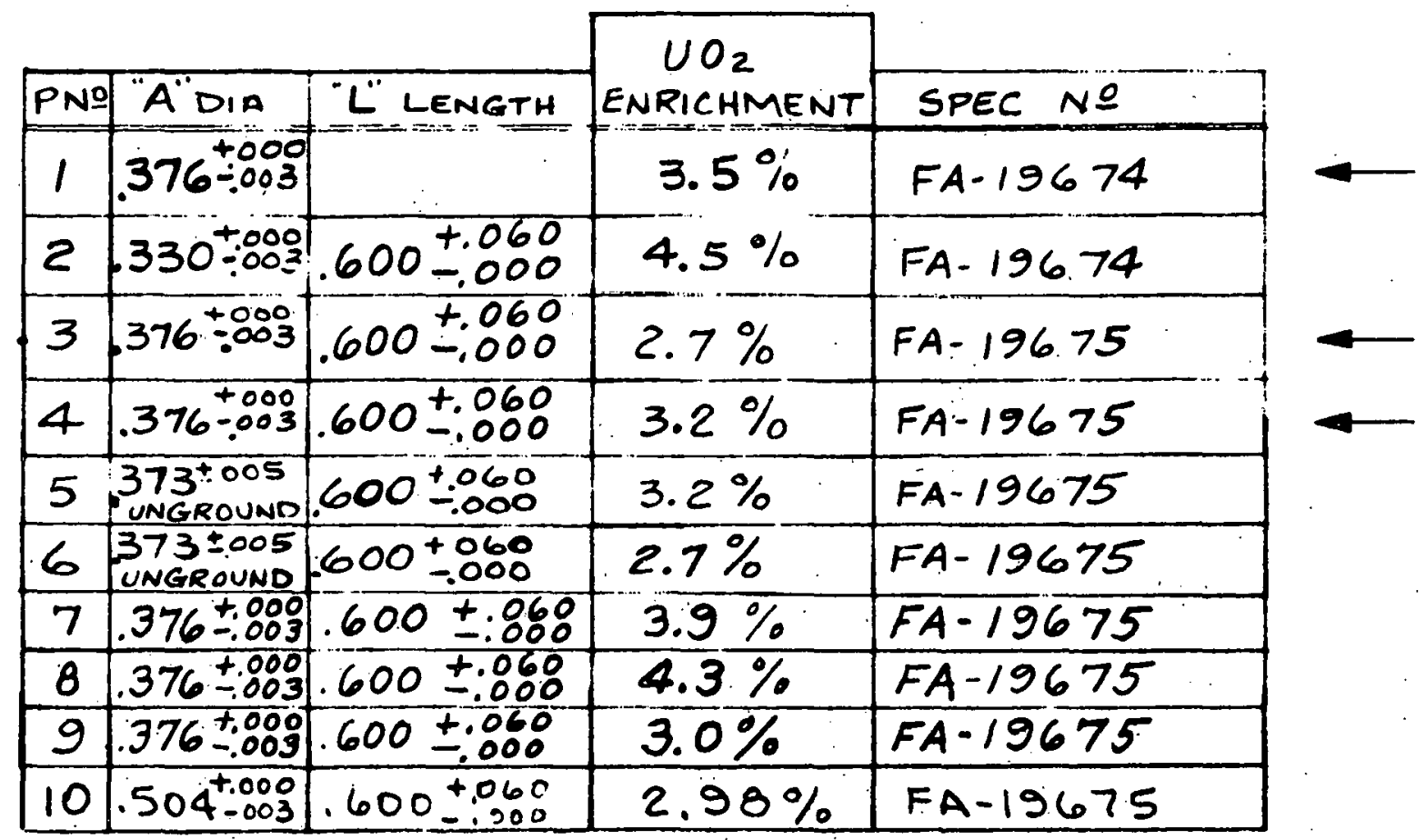




\section{APPENDIX B}

Inside Diameter and Wall Thickness Measurements

On Type J Tubing

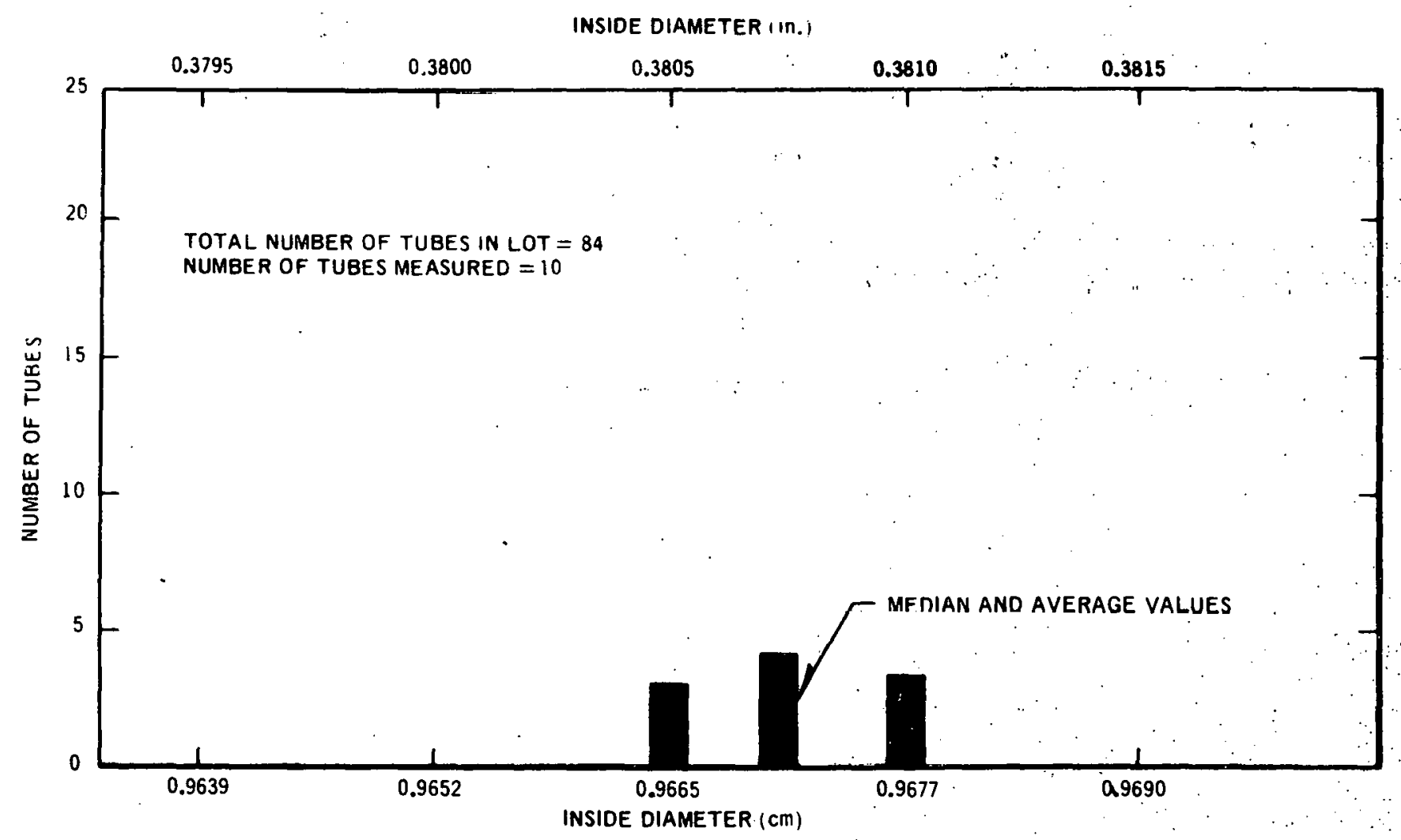

Figure B-1. Inside Diameter Measurements on Sample Tubes From Lot CA-1

-49 . 


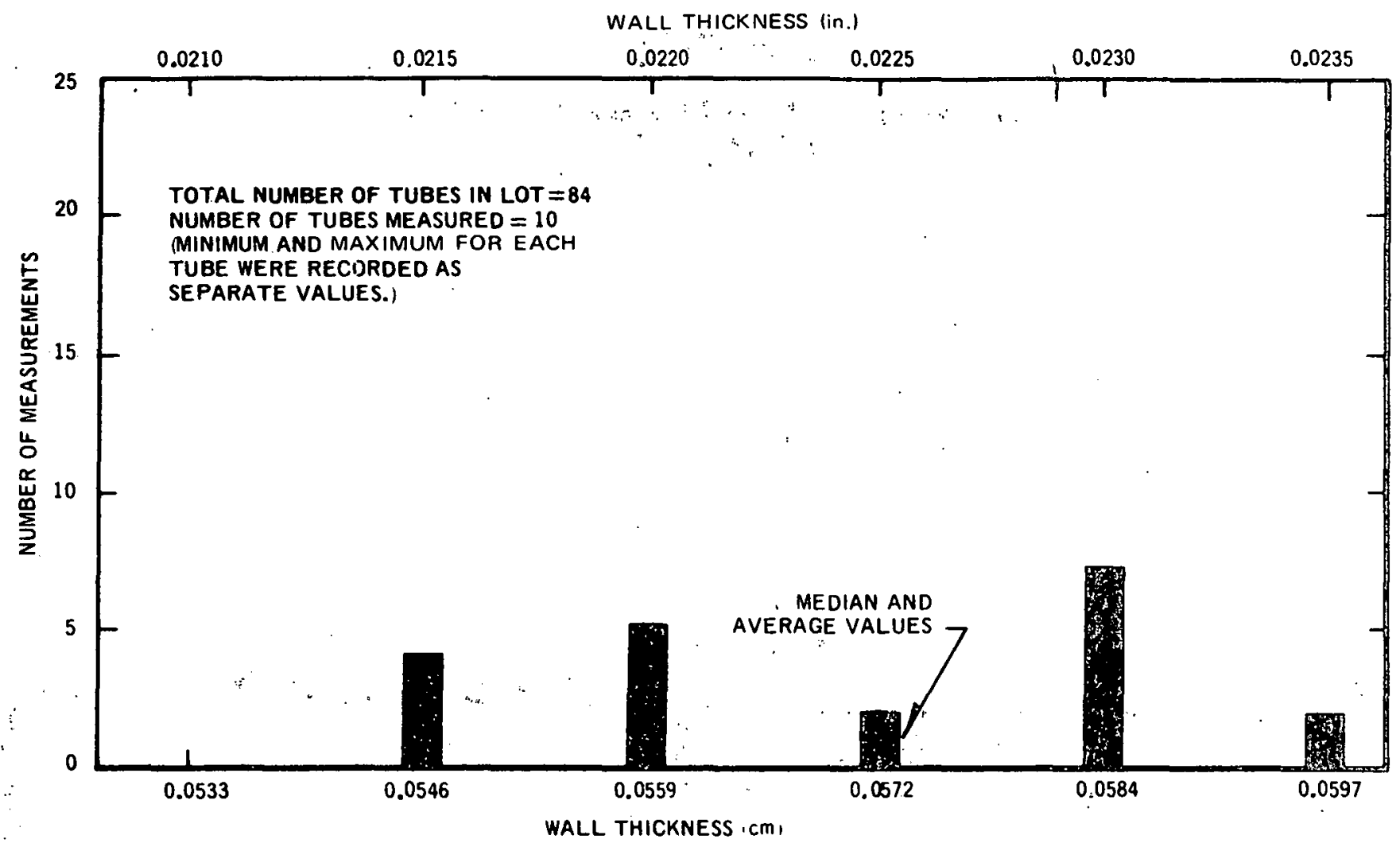

Figure B-2. Wall Thickness Measurements on Sample Tubes From Lot CA.1 MAXIMUM - MINIMUM WALL THICKNESS (in.)

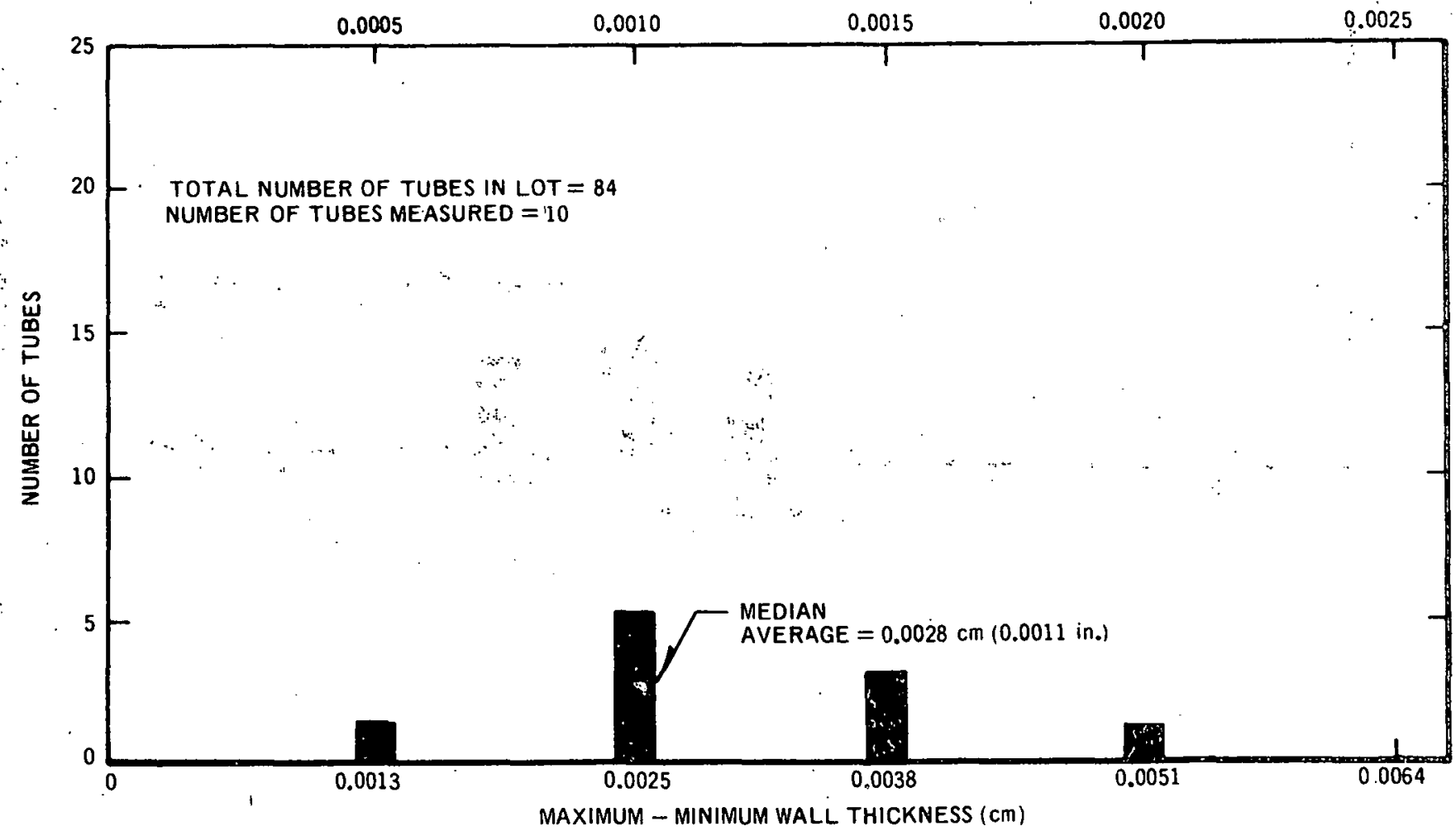

Figure B-3. Difference in Maximum and Minimum Wall Thickness Measurements ọn Individual Sample Tubes From Lot CA-1. 
INSIDE DIAMETER (In.)

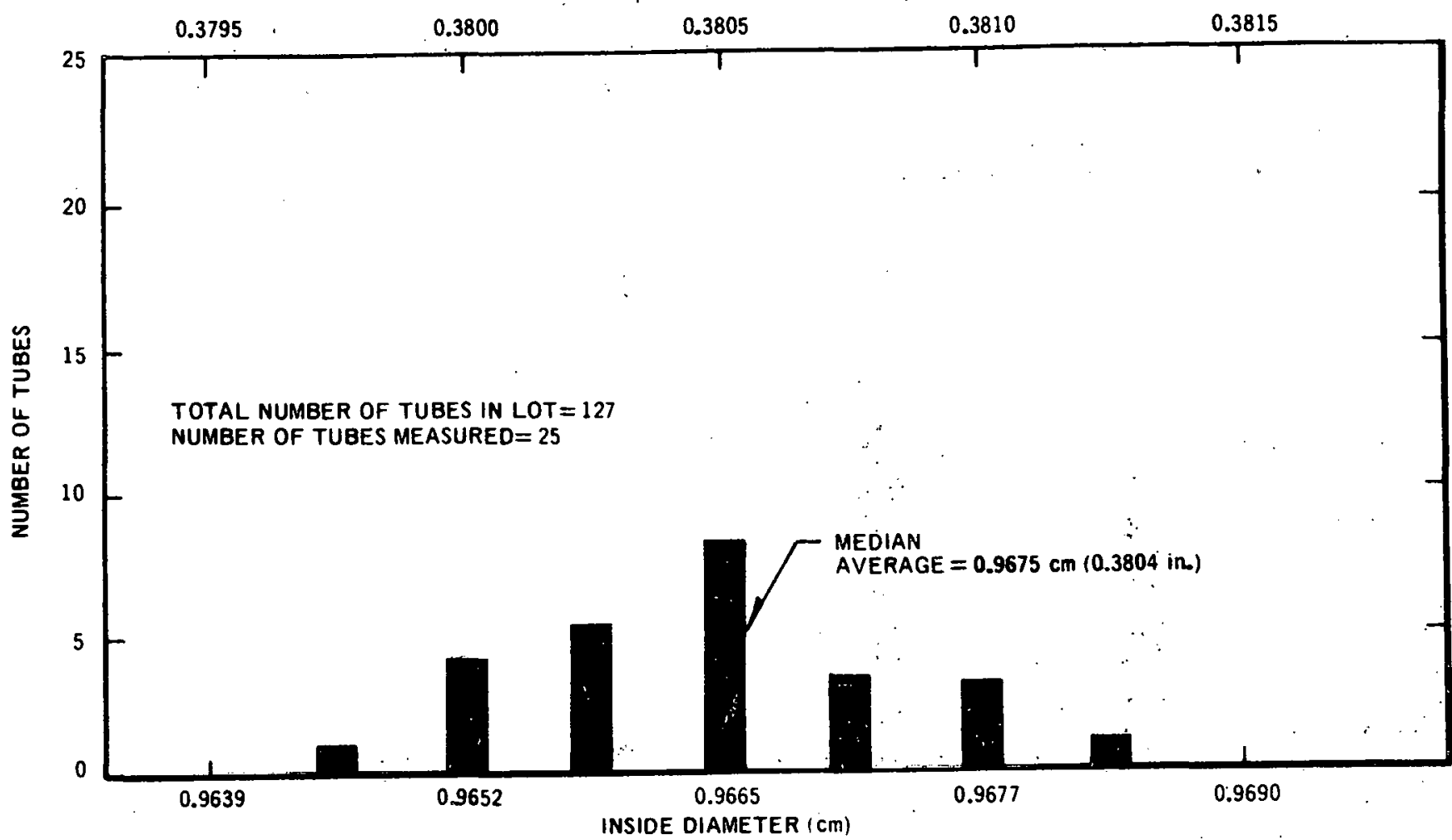

Figure B-4. Inside Diameter Measurements on Sample Tubes From Lot CA-2

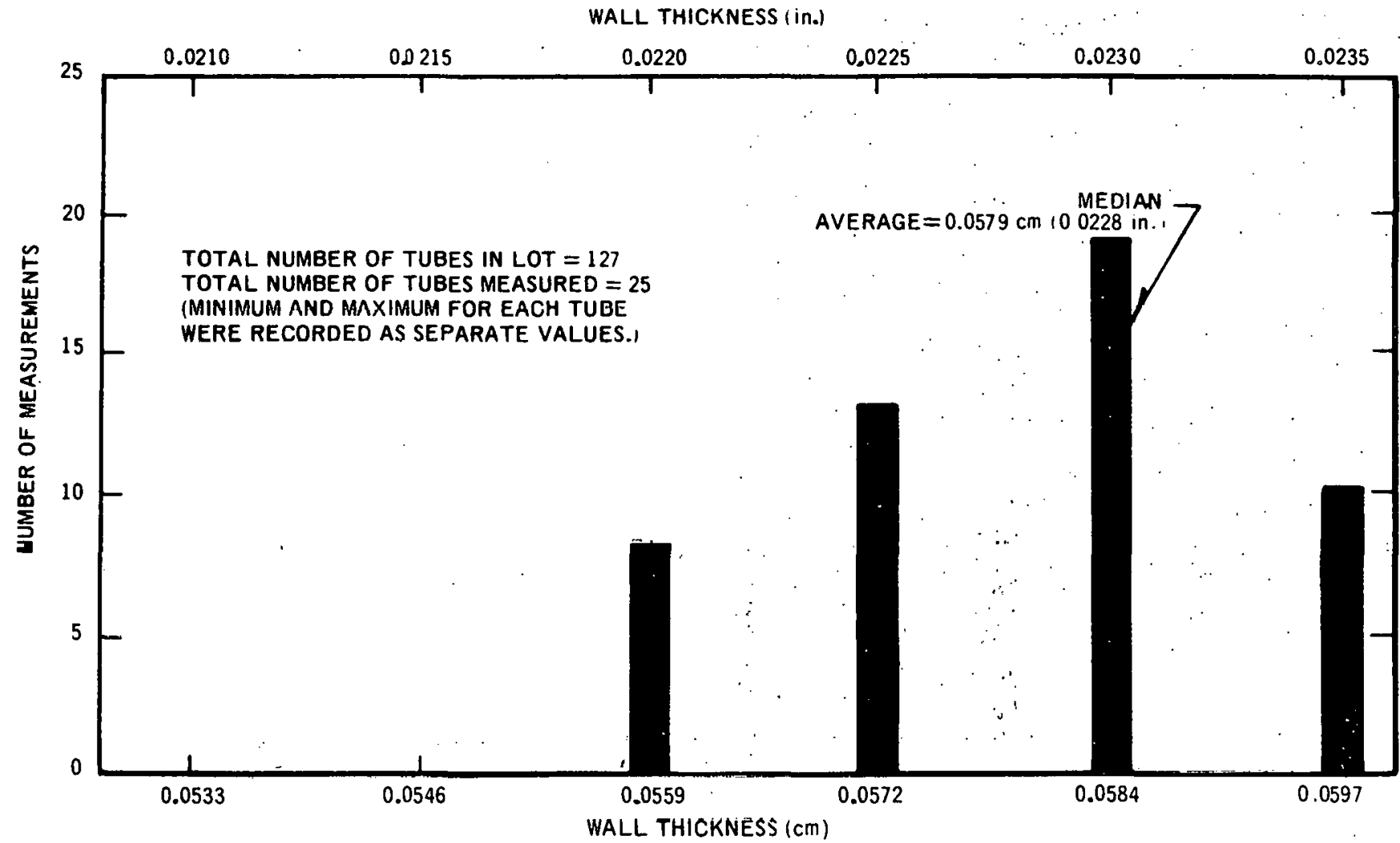

Figure B:5. Wall Thickness Measurements on Sample Tubes From Lot CA-2 


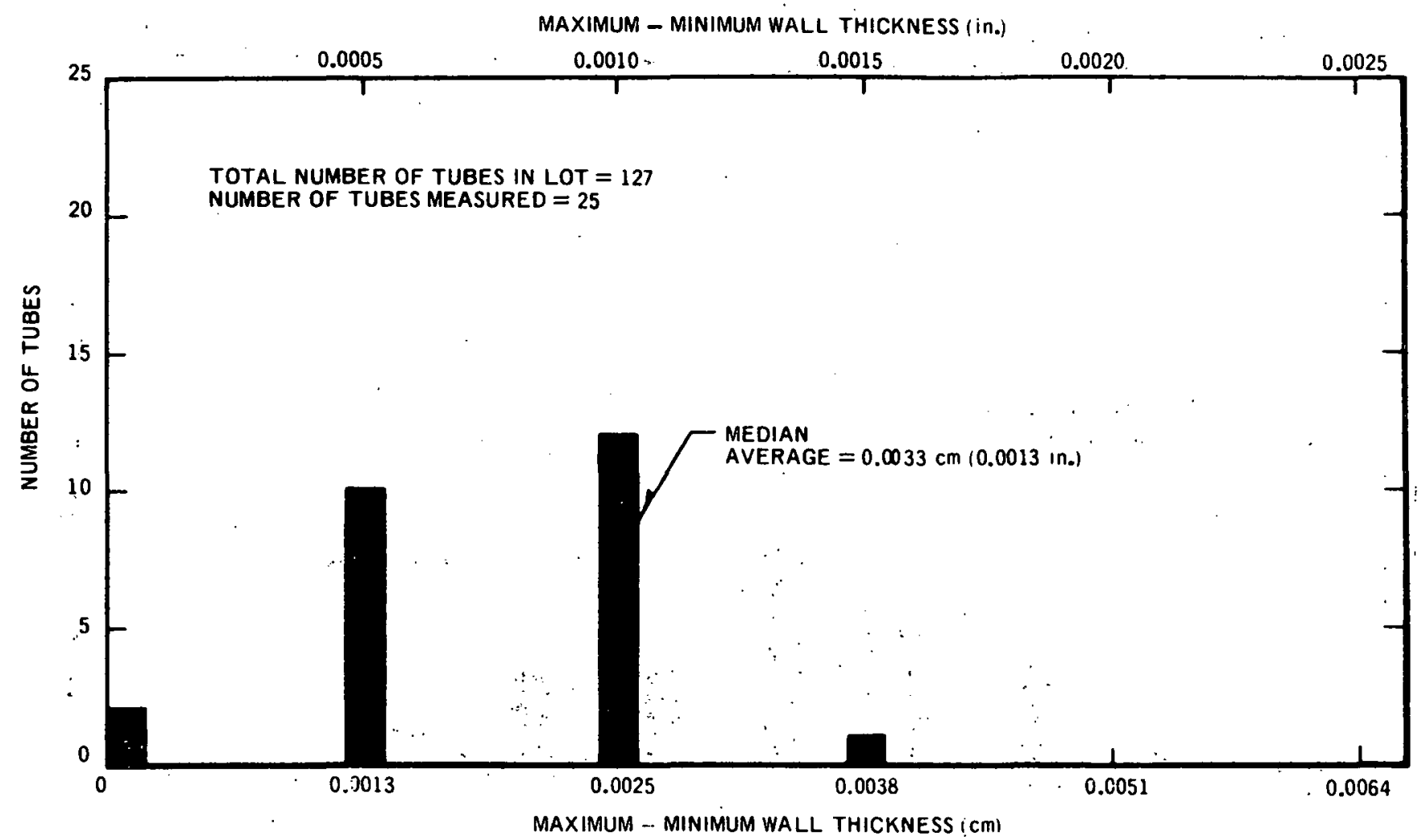

Figure B-6. Difference in Maximum and Minimum Wall Thickness Measurements on Individual Sample Tubes From Lot CA.2

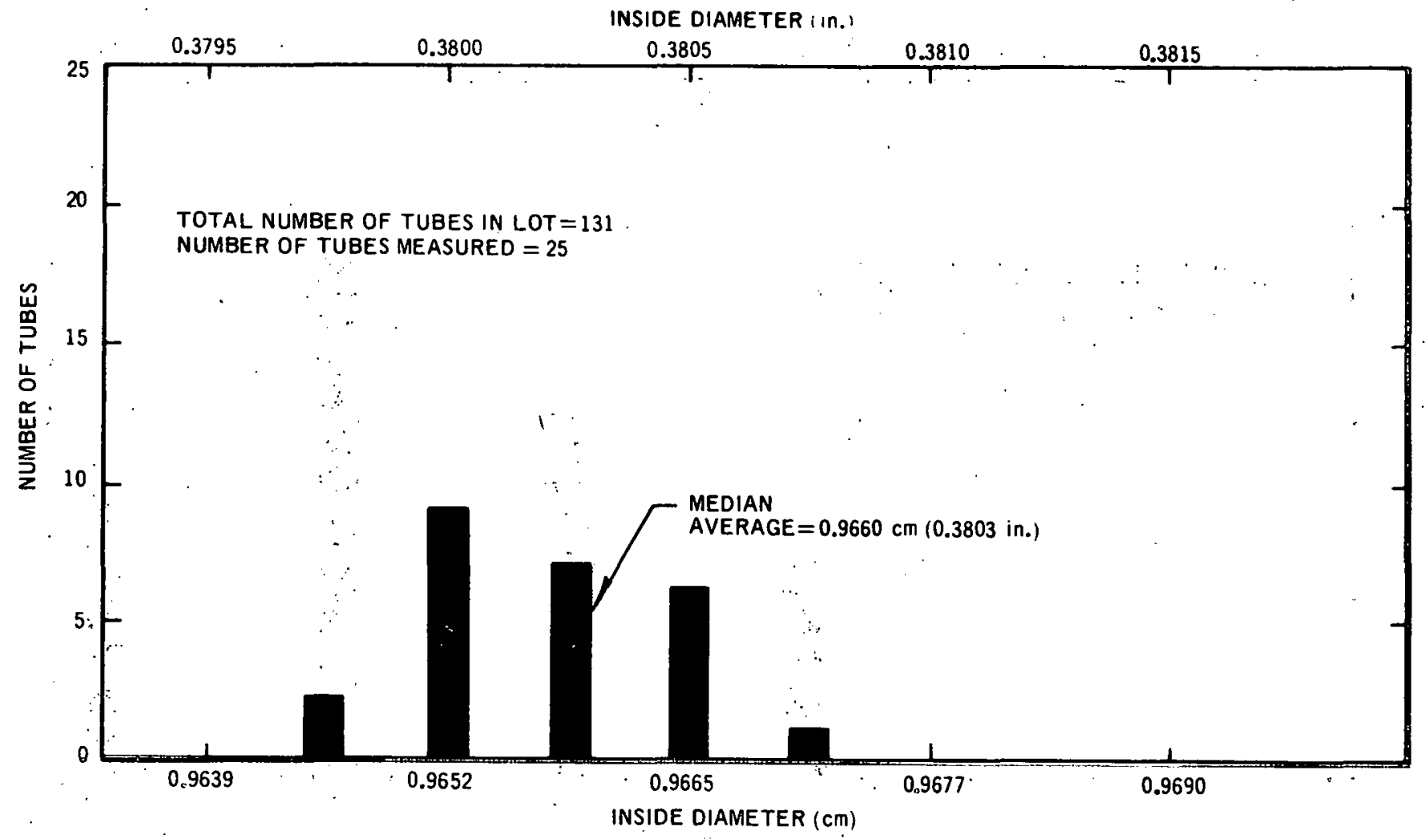

Figure B-7. Inside Diameter Measurements on Sample Tubes From Lot CA-3 


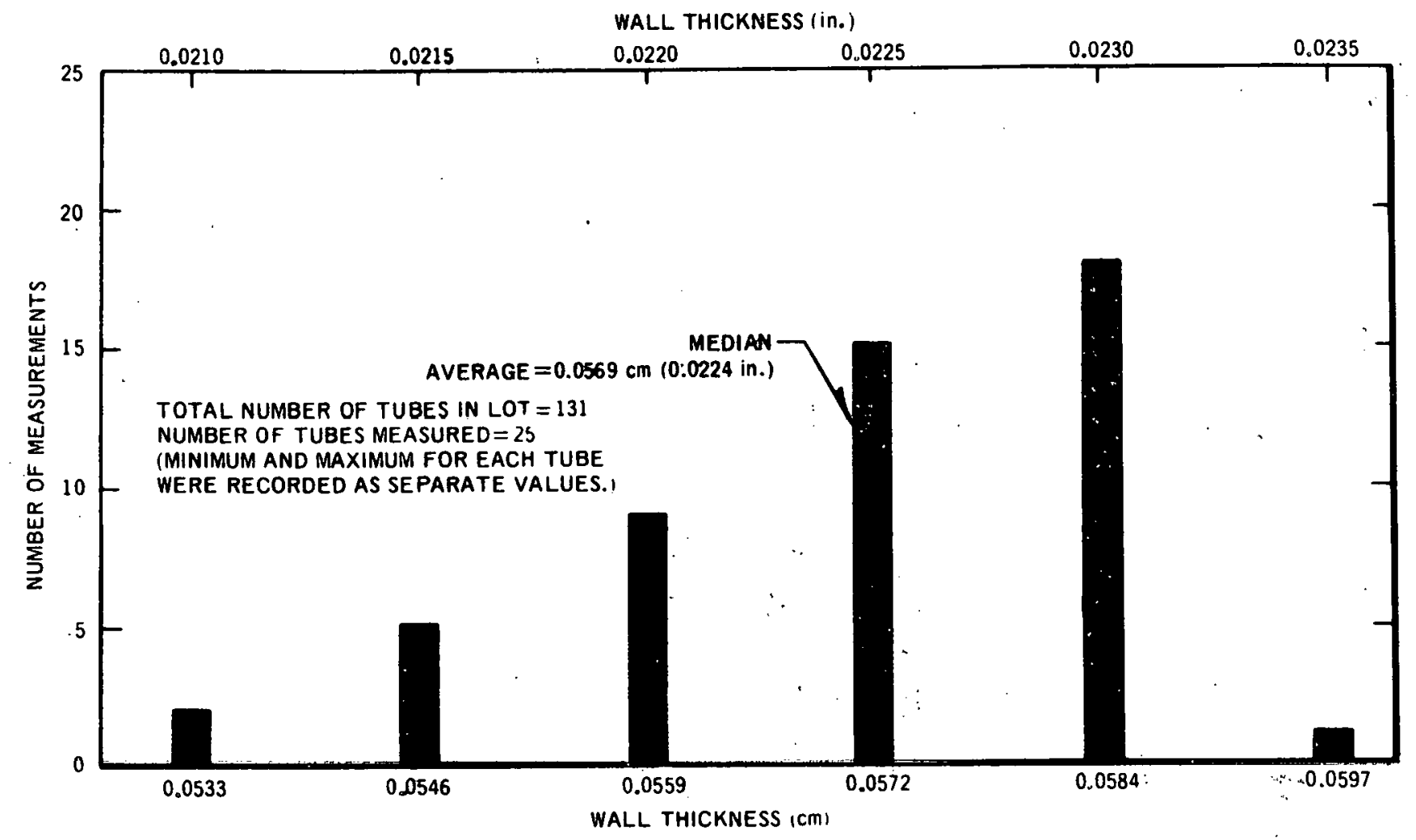

Figure B-8. Wall Thickness Measurements on Sample Tubes From Lot CA-3

MAXIMUVIV - MINIMUM WALL THICHNESS I11.

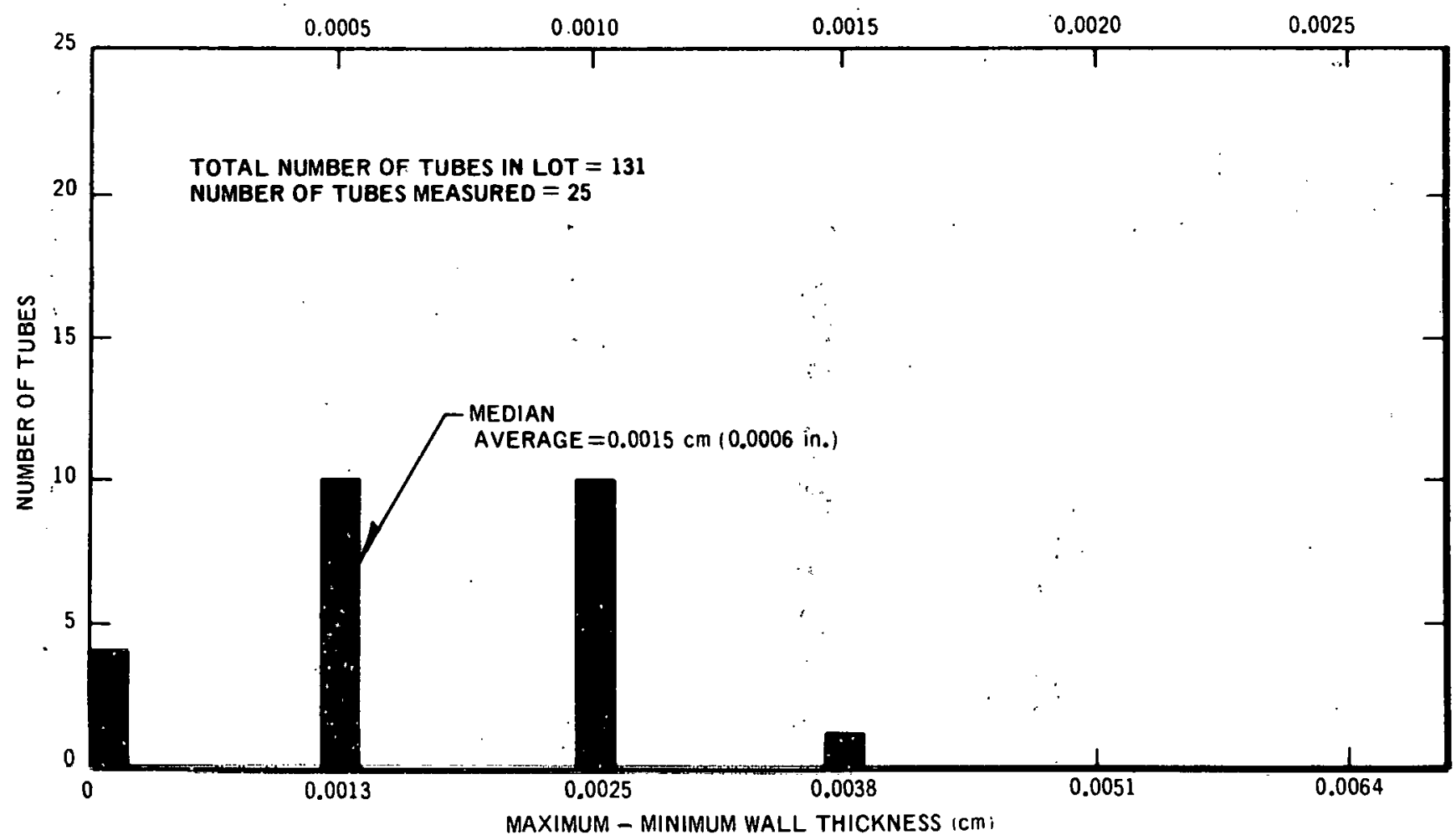

Figure B-9. Difference in Maximum and Minimum Wall Thickness Measurements on Individual Sample Tubes From Lot CA-3 
INSIDE DIAMETER (In)

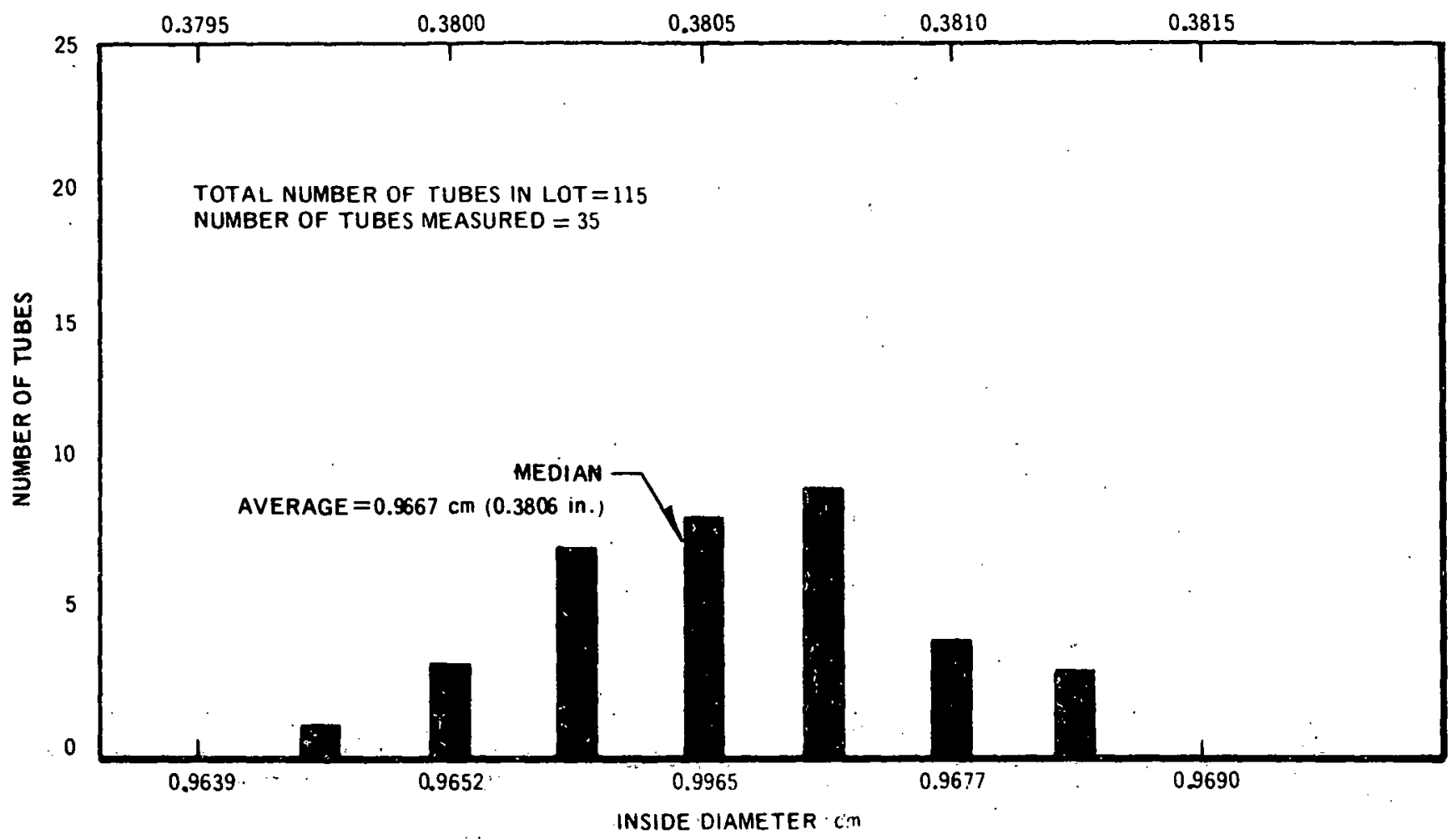

Figure'B-10. Inside Diameter Measurements on Sample Tubes From Lot CA.4

WALL THICKNESS , In.:

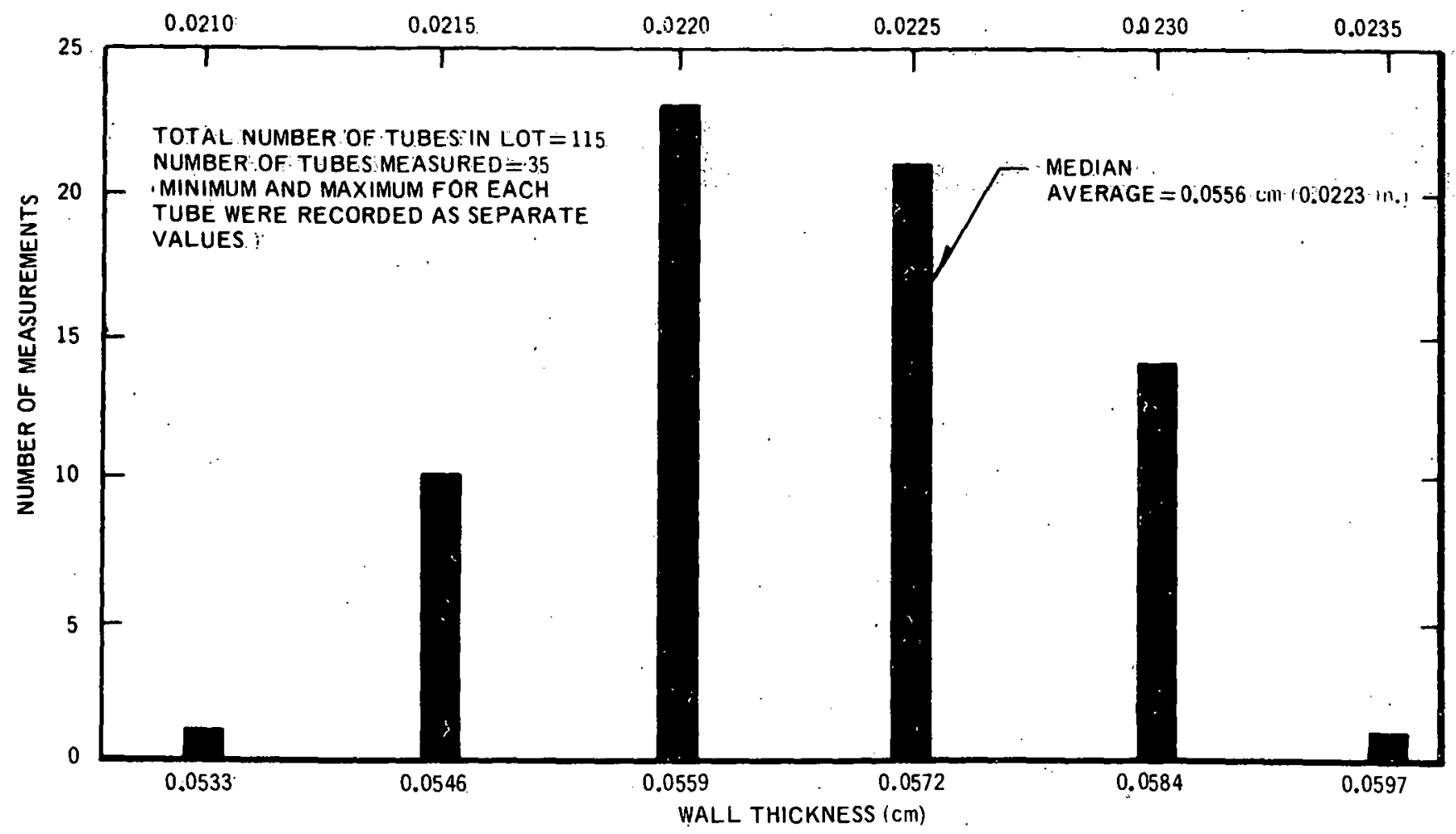

Figure B-11. Wall Thickness Measurements on Sample Tubes From Lot CA-4 


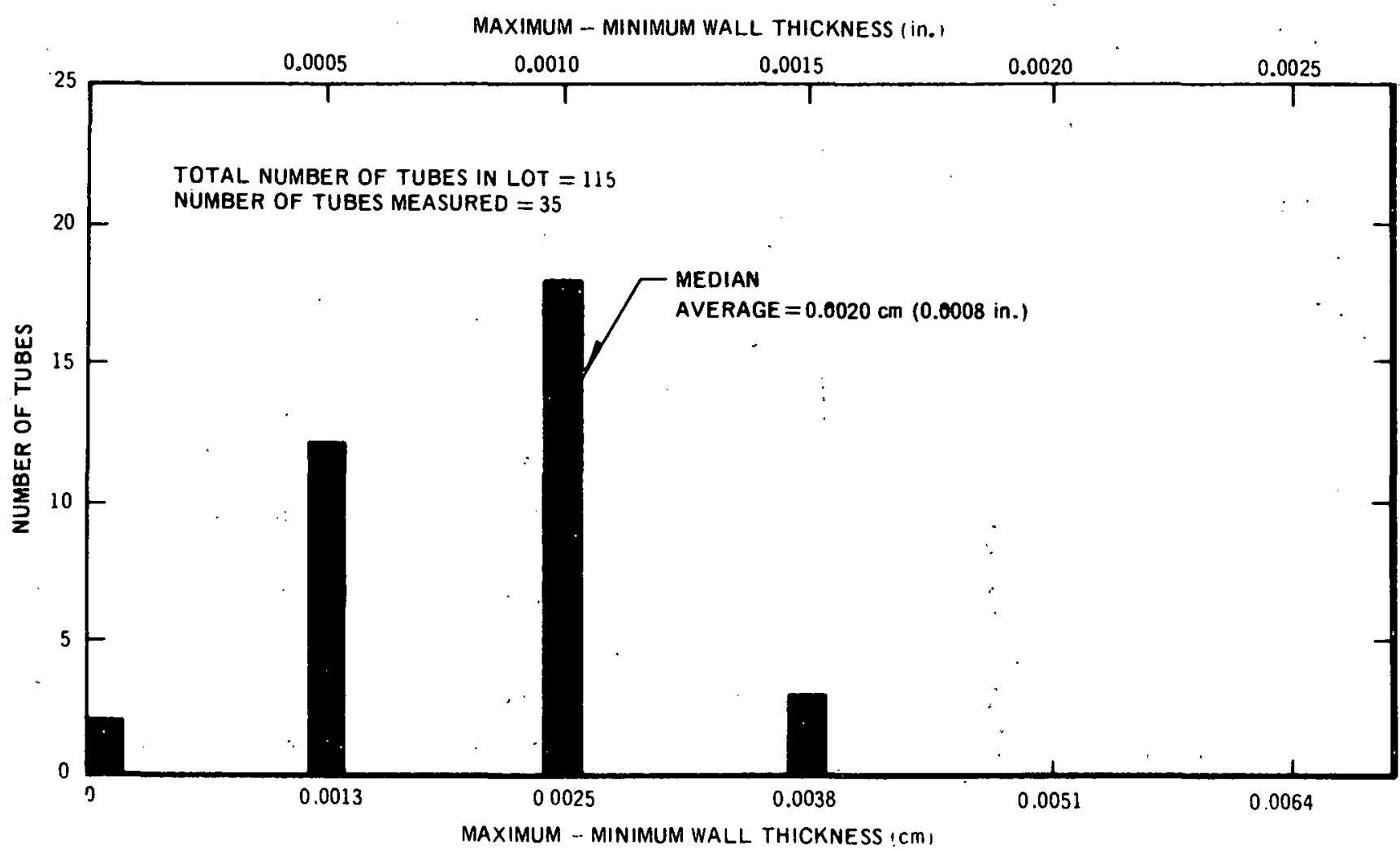

Figure B-12. Difference in Maximum and Minimum Wall Thickness Measurements on Individual Sample Tubes Fróm Lot CA-4 INSIDE DIAMETER (In.)

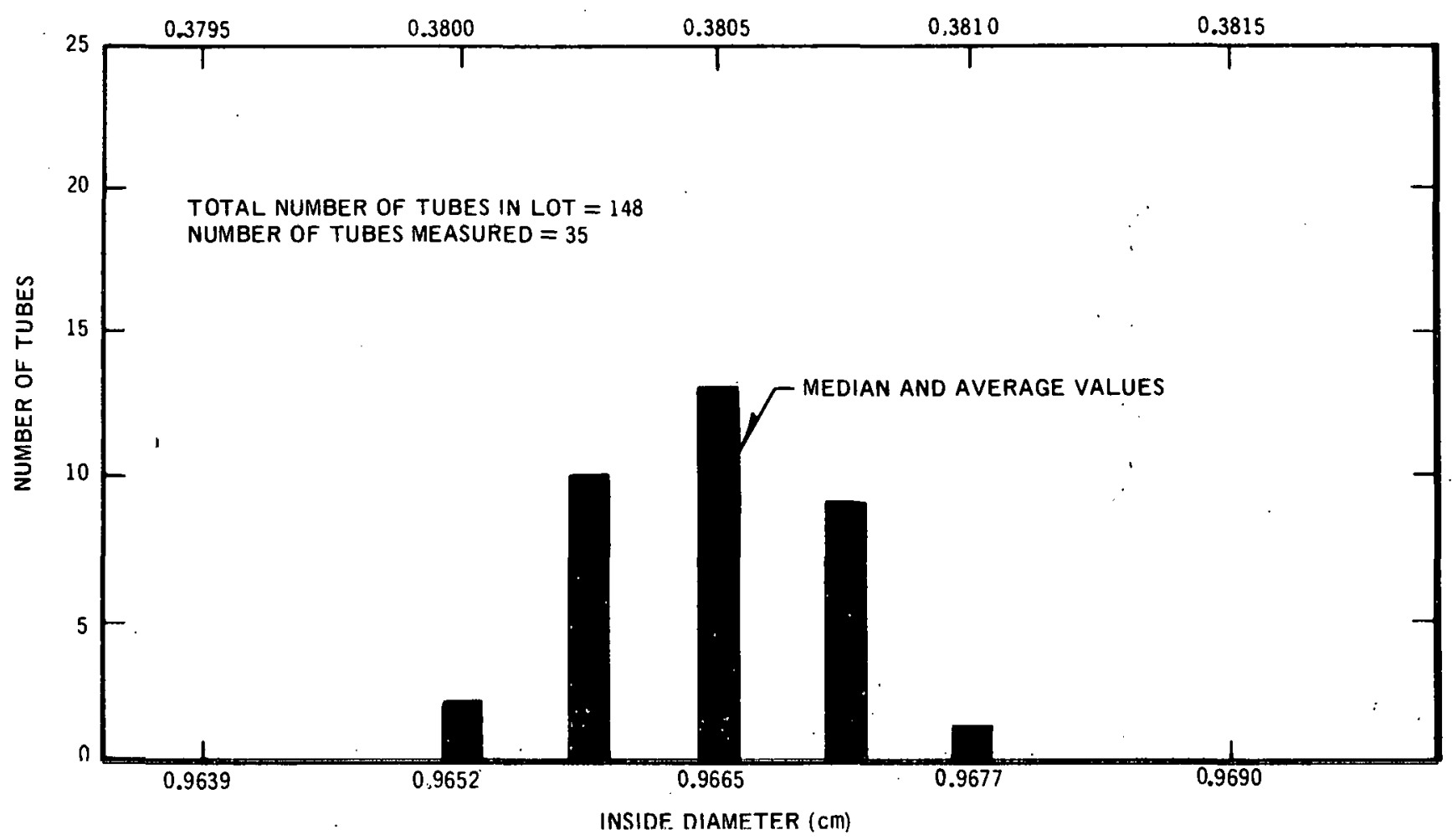

Figure B-13. Inside Diameter Measurements on Sample Tubes Frorn Lot CA-5 
WALL THICKNESS ( 1 n.)

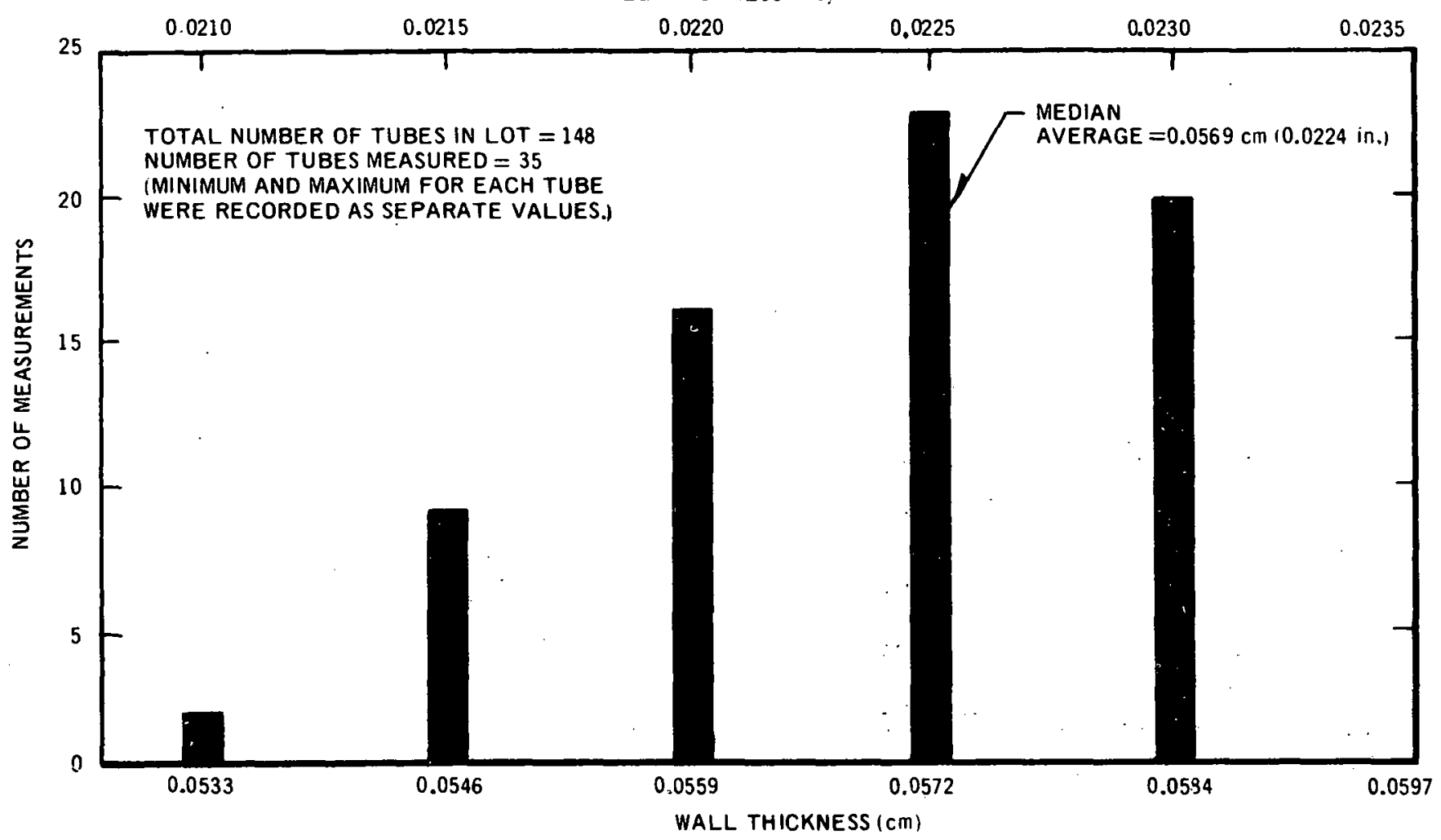

Figure B-14. Wall Thickness Measurements on Sample Tubes From Lot CA.5

MAXIMUM - MINIMUM WALL THICKNESS (in.)

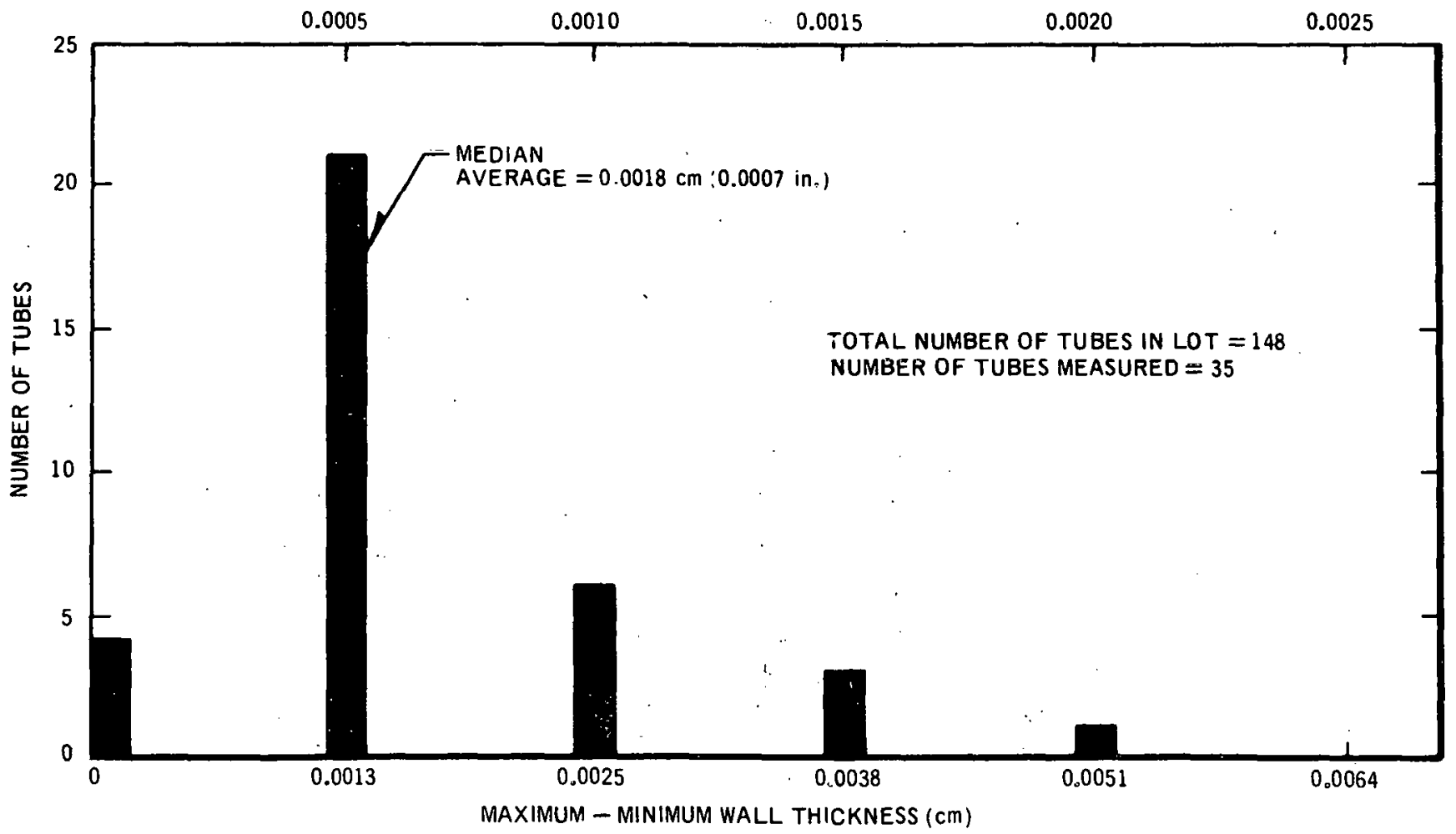

Figure B-15. Difference in Maximum and Minimum Wall Thickness Measurements on Individual Sample Tubes From Lot CA-5 
APPENDIX C

DIAMETERS OF INDIVIDUALLY MEASURED PELLETS IN SIX RODS ACCORDING TO FUEL COLUMN POSITION

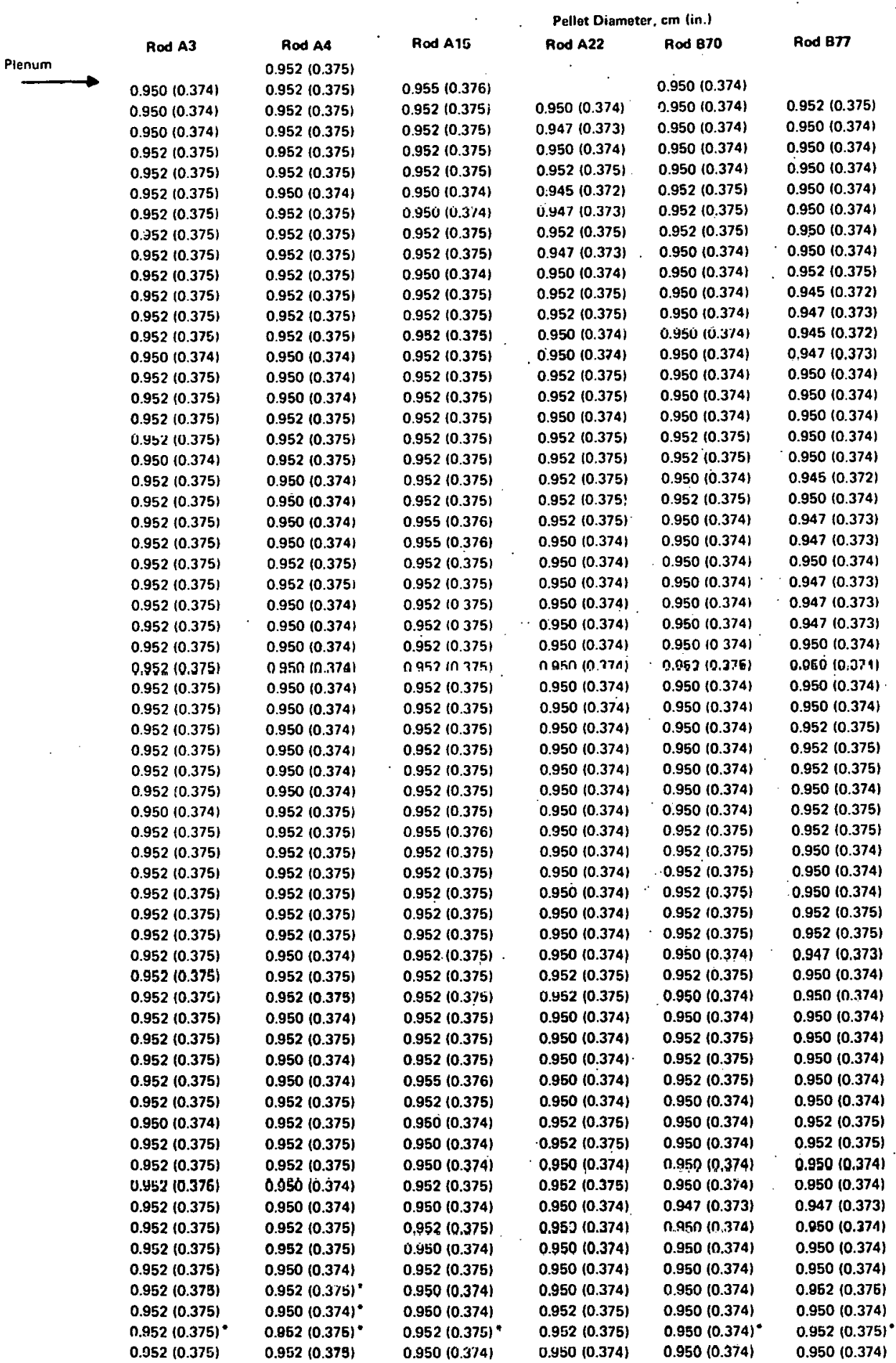

Short

End P!ug

- Denoteg $0.6 \mathrm{~cm}(1 / 4 \cdot \mathrm{in}$.$) long spacer' pellet.$ 


\section{REFERENCES}

1. Baroch, C. J., Hoffmann, J. P., and Rous, W. C., AEC Fuel Cycle Program - Design and Fabrication of the Basic Fuel Assemblies, March 15, 1963.(GEAP-3653).

2. Williamson, H. E., Baroch, C. J., Hoffmann, J.P., and Ikeuye, D. T., AEC Fuel Cycle Program - Examination of Zircalov-Clad $\mathrm{UO}_{2}$ Fuel Rods Operated in the VBWR to 10,000 MWd/tU, March 15, 1965 (GEAP.4597).

3. Timoshenko, S., Strength of Materials, Part II, Third Edition, D. Van Nostrand Company, 1956.

4. Lustman, B., and Kerze. F., The Metallurgy of Zirconium; McGraw-Hill Book Company, Inc., 1955.

5. Spalaris, C. N., and Mangrum, E., Jr., N. S. Savannah Fuel Design and Development Program - Fuel Element Internal Pressure Considerations, Savannah Core II. June 20, 1960 (GEAP-3381).

6. Baroch, C. J., Hoffmann, J. P., Williamson, H. E., and Pashos, T. J., Comparative Performance of Zircaloy and Stainless Stecl Clad Fuel Rods Operated to 10,000 MWd/t in the VBWR. April 1966 (GEAP-4849).

\section{ACKNOWLEDGMENTS}

The SA-1 fuel rods were designed, fabricated, received their initial irradiation, and were examined at the end of VBWR operation under the AEC Fuel Cycle Program (Contract AT (04-3)-189, Project Agreement 11). The remaining components of the SA-1 assembly were designed, fabricated, loaded with rods, transported to Dresden, and site assembled (all in a minimum of time) as a GE-sponsored project under the direction of H.E. Williamson. Some of the major contributors to the latter task were J. P. Hoffmann (assembly design and fabrication). J. S. Atkinson (auxiliary equipment design and fabrication, assembly fabrication), J. Vaupel (assembly design), P. W. Mathay (hot cell operations), D. R. Nelson (thermal-hydraulics analysis), E. L. Strickland (physics analysis), and W. Foote (transportation). 


\section{DISTRIBUTION}

Atomic Energy Commission

San Francisco Operations Office

2111 Bancroft Way

Berkeley, California 94704

Arthur W. Larson

Site Representative

U.S. Atomic Energy Commission

c/o General Electric Company

310 DeGuigne Avenue

Sunnyvale, California 94086

U.S. Atomic Energy Commission

Germantown, Maryland 20545 .

Attn: J.M. Simmons

U.S. Atomic Energy Commission

Germantown, Maryland 20545

Attn: A. Van Echo

U.S. Atornic Energy Commission

Germantown, Maryland 20545

Attn: J.A. Lieberman

U.S. Atomic Energy Commission

Germantown, Maryland 20545

Attn: S.A. Szawlewicz

U.S. Atomic Energy Commission :... Germantown, Maryland 20545

Attn: M.A. Rosen

U.S. Atünic Energy Commišsion

Germantown. Maryland 20545

Attn: E.E. Kintner

U.S. Atomic Energy Commission

Germantown, Maryland 20545

Attn: D.E. Erb

U.S. Atomic Energy Commission

Germantown, Maryland 20545

Attn: W.H. McVey

U.S. Atumic Energy Commission

Germentown, Maryland 20545

Attn: I.F. Zartman

U.S. Atomic Energy Commission

Germantown, Maryland 20545

Attn: J.W. Vaughan

U.S. Atomic Energy Commission

Germantown, Maryland 20545

Attn: Document Library

U.S. Atomic Energy Commission

Chicago Operations Office

9800 South Cass Avenue

Argonne, Illinois

Attn: M.E. Jackson, Senior Site Representative, ANL
3 U.S. Atomic Energy Commission

Oak Ridge Operations Office

Post Office Box E

Oak Ridge, Tennessee 37830

Attn: D.F. Cope, Senior Site Representative, ORNL

U.S. Atomic Energy Commission

Richland Operations Office

Richland, Washington

Attn: P.G. Holsted, Senior Site Representative, PNL

U.S. Atomic Energy Commission

2 Department of Technical Information Extension

Oak Ridge Operations Office

P.O. Box E

Oak Ridge, Tennessee 37830

1 Attn: R.L. Shannon

U.S. Atomic Energy Commission

1 P.O. Box 8

Aiken, South Carolina 29801

Attn: N. Stetson

1 Ames Laboratory

lowa State University

Box 1129 ISU Station

Ames, lowa 50010

1 Attn: F.H. Spedding

Ames Laboratory

Inwa State Univercity

1 Box 1129 ISU Station

Ames, lowa 50010

Attn: O.N. Carison

2 Ames Laboratory

lowa State University

Box 1129 ISU Station

Ames, lowa 50010

1 Attn: W.L. Larsen

Argonne National Laboratory

Argonne, Illinois 60440

Attn: R.C. Vogel

Argonne National Laboratory

29700 South Cass Avenue

Argonne, Illinois 60440

Attn: M.V. Nevitt

1 Argonne National Laboratory

9700 South Cass Avenue

Argonne, Illinois 60440

Attn: J.H. Kittel

1

Brookhaven National Laboratory

Upton, New York 11973

Attn: D.H. Gurinsky 
Los Alamos Scientific Laboratory P.O. Box 1663

Los Alamos, New Mexico 87544

Attn: D.E. Hall

Los Alamos Scientific Laboratory P.O. Box 1663

Los Alamos, New Mexico 87544

Attn: R.D. Baker

Oak Ridge National Laboratory

Oak Ridge Operations Office

P.O. Box E

Oak Ridge, Tennessee 37830

Attn: J.E. Cunningham

Oak Ridge National Laboratory

Oak Ridge Operations Office

P.O. Box E

Oak Ridge. Tennessee 37830

Attn: P. Patriarca

Oak Ridge National Laboratory

Oak Ridge Operations Office

P.O. Box E

Oak Ridge, Tennessee 37830

Attn: D.E. Ferguson

Oak Ridge National Laboratory

Oak Ridge Operations Office

P.O. Box E

Oak Ridge, Tennessee 37830

Attn: J.R. Weir

Pacific Norihwest Laboratory

P.O. Box 999

Richland, Washington 99352

Attn: F.W. Albaugh

Pacific Northwest Laboratory

P.O. Box 999

Richland, Washington 99352

Attn: J.J. Cadwel!

Pacific Northwest Laboratory

P.O. Box 999

Richland, Washington 99352

Attn: A.L. Bement

Pacific Northwest Laboratory P.O. Box 999

Richland, Washington 99352

Attn: E. Evans

Pacific Northwest Laboratory P.O. Box 999

Richland, Washington 99352

Attn: R.L. Dillon

Pacific Northwest Laboratory P.O. Box 999

Richland, Washington 99352

Attn: R.G. Wheeler
1 Atomics International

P.O. Box 301

Canoga Park, California 91304

Attn: S. Carniglia

1. Atomics International

P.O. Box 301

Canoga Park, California 91304

Attn: S. Arneson

2 Battelle Memorial Institute

505 King Avenue

Columbus, Ohio 43201

Attn: S. Paprocki

Battelle Memorial Institute

1505 King Avenue

Columbus, Ohio 43201

Attn: D. Keller

Battelle Memorial Institute 505 King Avenue

1 Columbus, Ohio 43201

Attn: W. Berry

Battelle Memorial Institute 505 King Avenue

Columbus, Ohio 43201

Attn: DMIC

Babcock \& Wilcox Company P.O. Box 1260

Lynchburg, Va. 24505

Attn: C. Baroch

Bobcock \& Wilcox Company

P.O. Box 1260

Lynchbury, Va. 24505

Attn: L. Weissert

Babcock \& Wilcox Company P.O. Box 1260

Lynchburg, Va. 24505

Attn: J. Landis

Babcock \& Wilcox Company P.O. Box 1260

1 Lynchburg, Va. 24505

Attn: C. Johnson

Combustion Engineering, Inc. Naval Reactors Division

P.O. Box 400

$1 \quad$ Windsor, Connecticut 06095

Attn: W.P. Chernock

Combustion Engineering, Inc. Naval Reactors Division

1 P.O. Box 400

Windsor, Connecticut 06095

Attn: S.S. Christopher

Gulf General Atomics, Inc.

P.O. Box 608

San Diego, California 92112

Attn: S. Jaye 
General Electric Company KAPL

One River Road

Schenectady, N.Y.

Attn: A.E. Bibb

General Electric Company NMPO

P.O. Box 132

Cincinnati, Ohio 45215

Attn: V.P. Calkins

General Electric Company NMPO

P.O. Box 132

Cincinnati, Ohio 45215

Attn: C. Brassfield

General Electric Company NMPO

P.O. Box 132

Cincinnati, Ohio 45215

Attn: J. McGurty

Savannah River Laboratory-du Pont E.I. du Pont de Nemours \& Co.

Savannah River Plant

Aiken, South Carolina 29801

Attn: TIS Document Room

Savannah River Laboratory -du Pont E.I. du Pont de Nemours \& Co. Savannah River Plant

Aiken, South Carolina 29801

Attn: R.R. Marshall

Westinghouse Electric Corporation APD

P.O. Box 355

Pittsburgh, Pa. 15230

Attn: T. Stern
1 Westinghouse Electric Corporation

P.O. Box 79

West Mifflin, Pa. 15122

Attn: E.J. Kreigh

1

Westinghouse Electric Corporation Bettis Atomic Power Plant

P.O. Box 79

West Mifflin, Pa. 15122

Attn: R.H. Fillnow

Westinghouse Electric Corporation Bettis Atomic Power Plant

P.O. Box 79

West Mifflin, Pa. 15122

1 Attn: B. Lustman

Westinghouse Electric Corporation

Bettis Atomic Power Plant

P.O. Box 79

1 West Mifflin. Pa. 15122

Attn: W. J. Babyak

Idaho Nuclear Corporation

1

P.O. Box 1845

Idaho Falls, Idaho 83401

1 Attn: J.M. Beeston

Idaho Nuclear Corporation

Idaho Falls, Idaho 83401

Attn: W. C. Francis

2

United Nuclear Library 